Prepared in cooperation with Utah State University and Northern Arizona University

\title{
Monitoring and Research to Describe Geomorphic Effects of the 2011 Controlled Flood on the Green River in the Canyon of Lodore, Dinosaur National Monument, Colorado and Utah
}

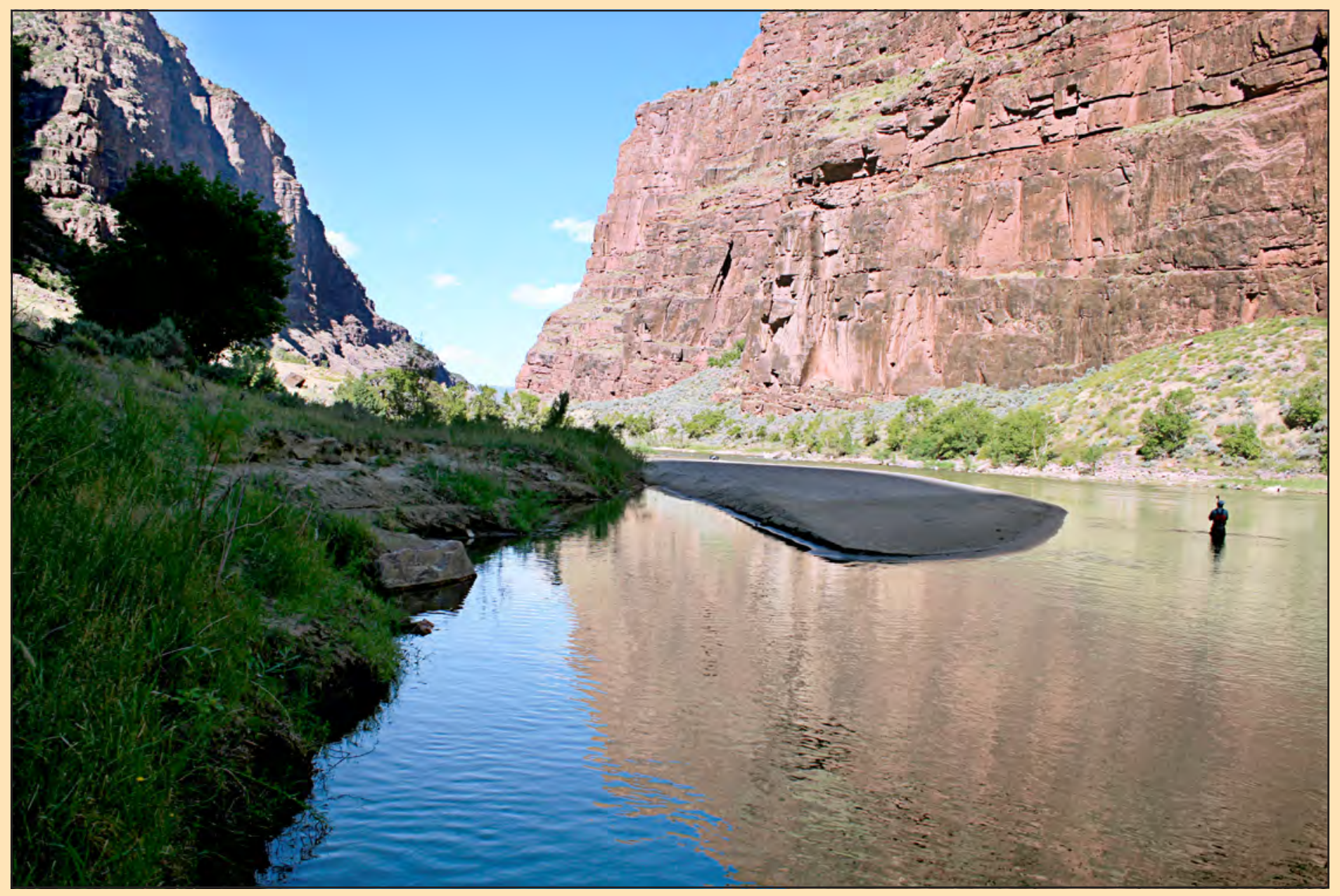

Scientific Investigations Report 2014-5022 

Ted Melis). 


\section{Monitoring and Research to Describe Geomorphic Effects of the 2011 Controlled Flood on the Green River in the Canyon of Lodore, Dinosaur National Monument, Colorado and Utah}

By Erich R. Mueller, Paul E. Grams, John C. Schmidt, Joseph E. Hazel, Jr., Matt Kaplinski, Jason A. Alexander, and Keith Kohl

Prepared in cooperation with Utah State University and Northern Arizona University

Scientific Investigations Report 2014-5022 


\title{
U.S. Department of the Interior SALLY JEWELL, Secretary
}

\section{U.S. Geological Survey \\ Suzette M. Kimball, Acting Director}

\author{
U.S. Geological Survey, Reston, Virginia: 2014
}

For more information on the USGS - the Federal source for science about the Earth, its natural and living resources, natural hazards, and the environment, visit http://www.usgs.gov or call 1-888-ASK-USGS.

For an overview of USGS information products, including maps, imagery, and publications, visit http://www.usgs.gov/pubprod

To order this and other USGS information products, visit http://store.usgs.gov

Any use of trade, firm, or product names is for descriptive purposes only and does not imply endorsement by the U.S. Government.

Although this information product, for the most part, is in the public domain, it also may contain copyrighted materials as noted in the text. Permission to reproduce copyrighted items must be secured from the copyright owner.

Suggested citation:

Mueller, E.R., Grams, P.E., Schmidt, J.C., Hazel, J.E., Jr., Kaplinski, M., Alexander, J.A., and Kohl, K., 2014, Monitoring and research to describe geomorphic effects of the 2011 controlled flood on the Green River in the Canyon of Lodore, Dinosaur National Monument, Colorado and Utah: U.S. Geological Survey Scientific Investigations Report 2014-5022, 66 p., http://dx.doi.org/10.3133/sir20145022.

ISSN 2328-0328 (online) 


\section{Contents}

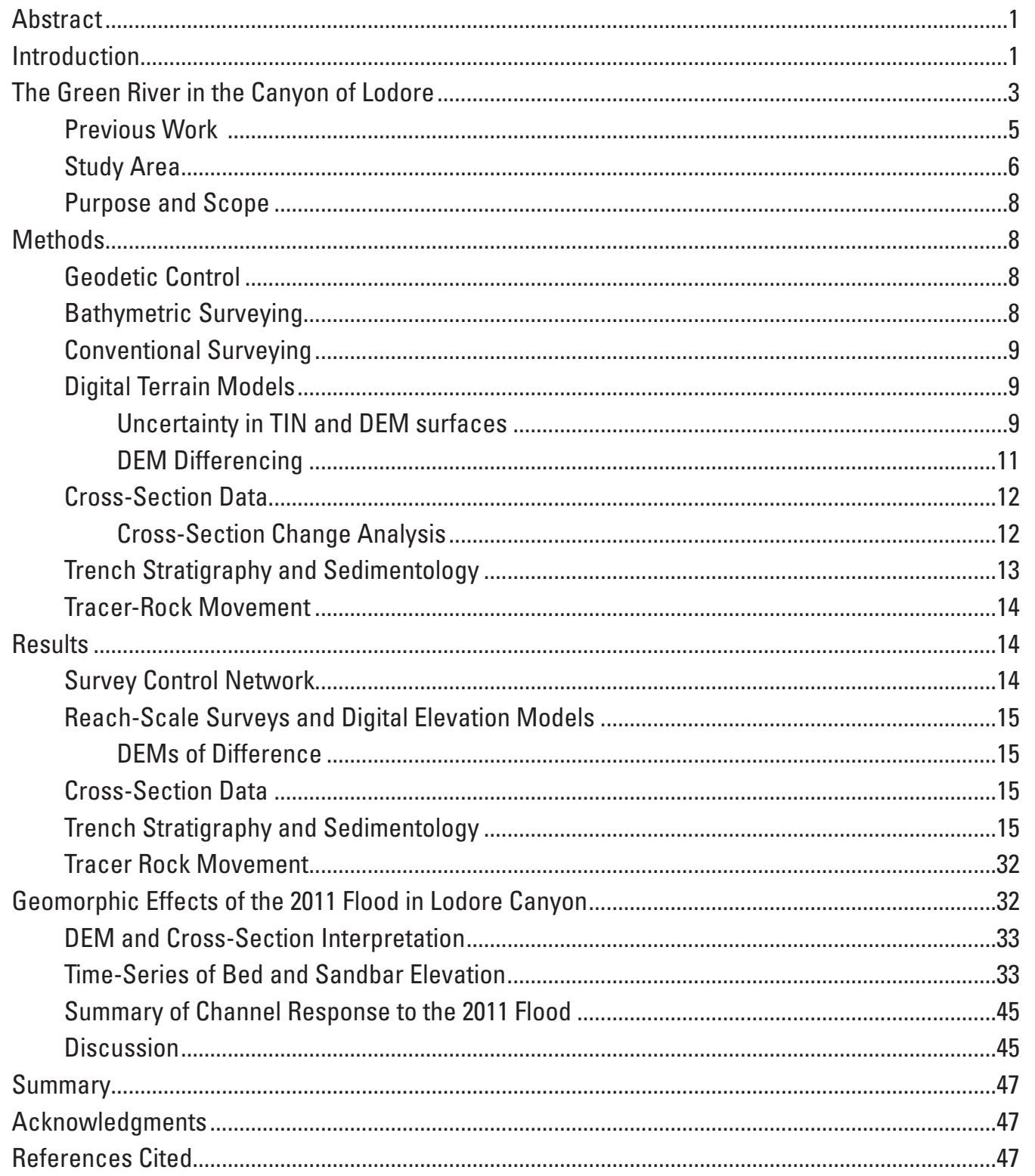

\section{Appendixes}

1. Surficial Geology and Geomorphic Surfaces Mapped for the Study Reaches .......................52

2. Trench Stratigraphy Data [available as a .xlsx file only online at http://pubs.usgs.gov/sir/2014/5022/ ..........................................................................62

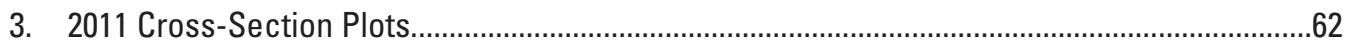




\section{Figures}

1. Map of study area showing location of the Canyon of Lodore within

Dinosaur National Monument, Colorado .......................................................................

2. Graphs of discharge for the Green River near Greendale, Utah ................................................

3. Graph showing mean daily discharge of the Green River near Greendale, Utah, from 1950 to 2012

4. Diagram showing geomorphic levels relative to the stage of a typical post-dam flood for the Green River downstream from Flaming Gorge Dam, Colorado and Utah. .6

5. Field photographs from the Canyon of Lodore, Dinosaur National Monument, Colorado and Utah...... 10

6. Diagram illustrating methods used to calculate changes in cross-section area and bed elevation at monumented cross sections based on repeated surveys of the Green River in the Canyon of Lodore, Dinosaur National Monument, Colorado and Utah.

7. Map/aerial image of survey control network for the Wade and Curtis and Winnies reaches on the Green River in Canyon of Lodore, Dinosaur National Monument, Colorado and Utah.

8. Map/aerial image of survey control network for the RM233 and Triplet reaches on the Green River in Canyon of Lodore, Dinosaur National Monument, Colorado and Utah.

9. Maps/aerial images of the Wade and Curtis reach on the Green River in Canyon of Lodore, Dinosaur National Monument, Colorado and Utah...

10. Maps/aerial images of Winnies reach on the Green River in Canyon of Lodore, Dinosaur National Monument, Colorado and Utah.

11. Maps/aerial images of the RM233 reach on the Green River in Canyon of Lodore, Dinosaur National Monument, Colorado and Utah.

12. Maps/aerial images of the Triplet reach on the Green River in Canyon of Lodore, Dinosaur National Monument, Colorado and Utah.

13. Maps/aerial images of geomorphic change between 2001 and 2011 surveys for the Wade and Curtis reach and Winnies reach on the Green River in Canyon of Lodore, Dinosaur National Monument, Colorado and Utah

14. Maps/aerial images of geomorphic change between 2001 and 2011 surveys for the RM233 reach and the Triplet reach on the Green River in Canyon of Lodore, Dinosaur National Monument, Colorado and Utah...

15. Maps/aerial images of locations of trenches and painted tracer rock sites for the Wade and Curtis and Winnies reaches and for the RM233 and Triplet reaches on the Green River in Canyon of Lodore, Dinosaur National Monument, Colorado and Utah.

16. Schematic representations of the trench stratigraphy on the Green River in Canyon of Lodore, Dinosaur National Monument, Colorado and Utah ...

17. Graphs of channel change at select cross sections for the Wade and Curtis reach on the Green River in Canyon of Lodore, Dinosaur National Monument, Colorado and Utah. 
18. Graphs of channel change at select cross sections for Winnies reach on the Green River in Canyon of Lodore, Dinosaur National Monument, Colorado and Utah.

19. Graphs of channel change at select cross sections for the RM233 reach on the Green River in Canyon of Lodore, Dinosaur National Monument, Colorado and Utah.

20. Graphs of channel change at select cross sections for the Triplet reach on the Green River in Canyon of Lodore, Dinosaur National Monument, Colorado and Utah

21. Graphs of change in average elevation for sandbars in the flood zone, fluctuating flow zone, and main channel bed of the Green River in Canyon of Lodore, Dinosaur National Monument, Colorado and Utah

22. Graphs of change in average elevation for sandbars in the flood zone, fluctuating flow zone, and main channel bed of the Green River in Canyon of Lodore, Dinosaur National Monument, Colorado and Utah

23. Graphs of change in average area for sandbars in the flood zone, fluctuating flow zone, and main channel bed of the Green River in Canyon of Lodore, Dinosaur National Monument, Colorado and Utah

1-1. Maps of primary depositional environments and geomorphic surface levels for the Wade and Curtis reach, Canyon of Lodore, Dinosaur National Monument, Colorado and Utah...

1-2. Maps of primary depositional environments and geomorphic surface levels for the Winnies reach, Canyon of Lodore, Dinosaur National Monument, Colorado and Utah.

1-3. Maps of primary depositional environments and geomorphic surface levels for the RM233 reach, Canyon of Lodore, Dinosaur National Monument, Colorado and Utah.

1-4. Maps of primary depositional environments and geomorphic surface levels for the Triplet reach, Canyon of Lodore, Dinosaur National Monument, Colorado and Utah

3-1 Long-term monitoring cross-sections extracted from the 2011 digital terrain models for the Wade and Curtis reach, Canyon of Lodore, Dinosaur National Monument, Colorado and Utah

3-2 Long-term monitoring cross-sections extracted from the 2011 digital terrain models for the Winnies reach, Canyon of Lodore, Dinosaur National Monument, Colorado and Utah

3-3 Long-term monitoring cross-sections extracted from the 2011 digital terrain models for the RM233 reach, Canyon of Lodore, Dinosaur National Monument, Colorado and Utah

3-4 Long-term monitoring cross-sections extracted from the 2011 digital terrain models for the Triplet reach, Canyon of Lodore, Dinosaur National Monument, Colorado and Utah 


\section{Tables}

1. Dates and locations for cross-section surveys used in geomorphic change analysis on the Green River in the Canyon of Lodore, Dinosaur National Monument, Colorado and Utah

2. Data collection at each reach on the Green River during the 2011 field campaign in the Canyon of Lodore, Dinosaur National Monument, Colorado and Utah

3. Locations of control network benchmarks on the Green River in Canyon of Lodore, Dinosaur National Monument, Colorado and Utah

4. Results from tracer rock analysis from the Green River in Canyon of Lodore, Dinosaur National Monument, Colorado and Utah 


\section{Conversion Factors}

Inch/Pound to SI

\begin{tabular}{|c|c|c|}
\hline Multiply & By & To obtain \\
\hline \multicolumn{3}{|c|}{ Length } \\
\hline inch (in.) & 25.4 & millimeter (mm) \\
\hline inch (in.) & 2.54 & centimeter (cm) \\
\hline foot $(\mathrm{ft})$ & 0.3048 & meter (m) \\
\hline mile (mi) & 1.609 & kilometer (km) \\
\hline \multicolumn{3}{|c|}{ Area } \\
\hline square foot $\left(\mathrm{ft}^{2}\right)$ & 0.09290 & square meter $\left(\mathrm{m}^{2}\right)$ \\
\hline square mile $\left(\mathrm{mi}^{2}\right)$ & 2.590 & square kilometer $\left(\mathrm{km}^{2}\right)$ \\
\hline \multicolumn{3}{|c|}{ Flow rate } \\
\hline cubic foot per second $\left(\mathrm{ft}^{3} / \mathrm{s}\right)$ & 0.02832 & cubic meter per second $\left(\mathrm{m}^{3} / \mathrm{s}\right)$ \\
\hline \multicolumn{3}{|l|}{ SI to Inch/Pound } \\
\hline $\begin{aligned} \text { Multiply } \\
\end{aligned}$ & By & To obtain \\
\hline \multicolumn{3}{|c|}{ Length } \\
\hline millimeter (mm) & 0.03937 & inch (in.) \\
\hline centimeter (cm) & 0.3937 & inch (in.) \\
\hline meter (m) & 3.281 & foot $(\mathrm{ft})$ \\
\hline kilometer (km) & 0.6214 & mile (mi) \\
\hline \multicolumn{3}{|c|}{ Area } \\
\hline square meter $\left(\mathrm{m}^{2}\right)$ & 10.76 & square foot $\left(\mathrm{ft}^{2}\right)$ \\
\hline square kilometer $\left(\mathrm{km}^{2}\right)$ & 0.3861 & square mile $\left(\mathrm{mi}^{2}\right)$ \\
\hline \multicolumn{3}{|c|}{ Flow rate } \\
\hline cubic meter per second $\left(\mathrm{m}^{3} / \mathrm{s}\right)$ & 35.31 & cubic foot per second $\left(\mathrm{ft}^{3} / \mathrm{s}\right)$ \\
\hline
\end{tabular}

Horizontal and vertical coordinate information is referenced to the North American Datum of 1983 (NAD 83(NSRS 2007)). 



\title{
Monitoring and Research to Describe Geomorphic Effects of the 2011 Controlled Flood on the Green River in the Canyon of Lodore, Dinosaur National Monument, Colorado and Utah
}

\author{
By Erich R. Mueller, ${ }^{1}$ Paul E. Grams, ${ }^{2}$ John C. Schmidt, ${ }^{2}$ Joseph E. Hazel, Jr., ${ }^{3}$ Matt Kaplinski, ${ }^{3}$ \\ Jason A. Alexander, ${ }^{2}$ and Keith Kohl'
}

\begin{abstract}
In 2011, a large magnitude flow release from Flaming Gorge Reservoir, Wyoming and Utah, occurred in response to high snowpack in the middle Rocky Mountains. This was the third highest recorded discharge along the Green River downstream of Flaming Gorge Dam, Utah, since its initial closure in November 1962 and motivated a research effort to document effects of these flows on channel morphology and sedimentology at four long-term monitoring sites within the Canyon of Lodore in Dinosaur National Monument, Colorado and Utah. Data collected in September 2011 included raft-based bathymetric surveys, ground-based surveys of banks, channel cross sections and vegetation-plot locations, sand-bar stratigraphy, and painted rock recovery on gravel bars. As part of this surveying effort, Global Navigation Satellite System (GNSS) data were collected at benchmarks on the canyon rim and along the river corridor to establish a high-resolution survey control network. This survey control network allows for the collection of repeatable spatial and elevation data necessary for high accuracy geomorphic change detection. Nearly 10,000 ground survey points and more than 20,000 bathymetric points (at 1-meter resolution) were collected over a 5-day field campaign, allowing for the construction of reach-scale digital elevation models (DEMs). Additionally, we evaluated longterm geomorphic change at these sites using repeat topographic surveys of eight monumented cross sections at each of the four sites.
\end{abstract}

\footnotetext{
${ }^{1}$ Utah State University, Department of Watershed Sciences, now U.S. Geological Survey.

${ }^{2}$ U.S. Geological Survey.

${ }^{3}$ Northern Arizona University, School of Earth Sciences and Environmental Sustainability.
}

Analysis of DEMs and channel cross sections show a spatially variable pattern of erosion and deposition, both within and between reaches. As much as 5 meters of scour occurred in pools downstream from flow constrictions, especially in channel segments where gravel bars were absent. By contrast, some channel cross sections were stable during the 2011 floods, and have shown almost no change in over a decade of monitoring. Partial mobility of gravel bars occurred, and although in some locations vegetation such as tamarisk (Tamarix ramosissima) was damaged, wholesale bed motion necessary to fully clear these surfaces was not evident. In flow recirculation zones, eddy sandbars aggraded one meter or more, increasing the area of bars exposed during typical dam operations. Yet overall, the 2011 flood resulted in a decrease in reach-scale sand storage because bed degradation exceeded bar deposition. The 2011 response is consistent with that of a similar event in 1999, which was followed by sand-bar erosion and sediment accumulation on the bed during subsequent years of normal dam operational flows. Although the 1999 and 2011 floods were exceptional in the post-dam system, they did not exceed the pre-dam 2-year flood, isolating their effects to the modern active channel with minor erosion or reworking of pre-dam deposits stabilized through vegetation encroachment.

\section{Introduction}

Since initial closure of Flaming Gorge Dam, Utah, in November 1962, the streamflow hydrology and the amount of fine sediment supplied to the upper Green River in the 105 kilometers $(\mathrm{km})$ between the dam and the Yampa River have been substantially altered (Grams and Schmidt, 2002). Farther downstream, the flow regime and the sediment supply have been altered to a lesser degree (Grams and Schmidt, 
2002). In response to these changes, the channel of the Green River has adjusted its form, the distribution of its bed material and bars, and the characteristics of its banks; these changes have been described in the greatly altered segment upstream from the Yampa River (Graf, 1980; Andrews, 1986; Grams, 1997; Grams and Schmidt, 1999, 2002, 2005; Martin, 2000; Merritt and Cooper, 2000; Grant and others, 2003; Larsen, 2003; Larsen and others, 2003; Larson, 2004; Alexander, 2007; Cooper and Andersen, 2012) and the less altered segments downstream from the Yampa River (Graf, 1978; Andrews, 1986; Lyons and others, 1992; Allred and Schmidt, 1999; Elliot, 2002; Grant and others, 2003; Birken and Cooper, 2006; DeWine and Cooper, 2007; Manners and others, 2011). In this report, the Green River between its headwaters and the confluence with the Yampa River is referred to as the upper Green River. The segment between the Yampa River and the town of Green River, Utah, is referred to as the middle Green River, and the most downstream segment is referred to as the lower Green River.

Streams and rivers erode or deposit sediment as a function of the balance between the amount sediment supplied to the channel and the sediment transport capacity. This balance is established by the flow regime released from the dam and the sediment and flow characteristics of tributaries that enter the river's mainstem downstream from the dam (Williams and Wolman, 1984; Schmidt and Wilcock, 2008). Morphologic response to changes in flow hydrology or sediment supply can range from short-term, event-based changes in bed elevation (scour and fill), to longer-term, annual to decadal scale changes in the reach-scale sediment volume (aggradation and degradation). Given the dynamic nature of river systems, event-based scour and fill may not be indicative of the longterm sediment mass balance. Rather, over longer timescales, persistent erosion may result in reach-scale incision, as along the Colorado River in Glen Canyon, Arizona (Grams and others, 2007), or simply sediment evacuation, as in the Colorado River in Grand Canyon, Arizona (Schmidt and others, 2004). In both cases, the sediment mass balance is negative, but in the latter case, erosion of sandbars has not been accompanied by incision, as immobile boulders at rapids constrain the longitudinal profile. Sediment accumulation and aggradation occur where the reduction in sediment transport capacity is greater than the reduction in sediment supply resulting in a sediment surplus, as has been observed along the Rio Grande River in Big Bend National Park, Texas (Dean and Schmidt, 2011).

The downstream geomorphic response of the Green River, and associated changes of the aquatic and riparian habitats, is primarily driven by the disequilibrium induced by the existence and operations of Flaming Gorge Dam. Flaming Gorge Reservoir completely traps the fine sediment once delivered to the upper Green River from tributaries draining much of southwestern Wyoming and the north slope of the Uinta Mountains (fig. 1). Operations of Flaming Gorge Dam reduce the magnitude and duration of the annual flood, change the timing of that flood, introduce daily fluctuations associated with the production of hydroelectricity, and increase the minimum flows to 23 cubic meters per second $\left(\mathrm{m}^{3} / \mathrm{s}\right)\left(800\right.$ cubic feet per second, $\left.\mathrm{ft}^{3} / \mathrm{s}\right)$. These changes have perturbed the fine sediment mass balance of the channel immediately downstream from the dam into sediment deficit (Schmidt and Wilcock, 2008), but it has not been established how far downstream the mass-balance deficit exists (Grams and Schmidt, 2005). Despite the perturbation into massbalance deficit, the alluvial channel in Browns Park, Colorado and Utah, immediately upstream of Dinosaur National Monument, has narrowed by approximately 25 percent (Grams and Schmidt, 2005), and the channel in the Canyon of Lodore (hereafter referred to as Lodore Canyon) has narrowed by approximately 20 percent (Grams and Schmidt, 2002). Schmidt and Wilcock (2008) demonstrated that channel narrowing occurs wherever the magnitude of annual floods is reduced, regardless of whether the sediment mass balance has been perturbed into deficit or surplus. This is the case throughout the middle and lower Green River where the channel has narrowed in response to reduction of the annual flood peak despite small perturbations in the fine sediment mass balance (Andrews, 1986; Allred and Schmidt, 1999; Birken and Cooper, 2006). The role of non-native tamarisk (Tamarix ramosissima) in accelerating channel narrowing by stabilizing banks and inducing floodplain aggradation is potentially significant (Graf, 1978; Birken and Cooper, 2006).

Operations of dams throughout the upper Colorado River basin have been modified to include controlled floods. Some of these floods have resulted from unusually wet periods when reservoirs filled and spillways and river outlet works were used to bypass large volumes of water. Such was the case throughout the watershed in the mid-1980s but was also the case in the upper Green River watershed in 1997, 1999, and 2011. All of these large releases used the river outlet works of Flaming Gorge Dam, and the spillway was used in 1983, 1997 (due to damage of a bypass tube), and 1999. Other types of controlled floods have been released from Flaming Gorge Dam for purposes of downstream environmental benefit. These releases are matched with the time when the natural flood of the Yampa River reaches its peak and are intended to increase the duration of peak flows in the middle Green River, thereby benefit spawning and rearing of some native fish species (Muth and others, 2000). Similarly, Pitlick (2006) demonstrates that coordinated high flow releases on the upper Colorado River could mobilize gravel bars with the hopes of removing encroaching vegetation and enhancing some aquatic habitats.

The pattern of high-flow releases from Flaming Gorge Dam in response to wet watershed conditions or for environmental purposes is similar to the pattern of large releases that have occurred at Glen Canyon Dam on the Colorado River (Schmidt and Grams, 2011). Although the floods released from Glen Canyon Dam have been carefully monitored for sediment transport, fine sediment mass balance, and the geomorphic response of near-shore alluvial deposits, substantially less attention has been given to monitoring similar processes in Lodore Canyon, nor of the middle Green River further 


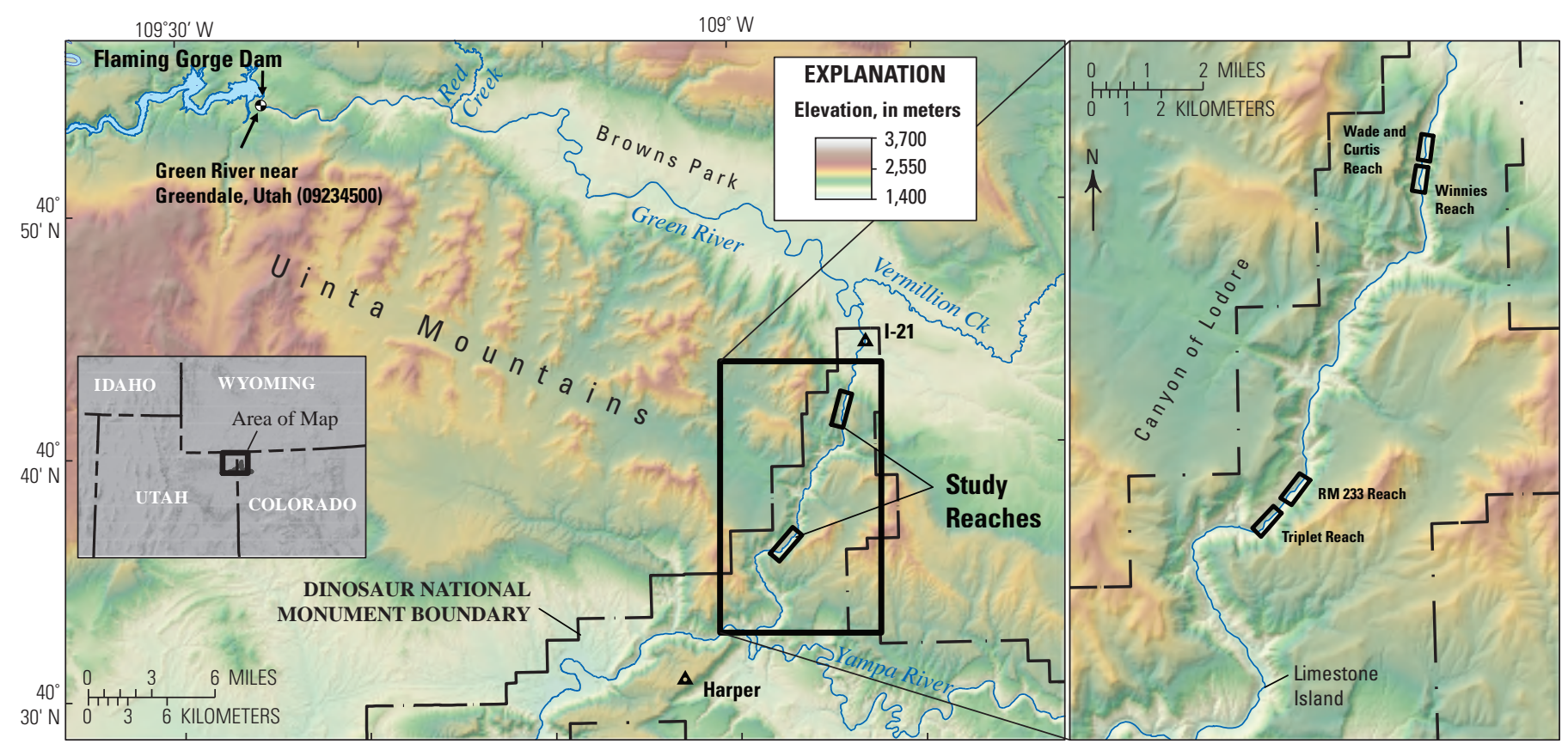

Basemap from National Elevation Dataset, 1/3 arc second (10 meter) resolution.

Figure 1. Location of the Canyon of Lodore within Dinosaur National Monument, Colorado and Utah, with the sites of newly occupied control stations shown as triangles (left); area shown in the rectangle indicates locations of study reaches on the Green River within the Canyon of Lodore (right).

downstream. Sediment transport was only measured at Gates of Lodore in 1997 and 1999 (Martin and others, 1998; Elliot and Anders, 2005), and geomorphic response of the channel was measured by graduate students and lab staff supervised by J.C. Schmidt at Utah State University. These measurements have only been described in administrative reports (Martin and others, 1998; Larsen and Schmidt, 2003).

Resource managers of Dinosaur National Monument are interested in the effects of high flows on riparian communities and on aquatic habitat and channel form. Thus, a rigorous and comprehensive summary and analyses of these data will help inform management of Flaming Gorge Dam and of the river corridor in Dinosaur National Monument. This also provides an opportunity for comparison with similar processes and impacts elsewhere in the Colorado River network, especially downstream from Glen Canyon Dam. The purpose of this report is to summarize the geomorphic response of the Green River in Lodore Canyon to a large dam release that occurred in 2011, and establish a consistent long-term protocol for future monitoring efforts. The instantaneous peak flow of $260 \mathrm{~m}^{3} / \mathrm{s}\left(9,190 \mathrm{ft}^{3} / \mathrm{s}\right)$ was the third highest and sustained flows of approximately $250 \mathrm{~m}^{3} / \mathrm{s}\left(8,800-8,900 \mathrm{ft}^{3} / \mathrm{s}\right)$ (fig. 2) were among the longest duration flood flows released from Flaming Gorge Dam since its completion (fig. 3).

\section{The Green River in the Canyon of Lodore}

The Green River in Lodore Canyon has incised through the eastern dome of the Uinta uplift, an east-trending Laramide-aged anticline consisting of a Precambrian core flanked by Mesozoic and Paleozoic sedimentary rocks (Hansen and others, 1983; Hansen, 1986). Tertiary basin fill sediments and erosion surfaces are common in the eastern Uinta Mountains, suggesting relatively recent integration of the upper and lower Green River systems. Thus, Lodore Canyon has been incised recently, in a geological sense, and has cut a narrow gorge through the south dipping limb of the anticline of the Uintas. The resistant layered quartzitic rocks of the Uinta Mountain Group are prominent in the upstream part of the canyon, and younger Cambrian and Paleozoic sedimentary rocks are exposed further downstream (Hansen and others, 1983). The canyon walls are very steep; typical relief from canyon rim to the river ranges between 300 and 800 meters (m) over horizontal distances of less than a kilometer. There are small variations in canyon width and the locations of tributary junctions are primarily determined by structural controls (Grams and Schmidt, 1999). 


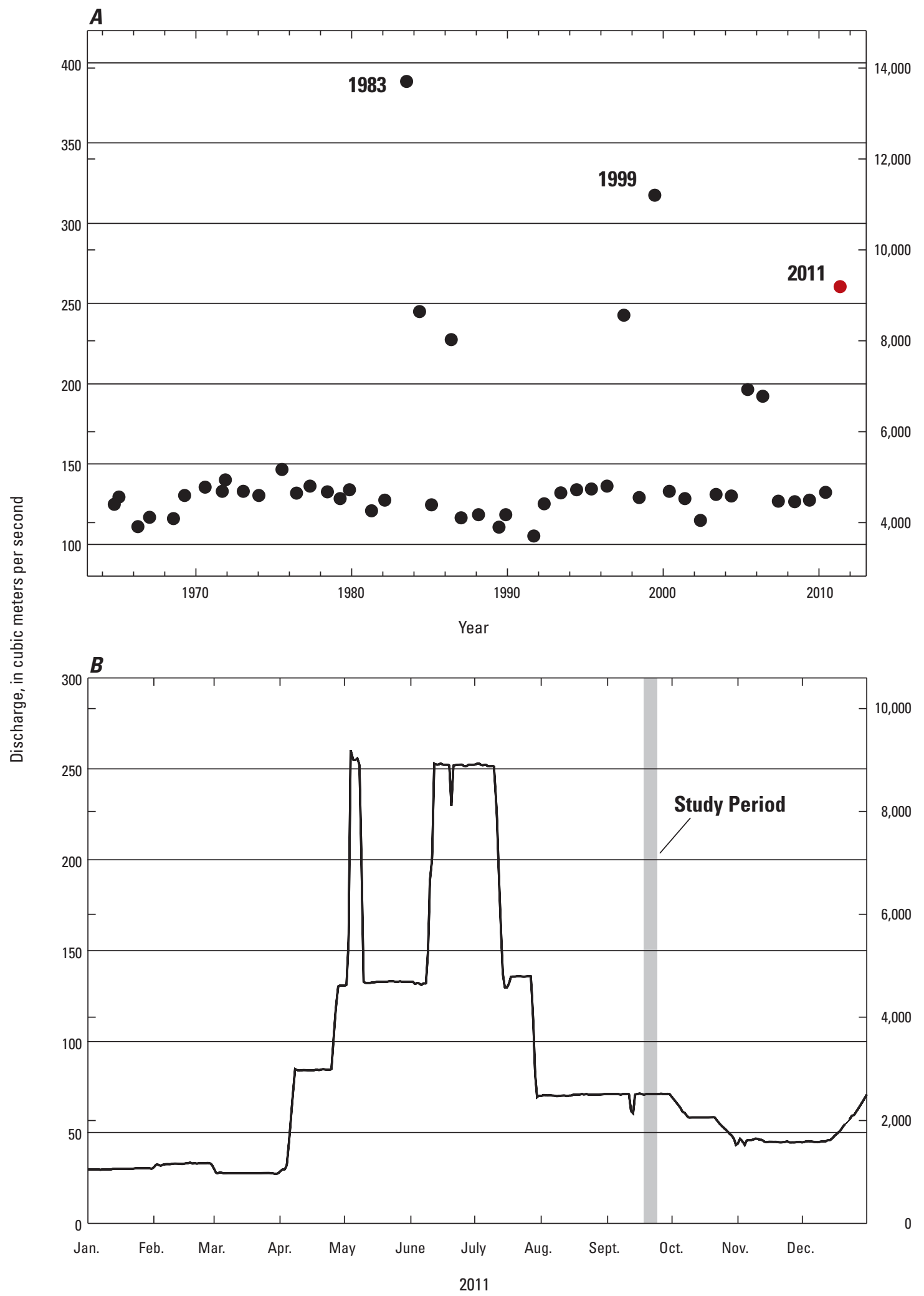

Figure 2. Discharge for the Green River near Greendale, Utah. $A$, Annual peak discharge since initial closure in November 1962 of Flaming Gorge Dam, Utah, measured at stream gage 09234500. B, Mean daily flow hydrograph for 2011. 


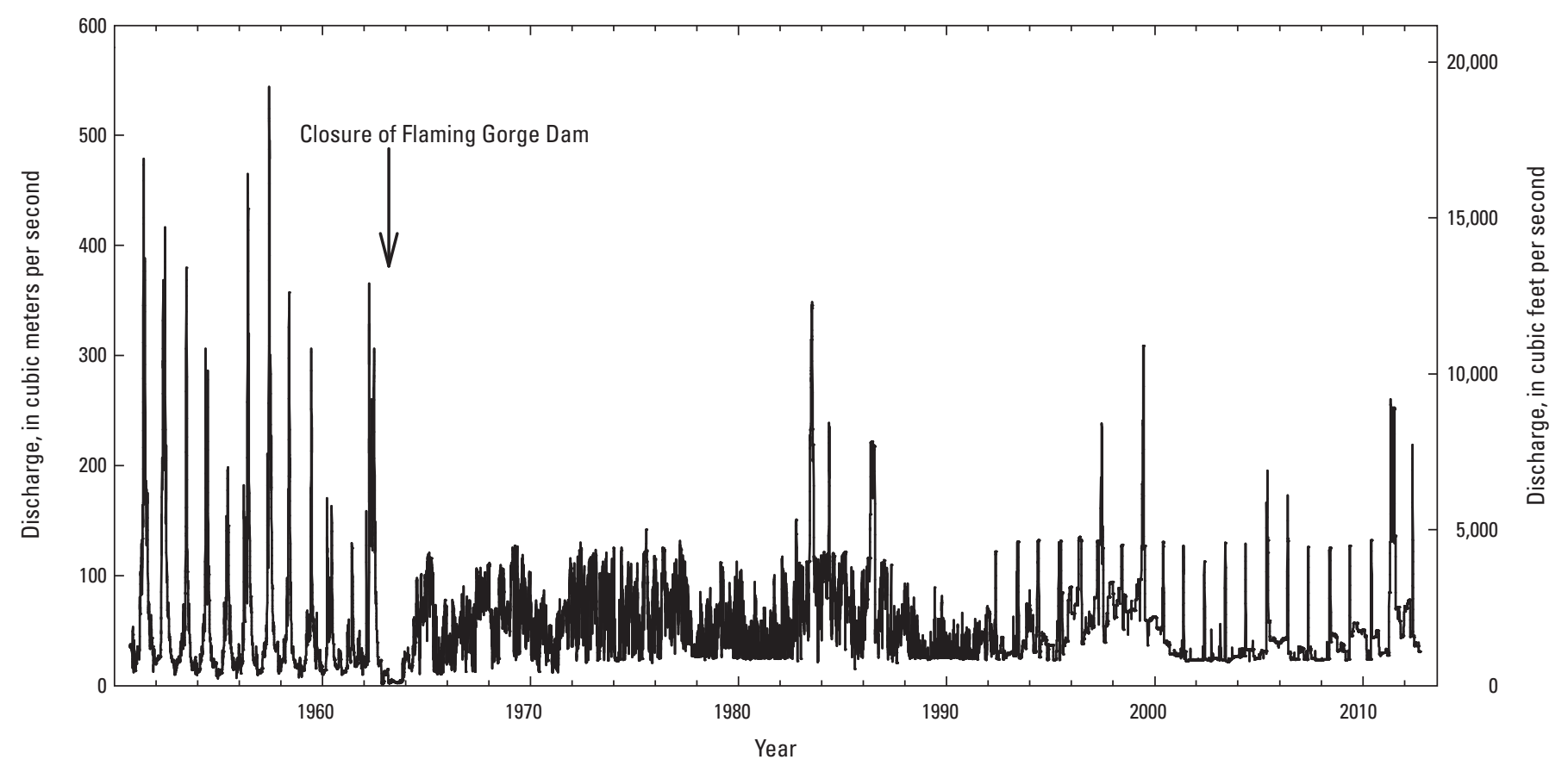

Figure 3. Mean daily discharge of the Green River near Greendale, Utah, from 1950 to 2012. Initial closure of Flaming Gorge Dam in November 1962 is indicated.

More than 60 tributary drainage basins capable of producing debris flows drain directly to the Green River in Lodore Canyon (Grams, 1997; Martin, 2000; Larsen, 2003). Debris fans at the mouths of these tributaries strongly influence the longitudinal profile and geomorphic organization of the Green River in a manner typical of debris-flow dominated river canyon corridors, such as the Colorado River in Grand Canyon and the Snake River in Hells Canyon (on the border of Idaho and Oregon and Washington) (Schmidt, 1990; Schmidt and others, 1995). In these settings, channel morphology and zones of fine sediment deposition are primarily determined by the hydraulic control caused by each debris fan; constricted flow and steep rapids occur opposite the debris fan, and lateral flow separation eddies occur immediately downstream (Howard and Dolan, 1981; Schmidt, 1990; Melis, 1997; Vincent and Andrews, 2008; Wright and Kaplinski, 2011). The geomorphic organization of the Colorado River in Grand Canyon has been described as pool-drop (Leopold, 1969; Magirl and others, 2008) and as fan-eddy complexes (Schmidt and Rubin, 1995). Lodore Canyon is similarly organized. A typical fan-eddy complex consists of an upstream ponded backwater, a downstream expansion pool with associated eddy deposits, and a gravel bar further downstream, composed of debris entrained from the fan (Schmidt and Rubin, 1995).

\section{Previous Work}

In the 1990s, Schmidt's lab group at Utah State University began what became a long-term program to understand the nature of channel adjustment to reduced flood flows, decreased sediment supply, and tamarisk encroachment along the upper Green River downstream from Flaming Gorge Dam, focusing primarily on Lodore Canyon. Grams (1997) and Grams and Schmidt $(1999,2002)$ showed that channels narrowed by approximately 20 to 25 percent throughout Browns Park and Lodore Canyon. In Lodore Canyon, channel narrowing largely occurred by vegetation stabilization and vertical accretion of fine sediment on gravel bars, and vegetation encroachment on eddy sandbars-especially those no longer inundated by post-dam flows (Grams and Schmidt, 2002). As a result, a stable intermediate bench formed on the pre-dam floodplain below a now inactive high-elevation terrace, but above the modern, post-dam floodplain (fig. 4) (Grams and Schmidt, 2002). In most reaches of Lodore Canyon, only the highest post-dam discharges inundate this intermediate surface, whereas typical annual flood peaks inundate the inset post-dam floodplain (appendix 1) (Grams and Schmidt, 2002). Alexander (2007) showed that most of the sediment on the intermediate bench was deposited by two discrete events, the pre-dam 1962 flood and the 1983 controlled flood released from the dam. In addition, there was widespread tamarisk recruitment on this surface in 1962 and 1963 (Cooper and others, 2003). The result is that today's Green River channel in Lodore Canyon is narrower, and vegetation encroachment has occurred on previously active bars and channel margins, thereby converting these surfaces to today's active floodplain. These surfaces are likely to continue to accrete during high flows, which may further isolate these surfaces from typical dam release flows.

Alexander (2007) compiled previous channel-change measurements. He showed that average peak flows, which are 


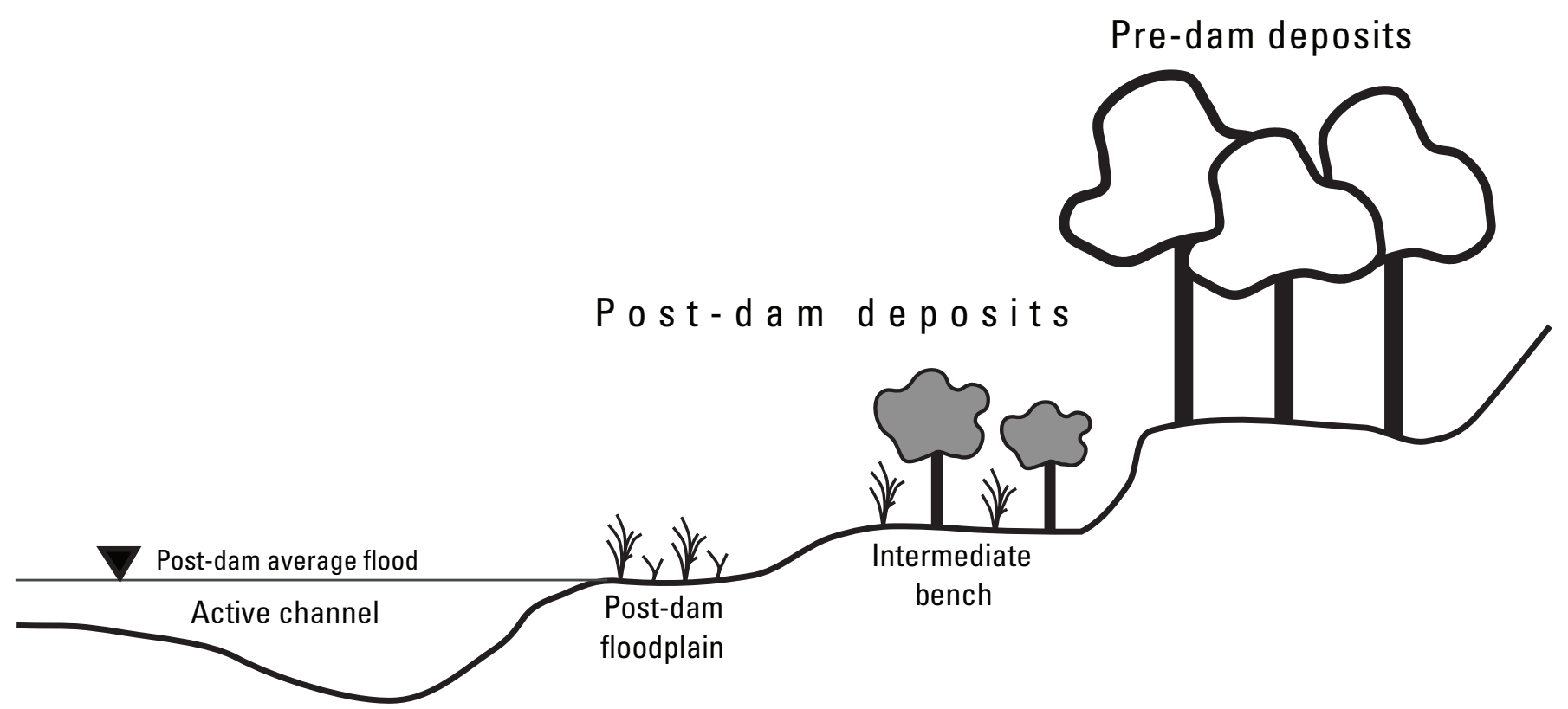

Figure 4. Geomorphic levels (terrace and floodplain surfaces) relative to the stage of a typical post-dam flood for the Green River downstream from Flaming Gorge Dam, Colorado and Utah (modified from Grams and Schmidt, 2005).

about $125 \mathrm{~m}^{3} / \mathrm{s}$ and occur when the power plant is operated at maximum capacity, have had minimal impact on sand storage at monitored cross sections. Sandbar aggradation occurred during the 1997 flood of $243 \mathrm{~m}^{3} / \mathrm{s}$ (Martin and others, 1998), and significant channel changes were caused by these high flows. The $317 \mathrm{~m}^{3} / \mathrm{s}$ flood of 1999 was characterized by scour of some pools, particularly in pools directly downstream from debris flows, and concomitant eddy sandbar aggradation (Larsen and Schmidt, 2003; Alexander, 2007). Subsequent years of low to moderate dam releases tended to drive the channel back towards conditions presumed to have existed before the flood; thus, sandbars were eroded and deeper pools filled. Alexander (2007) also showed that although floodplain aggradation during post-dam flows indicated enhanced sediment storage in Lodore Canyon, most of this deposition had occurred by the mid-1980s, and there is little evidence for changes in sediment storage in the study reaches since at least 1994. Although speculated by Andrews (1986), channel incision has never been noted in Lodore Canyon (Grams and Schmidt, 1999), because the channel gradient is determined by the boulders that form the bed at each rapid.

These findings contrast with the sediment deficit conditions of the Colorado River downstream from Glen Canyon Dam, where sandbar erosion has occurred and where the $25-\mathrm{km}$ segment immediately downstream from the dam has been incised (Grams and others, 2007). Fine sediment inputs to Lodore Canyon from Red Creek and Vermillion Creek, and from bank erosion in Browns Park (Martin and others, 1998; Merritt and Cooper, 2000; Grams and Schmidt, 2005) likely buffer the effects of sediment trapping by Flaming Gorge
Reservoir. Yet the sediment mass balance in Lodore Canyon is uncertain; the mass balance may be in equilibrium or in deficit (Grams and Schmidt, 2005). However, even if deficit exists in, it is likely less severe than the deficit downstream from Glen Canyon Dam. Lodore Canyon, therefore, provides a useful comparison for the evaluation of channel changes downstream from large dams, particularly with respect to the potential of controlled floods to alter the post-dam relation between sediment supply and transport capacity.

\section{Study Area}

This work focuses on four primary study reaches in Lodore Canyon that were established between 1999 and 2001 to monitor channel change associated with experimental tamarisk removal. Each reach is associated with a fan-eddy complex; these sites include two "tamarisk removal" and two "experimental control" reaches (Alexander, 2007). One additional site, Limestone Island, where gravel entrainment studies were conducted is also discussed (fig. 1). Tamarisk was removed from $\sim 1 \mathrm{~km}$ reaches near Winnies Rapid (hereafter referred to as the Winnies reach) and River Mile 233 (hereafter referred to as the RM233 reach). Control reaches, where no tamarisk was removed, were established near Wade and Curtis camp (referred to as the Wade and Curtis reach) and Triplet Rapids (referred to as the Triplet reach). Alexander (2007) described the floodplain stratigraphy and Larson (2004) mapped the surficial geology of these reaches. 
Eight cross sections have been resurveyed periodically in each reach, dating back to 1994 in some cases, and to 2001 at all locations (table 1) (Alexander, 2007). Before 2011, the most recent survey of these cross sections was in 2006. Maps of surficial geology and geomorphic surfaces of each reach allow measurement of the degree of post-dam channel narrowing, based on the extent of the intermediate bench and modern floodplain, neither of which are assumed to have existed before 1963 (appendix 1) (Grams, 1997; Grams and Schmidt, 2002). Four to six cross sections were spaced evenly in the pool upstream from the debris flow that acted as the primary hydraulic control in each reach, and each reach included active eddy sandbars and channel-margin deposits. Two to four additional cross sections were located in the downstream part of the reach and typically included a gravel bar and fine sediment deposited in flow recirculation zones (appendix 1).

Table 1. Dates and locations for cross-section surveys used in geomorphic change analysis on the Green River in the Canyon of Lodore, Dinosaur National Monument, Colorado and Utah.

[Surveys were completed within a week of the date indicated by x. Date format is Month/Day/Year. WC, Wand and Curtis; WIN, Winnies; RM, river mile; TRIP, Triplet]

\begin{tabular}{|c|c|c|c|c|c|c|c|c|c|c|c|c|c|c|c|c|c|c|c|c|c|c|c|c|}
\hline SITE & \multicolumn{24}{|c|}{ DATE } \\
\hline & 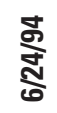 & $\begin{array}{l}\text { 芯 } \\
\stackrel{\infty}{\infty}\end{array}$ & 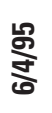 & 足 & $\stackrel{\mathscr{D}}{\stackrel{\circ}{\circ}}$ & $\frac{\mathscr{\sigma}}{\frac{\infty}{6}}$ & 趈 & $\frac{\delta}{\delta}$ & 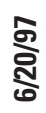 & 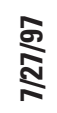 & 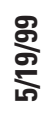 & $\frac{\frac{8}{6}}{\frac{6}{6}}$ & $\frac{\text { S }}{\stackrel{\text { S }}{6}}$ & $\frac{\operatorname{g}}{\infty}$ & $\underset{\Sigma}{\delta}$ & స్వু & $\underset{\infty}{\stackrel{\infty}{\infty}}$ & $\frac{\Upsilon_{\infty}^{\infty}}{\overbrace{\infty}}$ & 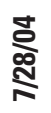 & 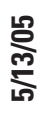 & 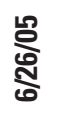 & $\stackrel{\text { 농 }}{\stackrel{2}{\Sigma}}$ & 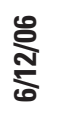 & 동 \\
\hline WC1 & & & & & & & & & & & & & & & $\mathrm{x}$ & & & $\mathrm{x}$ & $\mathrm{x}$ & & & & $\mathrm{x}$ & $\mathrm{x}$ \\
\hline WC2 & & & & & & & & & & & & & & & $\mathrm{x}$ & & $\mathrm{x}$ & $\mathrm{x}$ & & & & & $\mathrm{x}$ & $\mathrm{x}$ \\
\hline WC3 & & & & & & & & & & & & & & & $x$ & & $\mathrm{x}$ & $\mathrm{x}$ & & $\mathrm{x}$ & & $\mathrm{x}$ & $\mathrm{x}$ & $\mathrm{x}$ \\
\hline WC4 & & & & & & & & & & & & & & & $\mathrm{x}$ & & $\mathrm{x}$ & $\mathrm{x}$ & & $\mathrm{x}$ & & $\mathrm{x}$ & $\mathrm{x}$ & $\mathrm{x}$ \\
\hline WC5 & & & & & & & & & & & & & & & $\mathrm{x}$ & & & $\mathrm{x}$ & & & & & $\mathrm{x}$ & $\mathrm{x}$ \\
\hline WC6 & $\mathrm{x}$ & & & & & & & & & & & & & & $\mathrm{x}$ & & & $\mathrm{x}$ & & & & & $\mathrm{x}$ & $\mathrm{x}$ \\
\hline WC7 & & & & & & & & & & & & & & & $\mathrm{x}$ & & & $\mathrm{x}$ & $\mathrm{x}$ & $\mathrm{x}$ & & $\mathrm{x}$ & $\mathrm{x}$ & $\mathrm{x}$ \\
\hline WC8 & & & & & & & & & & & & & & & $\mathrm{x}$ & & & $\mathrm{x}$ & $\mathrm{x}$ & $\mathrm{x}$ & & $\mathrm{x}$ & $\mathrm{x}$ & $\mathrm{x}$ \\
\hline WIN1 & & & & & & & & & & & $\mathrm{x}$ & $\mathrm{x}$ & $\mathrm{x}$ & $\mathrm{x}$ & $\mathrm{x}$ & & & $\mathrm{x}$ & $\mathrm{x}$ & & & & $\mathrm{x}$ & $\mathrm{x}$ \\
\hline WIN2 & & & & & & & & & & & $\mathrm{x}$ & $\mathrm{x}$ & $\mathrm{x}$ & $\mathrm{x}$ & $\mathrm{x}$ & & & $\mathrm{x}$ & & $\mathrm{x}$ & & $\mathrm{x}$ & $\mathrm{x}$ & $\mathrm{x}$ \\
\hline WIN3 & & & & & & & & & & & $\mathrm{x}$ & $\mathrm{x}$ & $\mathrm{x}$ & $\mathrm{x}$ & $\mathrm{x}$ & & $\mathrm{x}$ & $\mathrm{x}$ & & $\mathrm{x}$ & & $\mathrm{x}$ & $\mathrm{x}$ & $\mathrm{x}$ \\
\hline WIN4 & & & & & & & & & & & $\mathrm{x}$ & $\mathrm{x}$ & $\mathrm{x}$ & $\mathrm{x}$ & $\mathrm{x}$ & & $\mathrm{x}$ & $\mathrm{x}$ & & & & & $\mathrm{x}$ & $\mathrm{x}$ \\
\hline WIN5 & & & & & & & & & & & $\mathrm{x}$ & $\mathrm{x}$ & $\mathrm{x}$ & $\mathrm{x}$ & $\mathrm{x}$ & & & $\mathrm{x}$ & & & & & $\mathrm{x}$ & $\mathrm{x}$ \\
\hline WIN6 & & & & & & & & & & & $\mathrm{x}$ & $\mathrm{x}$ & & $\mathrm{x}$ & $\mathrm{x}$ & & & $\mathrm{x}$ & & & & & $\mathrm{x}$ & $\mathrm{x}$ \\
\hline WIN7 & & & & & & & & & & & $\mathrm{x}$ & $\mathrm{x}$ & $\mathrm{x}$ & $\mathrm{x}$ & $\mathrm{x}$ & & & $\mathrm{x}$ & & $\mathrm{x}$ & $\mathrm{x}$ & & $\mathrm{x}$ & $\mathrm{x}$ \\
\hline WIN8 & & & & & & & & & & & $\mathrm{x}$ & $\mathrm{x}$ & $\mathrm{x}$ & $\mathrm{x}$ & $\mathrm{x}$ & & $\mathrm{x}$ & $\mathrm{x}$ & $\mathrm{x}$ & $\mathrm{x}$ & $\mathrm{x}$ & & $\mathrm{x}$ & $\mathrm{x}$ \\
\hline RM233-1 & $\mathrm{x}$ & & $\mathrm{x}$ & $\mathrm{x}$ & $\mathrm{x}$ & $\mathrm{x}$ & & $\mathrm{x}$ & $\mathrm{x}$ & $\mathrm{x}$ & $\mathrm{x}$ & $\mathrm{x}$ & $\mathrm{x}$ & $\mathrm{x}$ & $\mathrm{x}$ & & & $\mathrm{x}$ & $\mathrm{x}$ & $\mathrm{x}$ & & $\mathrm{x}$ & $\mathrm{x}$ & $\mathrm{x}$ \\
\hline RM233-2 & & & & & & & & & & & $\mathrm{x}$ & $\mathrm{x}$ & $\mathrm{x}$ & $\mathrm{x}$ & $\mathrm{x}$ & & & $\mathrm{x}$ & $\mathrm{x}$ & $\mathrm{x}$ & & $\mathrm{x}$ & $\mathrm{x}$ & $\mathrm{x}$ \\
\hline RM233-3 & & & & & & & & & & & $\mathrm{x}$ & $\mathrm{x}$ & $\mathrm{x}$ & $\mathrm{x}$ & $\mathrm{x}$ & & & $\mathrm{x}$ & & & & & $\mathrm{x}$ & $\mathrm{x}$ \\
\hline RM233-4 & & $\mathrm{x}$ & & & $\mathrm{x}$ & $\mathrm{x}$ & $\mathrm{x}$ & $\mathrm{x}$ & $\mathrm{x}$ & $\mathrm{x}$ & $\mathrm{x}$ & $\mathrm{x}$ & $\mathrm{x}$ & $\mathrm{x}$ & $\mathrm{x}$ & & & $\mathrm{x}$ & & & & & $\mathrm{x}$ & $\mathrm{x}$ \\
\hline RM233-5 & & & & & & & & & & & $\mathrm{x}$ & & & & $\mathrm{x}$ & & & $\mathrm{x}$ & & & & & $\mathrm{x}$ & $\mathrm{x}$ \\
\hline RM233-6 & & $\mathrm{x}$ & & & & & & & & & $\mathrm{x}$ & & & & $\mathrm{x}$ & & & $\mathrm{x}$ & & & $\mathrm{x}$ & & $\mathrm{x}$ & $\mathrm{x}$ \\
\hline RM233-7 & & & & & & & & & & & $\mathrm{x}$ & & & $\mathrm{x}$ & $\mathrm{x}$ & & & $\mathrm{x}$ & & $\mathrm{x}$ & $\mathrm{x}$ & & $\mathrm{x}$ & $\mathrm{x}$ \\
\hline RM233-8 & & $\mathrm{x}$ & & & & & & & & & & & $\mathrm{x}$ & $\mathrm{x}$ & $\mathrm{x}$ & & & $\mathrm{x}$ & & $\mathrm{x}$ & $\mathrm{x}$ & & $\mathrm{x}$ & $\mathrm{x}$ \\
\hline TRIP1 & & & & & & & & & & & & & & & & $\mathrm{x}$ & & $\mathrm{x}$ & $\mathrm{x}$ & & & & $\mathrm{x}$ & $\mathrm{x}$ \\
\hline TRIP2 & & & & & & & & & & & & & & & & $\mathrm{x}$ & & $\mathrm{x}$ & $\mathrm{x}$ & $\mathrm{x}$ & & $\mathrm{x}$ & $\mathrm{x}$ & $\mathrm{x}$ \\
\hline TRIP3 & & & & & & & & & & & & & & & & $\mathrm{x}$ & & $\mathrm{x}$ & & $\mathrm{x}$ & & $\mathrm{x}$ & $\mathrm{x}$ & $\mathrm{x}$ \\
\hline TRIP4 & & & & & & & & & & & & & & & & $\mathrm{x}$ & & $\mathrm{x}$ & & & & & $\mathrm{x}$ & $\mathrm{x}$ \\
\hline TRIP5 & & & & & & & & & & & & & & & & $\mathrm{x}$ & & $\mathrm{x}$ & & $\mathrm{x}$ & & $\mathrm{x}$ & $\mathrm{x}$ & $\mathrm{x}$ \\
\hline TRIP6 & & & & & & & & & & & & & & & & $\mathrm{x}$ & & $\mathrm{x}$ & & $\mathrm{x}$ & & $\mathrm{x}$ & $\mathrm{x}$ & $\mathrm{x}$ \\
\hline
\end{tabular}




\section{Purpose and Scope}

This report describes field data collected in September 2011. As part of this effort, the U.S. Geological Survey (USGS) and Northern Arizona University established canyon-rim geodetic control points and survey monuments in the river corridor, thereby establishing a control network to tie past and future monitoring data to high-accuracy spatial and elevation control. We also describe the sedimentology and vertical structure of newly deposited sandbars and assess coarse sediment mobility through painted tracer rock recovery at five gravel bars. The primary purposes of this report are to:

1. Describe the robust rim-to-river survey control network, so that it is available for use in future monitoring efforts and can be integrated with previous surveys;

2. Document techniques used in river corridor surveying in the monitoring reaches, including description of digital elevation model development and resurveys of monumented cross sections;

3. Describe observed spatial variations in channel change and sandbar building and gravel/cobble mobility so as to inform understanding of sediment transport dynamics during the 2011 high flow event; and

4. Provide a summary of the effects of the 2011 high flows in the context of measurements made in this study and in previous studies of channel change at these sites.

\section{Methods}

The sections below describe the methods used to survey and process the field data collected following the 2011 flood. First, we present survey techniques and the associated methods to construct two- and three-dimensional topographic surfaces. We then present the techniques for detecting geomorphic change from previous surveys. Last, we describe the methods used to document sandbar and gravel-bar change based on direct measurements of sedimentology and tracerrock movement.

\section{Geodetic Control}

The control network within Lodore Canyon is referenced to NAD83(NSRS2007) through simultaneous observations with five control stations, observed under open sky with few obstructions. Two of the control stations are Continuously Operating Reference Stations (CORS sites MYT2, CNC1) located in Utah and Colorado southwest and south from the study area, respectively, and one station located in Browns Park that was a Height Modernization station (HOPE). Data for these stations are published by the National Geodetic Survey (NGS) (http://www.ngs.noaa.gov/cgi-bin/datasheet. prl). Two additional "rim" stations (Harper and I-21) were occupied with Global Navigation Satellite System (GNSS: GPS/GLONASS) receivers for the first time (fig. 1, fig. 5A). Because Harper and I-21 did not have enough observations for inclusion in the official NGS database (referred to as "bluebooking"), these data are published under a different and less strenuous method called the Online Positioning User Service Database (OPUS-DB) (http://www.ngs.noaa.gov/OPUS/view. jsp). For the river control (for example, fig. 5B), GNSS data processing and least-squares adjustment was done with Trimble Business Center version 2.60 software, using final precise ephemeris orbits, ionospheric modeling, and NGS absolute antenna models. The quality of the data was compromised by time constraints, and multiple observations were made on less than half of the river corridor GNSS points. The adjustment was constrained to NAD83 (NSRS2007). Conventional optical measurements (using total stations) were constrained to the GNSS network results to provide additional density of river corridor control. The control network coordinates were projected to the NAD83 Colorado State Plane (NSRS 2007) north zone 0501 grid (Northings, Eastings, NAD83 Ellipsoid Heights) in meters. Ground distances (control network, topography, and bathymetry) were reduced to the state plane grid by a combined scale factor of $\sim 0.999730$, or $\sim 0.27 \mathrm{~m}$ per $\mathrm{km}$. The coordinates of these control points are given in the results section.

\section{Bathymetric Surveying}

We collected bathymetric data using single-beam sonar deployed from a motorized raft equipped with a front-mounted mast, with the sonar echo sounder located at the base and a laser target on top for tracking (fig. 5C). A computer for monitoring the incoming data stream and tracking position in the channel was housed in an aluminum box, which was sealed during downstream river travel. The echo sounder was an Odom CV-100 with a 200 kilohertz (kHz) transducer. GNSS receivers are unreliable for kinematic positioning in narrow canyons due to variations in the geometric integrity (PDOP) and multipath errors created by canyon walls. As a result, we used a line-of-sight range-azimuth navigation system for these surveys. The range-azimuth system used a robotic total station located on a river corridor control-point benchmark to track the position and elevation of a target mounted on the survey vessel. The raw positioning information (slope distance and horizontal and vertical angles) was referenced to the benchmark and transmitted back to the vessel by radio modems 12 to 15 times per second. The measured depths were then subtracted from the elevation of the transducer to derive bed elevations. We used a Trimble SPS930 instrument to track the survey vessel. The accuracy of the Trimble SPS930 to a target moving at 1 meter per second $(\mathrm{m} / \mathrm{s})$ is specified by the manufacturer as \pm 2 millimeters (mm) for horizontal, vertical, and slope distance measurements. 
Bathymetric survey techniques were those developed and tested in the Colorado River downstream from Glen Canyon Dam (Kaplinski and others, 2009). Survey lines were spaced roughly $5-15 \mathrm{~m}$ in the stream-wise direction and $5 \mathrm{~m}$ in the cross-stream direction to depths as shallow as $0.5 \mathrm{~m}$ near the banks where ground surveys could fill the gaps. Extra care was taken to document the bathymetry at monumented cross sections and in some cases included multiple passes.

\section{Conventional Surveying}

Conventional surveys in the river corridor were used to measure onshore and near shore topography to supplement the bathymetric data and create a digital terrain model of each reach. Several surveyors operated total stations (fig. 5D) simultaneously to maximize data collection using multiple rodmen and backsight stations. All instrument locations and backsights were located at monumented benchmarks that were later tied into the geodetic control network. We selected backsight locations to be visible from multiple instrument setup locations. Each backsight location consisted of a reflective prism mounted on a level tribrach situated on a tripod. The techniques here are similar to those used in Grand Canyon, where steep canyon walls also preclude the use of real-time kinematic Global Positioning System (GPS) (Hazel and others, 2008). Hazel and others (2008) assessed the horizontal and vertical accuracy of conventional surveys and reported a range from $\pm 0.05-0.25 \mathrm{~m}$ (horizontal) and $\pm 0.05-0.09 \mathrm{~m}$ (vertical), although closer to the lower end at the standard rod height typically used.

Ground-based surveys included detailed onshore and near-shore topographic measurements at 8 monumented cross sections in each reach; vegetation plots were also surveyed (table 2). In addition, bank and bar surveys along the entire length of each reach were completed where practicable, with focus on describing the topography of active bars and the active floodplain, water-surface elevations, and the estimated 2011 high-water line. The ground-based surveys included shallow-water offshore locations to tie in with the bathymetric survey data. We also documented sharp topographic breaks in slope, such as bank tops, and continuous features, such as river's edge, and converted these surveys into vector features (lines, polygons) to use as breaklines.

\section{Digital Terrain Models}

Previous cross-section surveys in Lodore Canyon have documented topographic change using ground-based surveys for onshore and nearshore locations and bathymetric surveys with a fathometer for deeper parts of each transect. However, because of their limited spatial extent, simple cross-sectional surveys do not always reveal form and process relations at the reach scale. Thus, interpretations of channel change interpreted from cross-section survey data can lead to potentially conflicting interpretations of long-term changes in channel sediment storage (Hazel and other, 2008). These conflicting interpretations were one impetus for the reach-scale surveys described here. The survey data documented in this report are of sufficient detail to detect geomorphic change on the scale of tens of centimeters or less (see below) and along long reaches, allowing linkage of eddy sandbar erosion or deposition to morphologic change in adjacent channels (for example, Hazel and others, 2010; Wright and Kaplinski, 2011). We also compared our 2011 survey data with similar survey data collected in 2001, thereby providing an initial test of the utility of these reach-scale surveys for detecting topographic change. Data collected in 2001 were converted to DEMs as described below for the 2011 data.

To convert discrete points into three-dimensional topographic surfaces, we interpolated the data using triangular irregular networks (TINs). TINs are vector representations of surfaces created by fitting a series of overlapping triangles to surveyed data points (x,y, and $\mathrm{z}$ ) using Delauny Triangulation (McCullagh, 1988). Accurate surface representation using TIN models requires high-density data in areas of abrupt topographic change, and fewer points can be used to characterize smooth surfaces. Additionally, TINs can take into account continuous breaks in slope measured in the field (breaklines), thereby preserving the sharp boundaries commonly associated with stream banks or terraces. In this study, the ground surveys and bathymetric data were combined to create the reach-scale TINs. The bathymetric data were filtered using the Hypack ${ }^{\circledR}$ software to give one sounding for every meter of horizontal distance (Kaplinski and others, 2009); although higher resolution data were available, the 1-m data were found to provide sufficient detail without resulting in TIN anomalies due to a very high number of vertices along the bathymetric trace. From the TINs, we created $0.25-\mathrm{m}$ contour maps to locate topographic errors or misrepresentations, and, in some cases, data points were eliminated to correct these issues.

The TIN surfaces were interpolated to a 1-m resolution grid (raster) using the TIN-to-Raster tool in ArcGIS ${ }^{\circledR}$ which preserves the breakline information from the original TIN surface. We interpolated the TIN surface to a 1-m raster using the natural neighbor technique in $\operatorname{ArcGIS} \AA$. This technique weights the values of known points according to how close they are to the interpolation point using Thiessen polygons (Sibson, 1981). The resulting DEMs are presented with the results and used for raster-based differencing to detect geomorphic change between the 2001 and 2011 surveys.

\section{Uncertainty in TIN and DEM surfaces}

The accuracy of elevations for the three-dimensional topographic surfaces is a function of both measurement and interpolation uncertainty. Measurement uncertainty for the bathymetric data was assessed using a cross-line check that compares the elevation of soundings from different boat transects where the different soundings intersect. Evaluation of 238 point pairs within $0.05-0.10 \mathrm{~m}$ of each other show a mean absolute error (MAE) of $0.017 \mathrm{~m}$ and a root-mean-square 


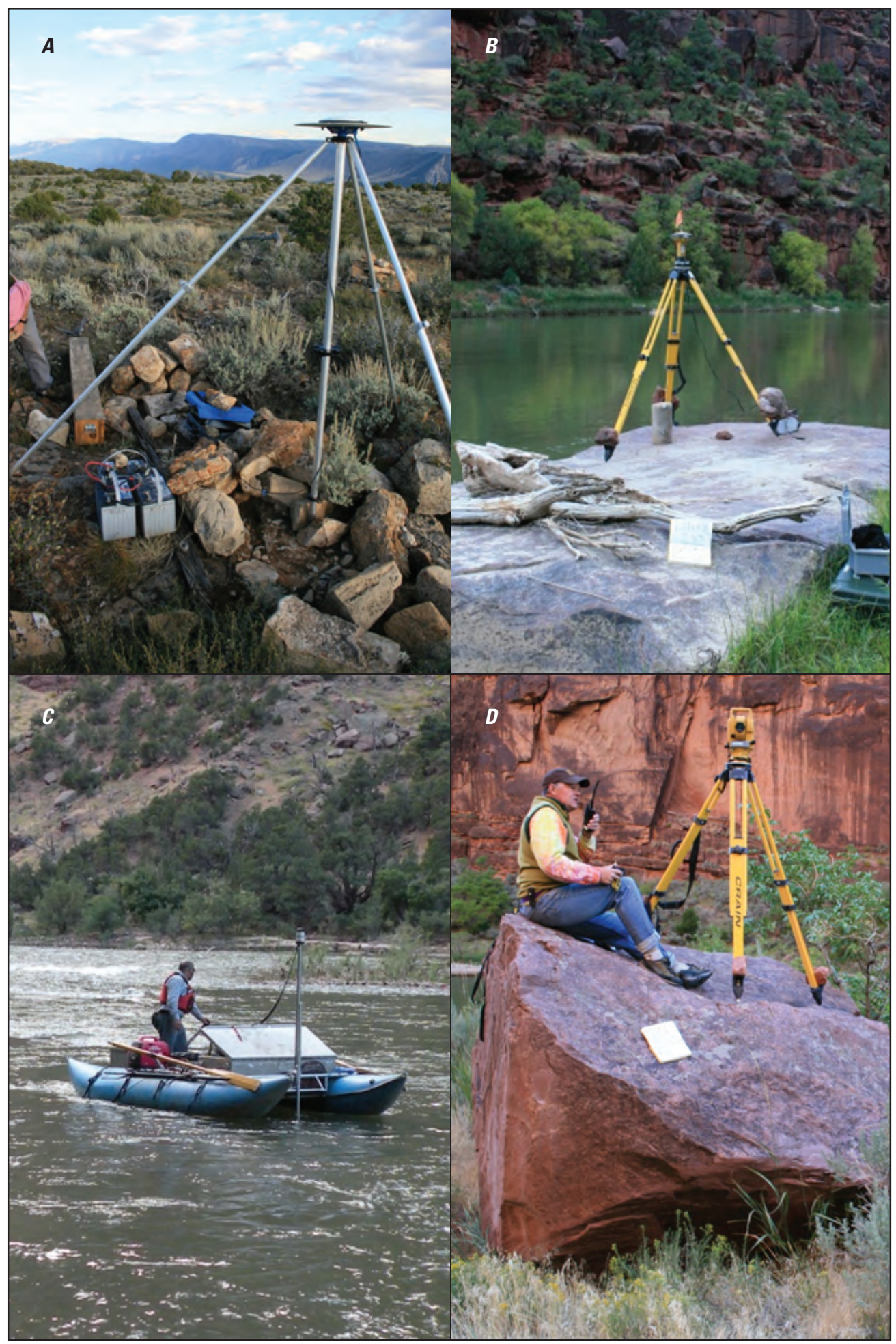

Figure 5. Field photographs from the Canyon of Lodore, Dinosaur National Monument, Colorado and Utah, showing $(A)$ Global Navigation Satellite System (GNSS) receiver set up at a canyon-rim station (Harper); (B) GNSS receiver positioned at a river corridor control point (RM233, GR233.19L); $(C)$ bathymetric surveying where front mast on raft is equipped with a positioning laser target on top (for tracking using a geodimeter) and a submerged transducer on the bottom for single-beam sonar; and $(D)$ total station set up for conventional surveys in river corridor (Winnies reach, GR248.48R). 
error (RMSE) of $0.023 \mathrm{~m}$. Vertical errors in the ground-based data were assumed to be $0.05 \mathrm{~m}$ for typical survey rod heights (Hazel and others, 2008).

We assessed interpolation uncertainty in the TIN and DEM surfaces by censoring a subset of 10 percent of the points from the dataset and using the remaining 90 percent of the points to interpolate the topographic surface. We then used the 10-percent subset to assess the accuracy of the interpolated surface elevations. Following Bennion (2009), the best 95 percent (roughly \pm 2 standard deviations) of the error (subset) dataset were used to assess the accuracy of the survey. In this analysis, we treated the bathymetric and ground survey data separately; in both cases, the TIN and DEM results were nearly indistinguishable, and only one value is reported here. For the bathymetric data, the MAE was $0.044 \mathrm{~m}$, and the RMSE was $0.06 \mathrm{~m}$; for the ground survey data, the MAE was $0.072 \mathrm{~m}$, and the RMSE was 0.11. Following the Federal Geodetic Data Committee (FGDC) standard, the uncertainty at 95-percent confidence for these surfaces can be found as $1.96 \times$ RMSE for the measurement and interpolation errors. Using this method, the measurement uncertainty at 95-percent confidence is $\pm 0.045 \mathrm{~m}$ and $\pm 0.10 \mathrm{~m}$ for the bathymetric and ground-based data, respectively. Interpolation uncertainty at 95-percent confidence for the DEMs ranges is $\pm 0.12 \mathrm{~m}$ for bathymetry and $\pm 0.22 \mathrm{~m}$ for ground surveys, respectively. Part of the reason for the greater value in the ground survey data is a tendency for many of the points in the 10-percent subset to fall near the DEM boundary because of the narrow surveyed region between the channel and canyon walls. The 10-percent subset method is also less appropriate on ground-survey data, because points are selected based on topographic necessity; thus, this error should be considered very conservative. On large bar surfaces of greater interest, the error is typically much less. In any case, these uncertainties are within the range reported in previous studies (Hazel and others, 2008; Kaplinski and others, 2009; Bennion, 2009) and sufficiently low to detect local geomorphic change at the centimeter to decimeter scale. Further, current research along the Colorado River in Marble Canyon shows that errors in DEM surfaces are typically randomly distributed, and reach-scale changes in volume often have much less uncertainty than individual, local point measurements (Grams and others, 2013).

\section{DEM Differencing}

We created DEMs of topographic difference (DoDs) for each reach by subtracting the 2001 DEM of nearshore and subaerial total station surveys of channel banks and bars from the 2011 DEM, wherever these surfaces overlapped. Raster creation for the 2001 data followed the methods presented above for the 2011 data. The DEMs were concurrent, with exact overlap of the cells in each DEM surface. We used the raster calculator in $\operatorname{ArcGIS} \circledast$ to determine the difference in elevation between these DEMs. We chose a minimum level of detection threshold of $\pm 0.25 \mathrm{~m}$, a conservative value given the uncertainties discussed in the previous section. Although more detailed spatial representations of uncertainty have been developed (Wheaton and others, 2010; Erwin and others, 2012), these are particularly important for assessing the accuracy of morphologic sediment budgeting. Because our difference maps only cover bars and channel margins, we cannot develop a meaningful sediment budget for the study reaches using this method. Instead, we present these data as complementary to our cross-section change analysis to highlight the location and magnitude of significant (greater than $\pm 0.25 \mathrm{~m}$ ) bar and bank erosion or deposition in response to the 2011 high flow. Future studies using these DEM surfaces for volumetric sediment budgeting should incorporate more sophisticated uncertainty or error analysis (see Wheaton and others, 2010).

Table 2. Data collection at each reach on the Green River during the 2011 field campaign in the Canyon of Lodore, Dinosaur National Monument, Colorado and Utah.

$[\mathrm{RM}$, river mile; --, no data]

\begin{tabular}{|c|c|c|c|c|c|c|}
\hline \multirow[b]{2}{*}{ Reach } & \multicolumn{4}{|c|}{ Survey Data Points } & \multirow{2}{*}{$\begin{array}{c}\text { Trench } \\
\text { Samples }^{2}\end{array}$} & \multirow{2}{*}{$\begin{array}{l}\text { Painted } \\
\text { Rocks }^{3}\end{array}$} \\
\hline & $\begin{array}{l}\text { Ground } \\
\text { Points }\end{array}$ & $\begin{array}{c}\text { Cross } \\
\text { section }\end{array}$ & $\begin{array}{l}\text { Vegetation } \\
\text { Plots }\end{array}$ & $\begin{array}{l}\text { Bathy- } \\
\text { metric }^{1}\end{array}$ & & \\
\hline Wade and Curtis & 1,560 & 177 & 61 & 6,034 & $3(11)$ & $6 / 10$ \\
\hline Winnie’s & 2,846 & 144 & 59 & 6,786 & $2(12)$ & $7 / 8$ \\
\hline RM233 & 2,851 & 232 & 54 & 5,328 & $3(10)$ & $6 / 9$ \\
\hline Triplet & 1,483 & 212 & 72 & 4,524 & $1(7)$ & $7 / 8$ \\
\hline Limestone Island & -- & -- & -- & -- & -- & $3 / 8$ \\
\hline Total & 8,740 & 765 & 246 & 22,672 & $9(40)$ & $29 / 43$ \\
\hline
\end{tabular}




\section{Cross-Section Data}

We extracted cross sections for each reach from the DEM and/or TIN surfaces. Extraction of cross-section data from either type of data produces similar results. A statistical comparison of a subset of 6 cross sections showed subcentimeter differences in average bed elevation determined from the 2 datasets with a RMSE of $0.007 \mathrm{~m}$ and a MAE of $0.005 \mathrm{~m}$. We used the DEM in most cases. However, extraction of data using the TIN surface was simpler in those cases where the DEM only covered a part of the cross section or near the DEM boundary; thus, the TIN surface covered a slightly larger area in these cases. In both cases, data from individual crosssection points were checked directly against the field data to ensure the accuracy of the digitally extracted data. Additionally, points near the cross-section end points were compared to previous surveys; these points are not expected to vary significantly from year to year, and previous survey data provided a further check on the accuracy of the extracted channel topography. In some cases, cross-section data extended beyond the range of the DEM/TIN coverage. Here, we simply appended the raw survey points to those extracted from the DEM/TIN using the measure tool in ArcGIS ${ }^{\circledR}$. For five cross sections, bathymetric data were not available for the full section as a result of flow conditions that prevented stable boat traverse, and thus, in these five cases, we assumed the bottom topography followed the 2006 surveys. For cross sections 7 and 8 in the Triplet reach, missing bottom topography was sufficiently extensive to preclude evaluation of cross-section change.

\section{Cross-Section Change Analysis}

We compared the cross sections surveyed in 2011 to previous surveys that were established between 1994 and 2001. A minimum of four repeat surveys of each cross section have been made, and all cross sections were surveyed in 2006 and 2011 (table 1). In previous surveys, channel bathymetry was measured using fathometer readings spaced roughly 1-5 $\mathrm{m}$ apart at each transect, and these data were coupled to ground surveys using a total station. In some cases, data gaps in the cross sections were filled with elevation data from previous surveys, but only where topographic change was deemed to be insignificant, for example, above high-water or on stable boulders. This was necessary, because survey protocols differed slightly among years. As a result, changes in bed elevation and channel area computed in the data analysis cover an identical spatial extent for each survey date.

Alexander (2007) summarized cross-section change for three geomorphic zones. These three zones were (1) the active channel bed corresponding to the region below the typical baseflow discharge of $22 \mathrm{~m}^{3} / \mathrm{s}$, (2) the fluctuating-flow zone between the stage of base-flow discharge and the stage of powerplant capacity releases $\left(130 \mathrm{~m}^{3} / \mathrm{s}\right)$, and (3) the flood zone corresponding to deposits above the $130 \mathrm{~m}^{3} / \mathrm{s}$ stage and inundated only during controlled floods (fig. 6). Thus, zone 1 corresponds to changes in elevation of the main-channel bed and may involve either fine sediment or gravel. Zones 2 and 3 correspond to changes in channel-margin or eddy sandbar elevation, which dominantly reflect fine-sediment deposition or erosion on these higher surfaces. Stage-discharge relations for each cross section were determined from field measurements at each cross section for a range of flows, including the maximum stage of the 2011 flood. Stage heights were interpolated to the 22 and $130 \mathrm{~m}^{3} / \mathrm{s}$ discharge stages using a stagedischarge relation of the form

$$
h=a Q^{b},
$$

$\begin{array}{ll}\text { where } & \text { is the stage height in meters, } \\ Q & \text { is discharge in } \mathrm{m}^{3} / \mathrm{s} \text {, and } \\ a & \text { is a coefficient and } \\ b & \text { is an exponent, respectively. }\end{array}$

Although this relation may vary as a function of bed scour or deposition, these relations are typically quite stable in debrisflow dominated canyons, because the rapids that create the hydraulic controls are typically stable. In all cases, we converted stage and cross-section heights to elevations above the NAD83 ellipsoid using the geodetic control from 2011 and the measured offset from surveyed benchmarks.

Within each zone, we computed changes in channel cross-section area, for each survey, relative to that measured in 2006 in zones 1, 2, and 3 (fig. 6). Because the cross sections were not spaced closely enough to accurately calculate changes in total sediment volume, we interpreted the change in cross-section area as a surrogate for change in sediment volume. Decreases in cross-section area indicate deposition, and increases indicate erosion. The reasons for choosing 2006 as the reference survey were two-fold. Foremost, all of the cross sections were surveyed in 2006 during a short time span (table 1), providing a basis for trend analysis among all locations. Second, this report follows the analysis of Alexander (2007), who established similar trends in relation to the flow regime up to 2006. As such, a primary purpose of the data collected in 2011 was to extend Alexander's (2007) analysis to include the 2011 flood.

Changes at each cross section are also reported in terms of change in bed elevation and in deposit thickness. Although the changes in bed elevation were generally consistent with the changes in cross-section area, they provide a more intuitive scaling of the data while normalizing for the width of a given deposit. We computed changes in bed elevation as the change in cross-section area divided by the time-averaged top width in each zone as measured over the survey record (fig. 6). Although these widths vary among surveys, the time-average provides a constant scaling factor reflecting typical conditions, and the sum of the average width of each zone is equivalent to the total cross-section width and is essentially constant over time.

There is the potential to bias results using a subsampling scheme based on changes at individual cross sections at a subset of reaches. The four study reaches were chosen to 


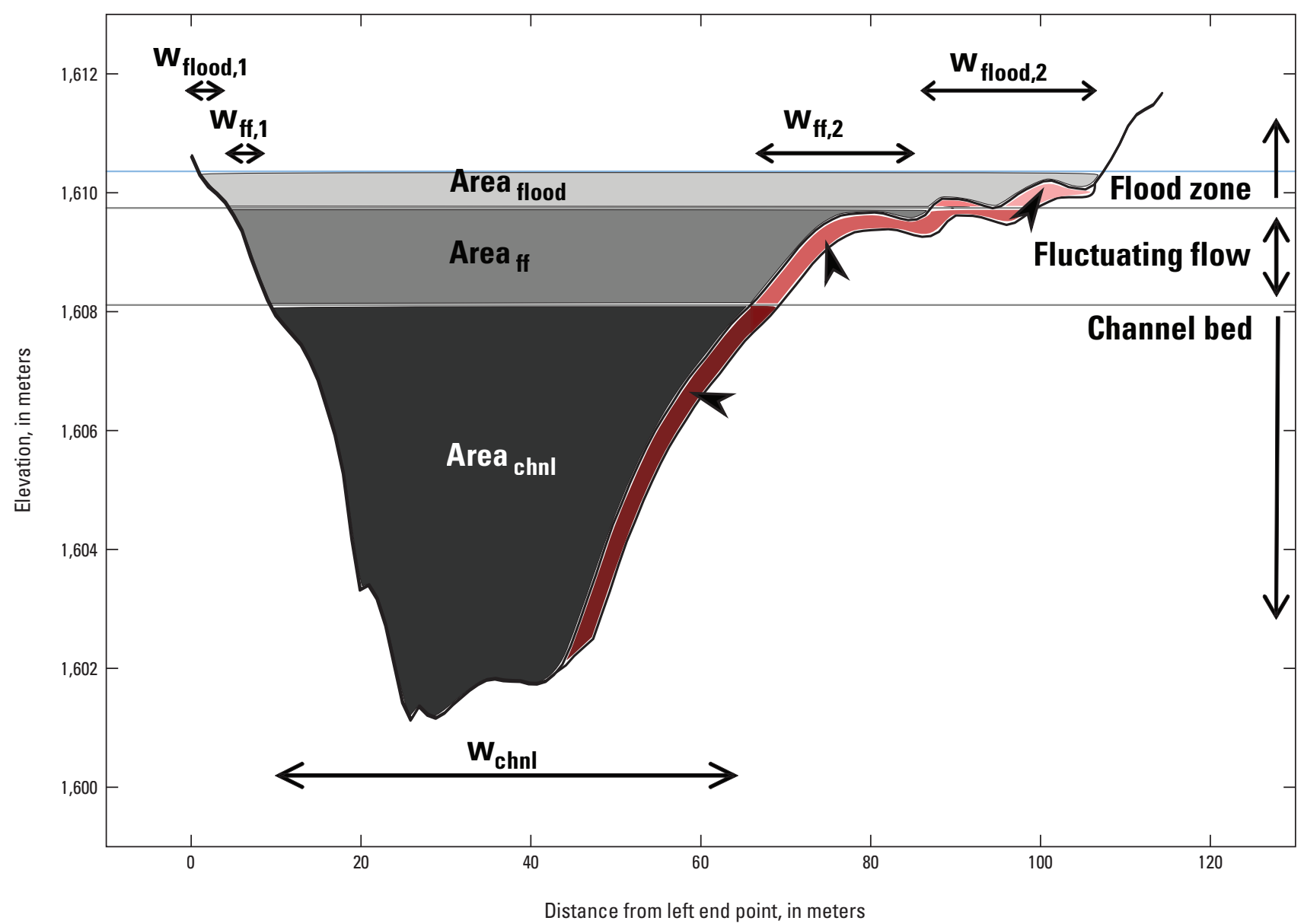

Figure 6. Methods used to calculate changes in cross-section area and bed elevation at monumented cross sections based on repeated surveys of the Green River in the Canyon of Lodore, Dinosaur National Monument, Colorado and Utah. Widths of the flood, fluctuating flow, and channel zones are given as $\mathrm{w}_{\text {flood }}, \mathrm{w}_{\mathrm{fft}}$ and $\mathrm{w}_{\text {chnl' }}$ and subscripts 1 and 2 represent the river left and right parts of the flood and fluctuating zones, respectively. Areas of the flood, fluctuating flow, and channel zones are given as Area $_{\text {flood }^{\prime}}$ Area $_{\mathrm{ff}^{\prime}}$ and Area $_{\text {chnl }}{ }^{*}$

represent typical fan-eddy complexes, the primary geomorphic unit in Lodore Canyon. Within each study reach, cross sections were spaced relatively evenly upstream and downstream from the primary channel-constricting debris flow. In general, four to six cross sections encompass the full extent of the upstream pool and associated fine sediment deposits, with the remaining four to six cross sections covering parts of the downstream expansion pool and gravel bar (see figures 9-12, appendix 1). We believe that the cross sections provide a reasonably accurate representation of the magnitude and distribution of erosion and deposition within each study reach. There is, however, greater uncertainty in the degree to which the selected study reaches are representative of other faneddy complexes in Lodore Canyon. Grams and others (2013) showed that changes in a single fan-eddy complex could be of different magnitude and sign than reach-average changes in sediment storage. The cumulative length of the study reaches is approximately $3.5 \mathrm{~km}$, representing a sample of about 10 to 15 percent of the study area between Gates of Lodore and Echo Park. The cross-section change analysis thus provides a spatial and temporal picture of change in each reach but does not necessarily capture the range of change in all reaches throughout the canyon. We discuss in detail the local- to reachscale variability in response at the study reaches, and thus, the potential for bias due to site selection in the context of the 2011 geomorphic response described below.

\section{Trench Stratigraphy and Sedimentology}

Nine trenches were dug at various locations in recently reworked sandbars in the four primary study reaches (table 2). Trench stratigraphy and sedimentology reflect depositional processes influenced by both local channel hydraulics and large-scale sediment supply (Rubin and others, 1990; Rubin and others, 1998; Rubin and Topping, 2001; Topping and others, 2005). Additionally, trench analysis provides a means to distinguish the thickness of sandbar deposition during the 2011 controlled flood from preexisting deposits. Grain size from the trench samples was determined through traditional methods and image analysis using a "beach ball" camera (Rubin and 
others, 2007). Traditional methods involve drying the samples and sieving through a series of 0.25 -phi $(\phi)$ mesh increments using standard 8-inch sieves in a Tyler RO-TAP shaker (Topping and others, 2010). Image analysis computes grain size using statistical properties that relate grain size to the image texture or pixel intensity (Rubin, 2004). More recently, the technique has evolved to become more generic. On the basis of image power spectra, Buscombe and others (2010) developed a calibration-free technique, but this technique provides only the mean and standard deviation of the grain size distribution. Here, we use the most recent version of this approach, which uses a wavelet method to provide a calibration-free estimate of the entire size distribution (Buscombe, 2013). MAE for natural sediment associated with this technique range from 11 percent for the median grain size to greater than 20 percent for the tails of the distribution (10th and 90th percentiles). These automated methods are particularly sensitive to detecting the size of surface grains and may give results coarser than grab samples due to winnowing of fine sediments by wind or trench excavation (Rubin and others, 2007).

Images were cropped to remove light stripes from the light-emitting diode (LED) lamps in the waterproof housing; the resulting images were slightly greater than $10 \times 10 \mathrm{~mm}$ in dimension; for a typical grain size, an image of this size contains greater than 1,000 grains. We processed the images in MATLAB ${ }^{\circledR}$ using freely available code (http://github.com/ dbuscombe-usgs/, accessed March 2013). We then converted the grain size distribution from pixels to mm using a scaling ratio of $62 \mathrm{pixel} / \mathrm{mm}$ for the camera used in this analysis (David Rubin, U.S. Geological Survey, written commun., August 2012).

\section{Tracer-Rock Movement}

Tracer-rock studies are a simple and effective way of determining particle motion for coarse bed material (for example, Leopold and others, 1966). Previous work has suggested that flows capable of mobilizing coarse gravel and cobble may represent hydraulic conditions necessary for tamarisk removal (Larson, 2004), a desired management outcome that is much less labor intensive than mechanical removal. Individual particles were painted on parts of exposed gravel bars within each study reach in the early 2000s and reoccupied in 2011. In addition to the four primary study reaches described above, an additional site was reoccupied on Limestone Island at River Mile 227.75 (fig. 1). Each painted rock patch was roughly $1 \times 1 \mathrm{~m}$, and between 8 to 10 patches were painted on a gravel bar in each study reach. Clast size in each patch ranged from pebble to boulder, with most particles concentrated in the cobble-size range (typical distribution from 16 to greater than $256 \mathrm{~mm}$ ). For each patch of painted rocks that was relocated, the proportion of clasts that moved and grain-size of mobile and immobile clasts were measured. Where applicable, the impact of gravel mobility on tamarisk or change in bar configuration was noted. Any particles moved from their initial location were considered mobile, and, where feasible, the distance of movement was documented. For the purposes of this report, painted rock mobility was grouped into four general categories: no movement; minor movement (greater than 90 percent of rocks in place); moderate movement (greater than 50 percent of rocks in place); and major movement (less than 50 percent of rocks in place). We qualitatively estimated these category boundaries. Additionally, burial of the painted rock patches, predominantly by fine sediment, complicated the analysis. We considered that particles moved only when individual particles had been obviously removed from the patch or relocated beyond the initial patch; patches potentially buried were documented as such and not considered to have moved.

\section{Results}

The results presented herein proceed first with a description of the survey control network established during the 2011 surveying campaign in the Canyon of Lodore. We then show the geomorphic change between 2001 and 2011 from DEM differencing, followed by a presentation of the 2011 cross sections extracted from the digital terrain models. Last, we describe the observations of sandbar stratigraphy and tracer rock mobility. Following the results, we present an integrated discussion of the geomorphic effects of the 2011 flood in Lodore Canyon with particular focus on the channel bed and sandbar elevation time-series derived from the crosssection change analysis.

\section{Survey Control Network}

The locations of the rim control stations are shown in figure 1. These published rim stations provide access to the NAD83 datum, and the National Spatial Reference System (NSRS). The GNSS stations along the river corridor are referenced to the rim stations by postprocessed static vectors in an Earth centered-Earth fixed coordinate system. All geodetic positions are then projected into 1983 State Plane coordinate system (Colorado North zone 0501) in meters for field surveys and DEM development. The conventional and optically derived stations are constrained to the GNSS network adjustment results by horizontal and zenith angles and in slope distances.

Published horizontal and vertical accuracy for the passive control stations ranges from $11-23 \mathrm{~mm}$ in the horizontal and 7-0 $\mathrm{mm}$ in ellipsoidal height (95-percent confidence). Results of the GNSS network adjustment of the river corridor stations show accuracies to the datum of less than $20 \mathrm{~mm}$ horizontally and $55 \mathrm{~mm}$ vertically (95-percent confidence, ellipsoid heights). Results of the adjustment of conventional measurements show excellent repeatability with the GNSS positions and were consistent at the 20 -mm horizontal and 30-mm ellipsoidal heights accuracy. Network accuracy and error estimation could be improved with multiple, independent observations. 
A series of benchmarks was established for use as instrument and backsight locations along the four primary study reaches. Figures 7 and 8 show the locations of these control points overlain on high-resolution aerial photos; points with a black triangle were occupied by GNSS, and the remaining points were determined through total station surveys. As part of this project, a detailed channel thread was created using aerial photos and georeferenced to the Colorado State Plane system, consistent with the Belknap (Belknap and Evans, 1993 ) river mile system through the canyon corridor. Control point locations were labeled by their distance, in hundredths of miles, upstream from the Denver and Rio Grande Western Railroad (D\&RGW) bridge in Green River, Utah, with an additional modifier indicating river right $(\mathrm{R})$ or river left $(\mathrm{L})$ when looking downstream. Use of English units in referencing locations throughout the Colorado River system is a longstanding tradition and all modern river guides use this system. Table 3 lists the names, coordinates, and elevations for the control network shown in figures 7 and 8 . The naming system updates and systematizes the benchmark control, but we also include the historical (Utah State University/Northern Arizona University) naming system in the comments column (table 3). It is important to note that the naming convention here was forced to fit the commonly used Belknap (Belknap and Evans, 1993) system, and these distances do not exactly represent a true distance measured along the digitized channel thread. A link to field data for this study posted on the USGS Grand Canyon Monitoring and Research Center (GCMRC) Web site, including coordinates, aerial photos, and ground photos of cross-section locations, as well as associated coordinates of vegetation plots from 2011, is available at http://pubs.usgs. gov/sir/2014/5022/.

\section{Reach-Scale Surveys and Digital Elevation Models}

Table 2 summarizes the survey point density for each reach, and figures 9-12 are maps of survey point locations and the corresponding DEMs for each of the four reaches. Ground surveys focused on bars, channel margins, and areas of rapid topographic change such as channel bank edges. Bathymetric survey data were collected in those parts of the channel safely navigable by boat during operation of the single-beam sonar. For the Wade and Curtis, Winnies, and Triplet reaches, the DEMs show a deep pool and associated eddy deposits in the upstream part of the reach (figs. 9, 10, 12). In contrast, the upstream part of the RM233 reach has a flat bed and does not have any large eddies along the banks (fig. 11). Downstream from the primary debris fan, all reaches tend to have relatively deep pools with associated gravel bars and zones of flow recirculation. Rapids were not surveyed. Rapids do not change significantly during floods except when they have recently been aggraded (Larsen and others, 2003), and no significant recent debris flows occurred in the study reaches during the study period.

\section{DEMs of Difference}

Although the bathymetric data collected in 2011 are much more detailed than the previous datasets, the banks and bars were surveyed at comparable resolution in 2001 and 2011. These data provide an indication of decadal-scale change at these reaches (figs. 13 and 14) and are used to supplement our analysis of the 2011 flood effects discussed in more detail below. The histograms inset in each plot summarize the area of each study reach where topographic changes of different magnitudes occurred. These data indicate that topographic changes were less than the minimum level of detection $( \pm 0.25 \mathrm{~m})$ in most of each reach but that there were areas of localized erosion and deposition greater than $2 \mathrm{~m}$ in some places. The Wade and Curtis and Winnies reaches show minor bank erosion of the vegetated active floodplain in the ponded backwaters upstream from their respective debris fans. In the active channel, there was significant sandbar deposition in eddies in the upstream and downstream parts of the Winnies reach (fig. 13B) and sandbar erosion in the Wade and Curtis reach (fig. 13A). The sandbar erosion in the Wade and Curtis reach likely reflects the downstream translation of eddy bars in the upstream pool during the 2011 flood (see discussion below). Geomorphic change between 2001 and 2011 was less distinct in the RM233 and Triplet reaches; most topographic change involved aggradation along the banks and little bank erosion (fig. 14). In all cases, the topography of gravel bars did not significantly change, except for some minor fine sediment deposition on their surfaces (figs. 13 and 14).

\section{Cross-Section Data}

The channel cross sections provide greater temporal resolution for small parts of each reach. Selected cross sections for each study reach are shown in figures 9-12; data from 2011 at all eight cross sections for each study reach are included in appendix 3 (figs. 3.1-3.4). Flow depth during the 2011 flood ranged from greater than $10 \mathrm{~m}$ in some sections, to less than 3-4 $\mathrm{m}$ in others. This reflects the spacing of the cross-section data across the range in channel topography of a typical fan-eddy complex in Lodore Canyon. Topographic change at these cross sections during the period of observation thus provides a longer-term assessment of channel adjustment in Lodore Canyon. We present these results in detail below in the context of the 2011 controlled flood.

\section{Trench Stratigraphy and Sedimentology}

Previous workers have shown that changes in the vertical sequence of grains in flood deposits are indicative of temporal changes in sediment supply, and that the grain size of sandbars is similar to that carried in suspension during flood events (Rubin and others, 1998; Rubin and Topping, 2001; Topping and others, 2005, 2007, 2010). The data from trench analysis in this study show mixed results, and are difficult to 


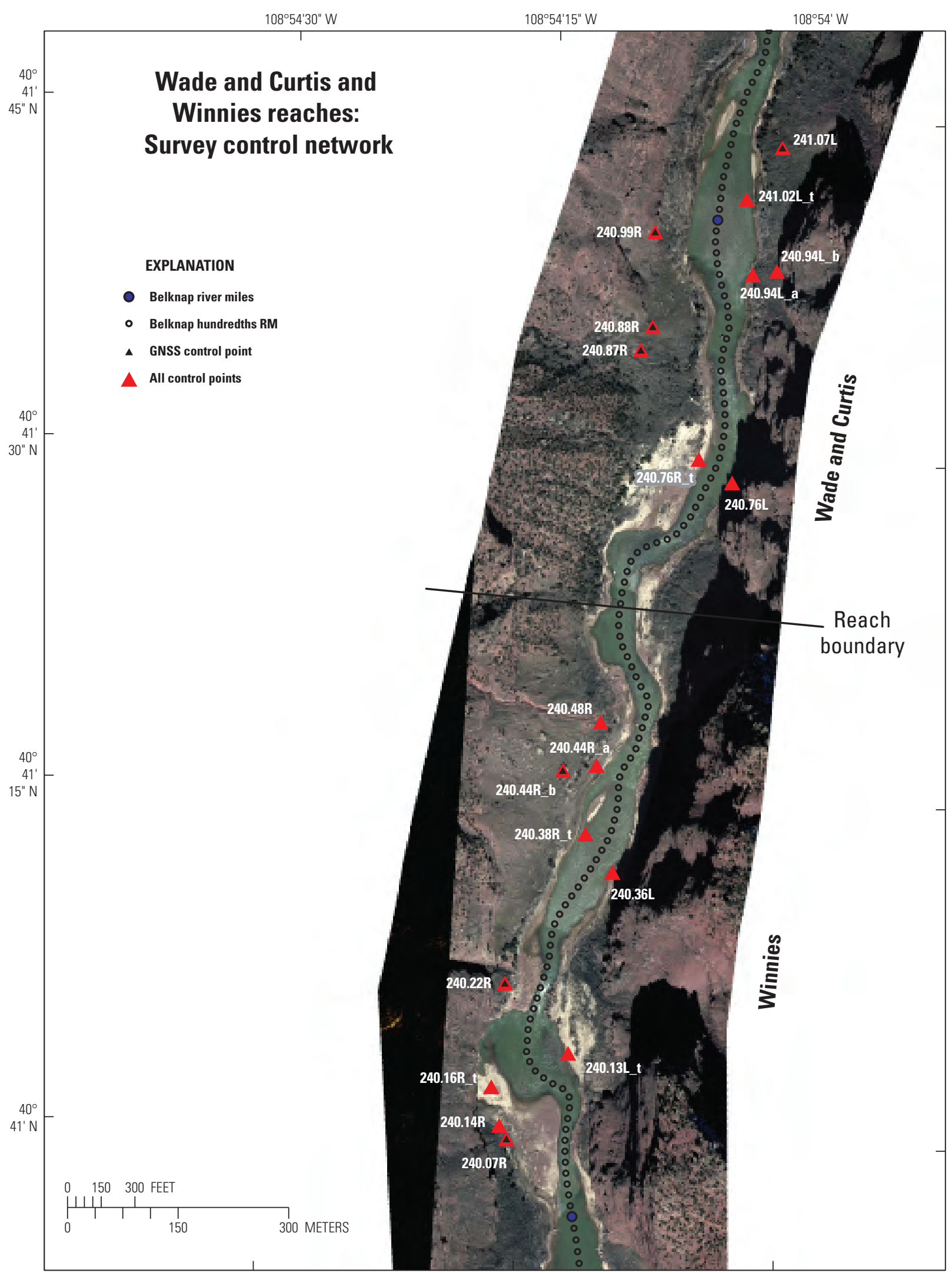

State Plane, Colorado north zone 0501 NAD 1983 (NSRS 2007). Orthophotos acquired 2005.

Figure 7. Survey control network for the Wade and Curtis and Winnies reaches on the Green River in Canyon of Lodore, Dinosaur National Monument, Colorado and Utah. Coordinates for individual points are given in table 1. Streamflow is from north to south. GNSS, Global Navigation Satellite System; RM, river mile. 


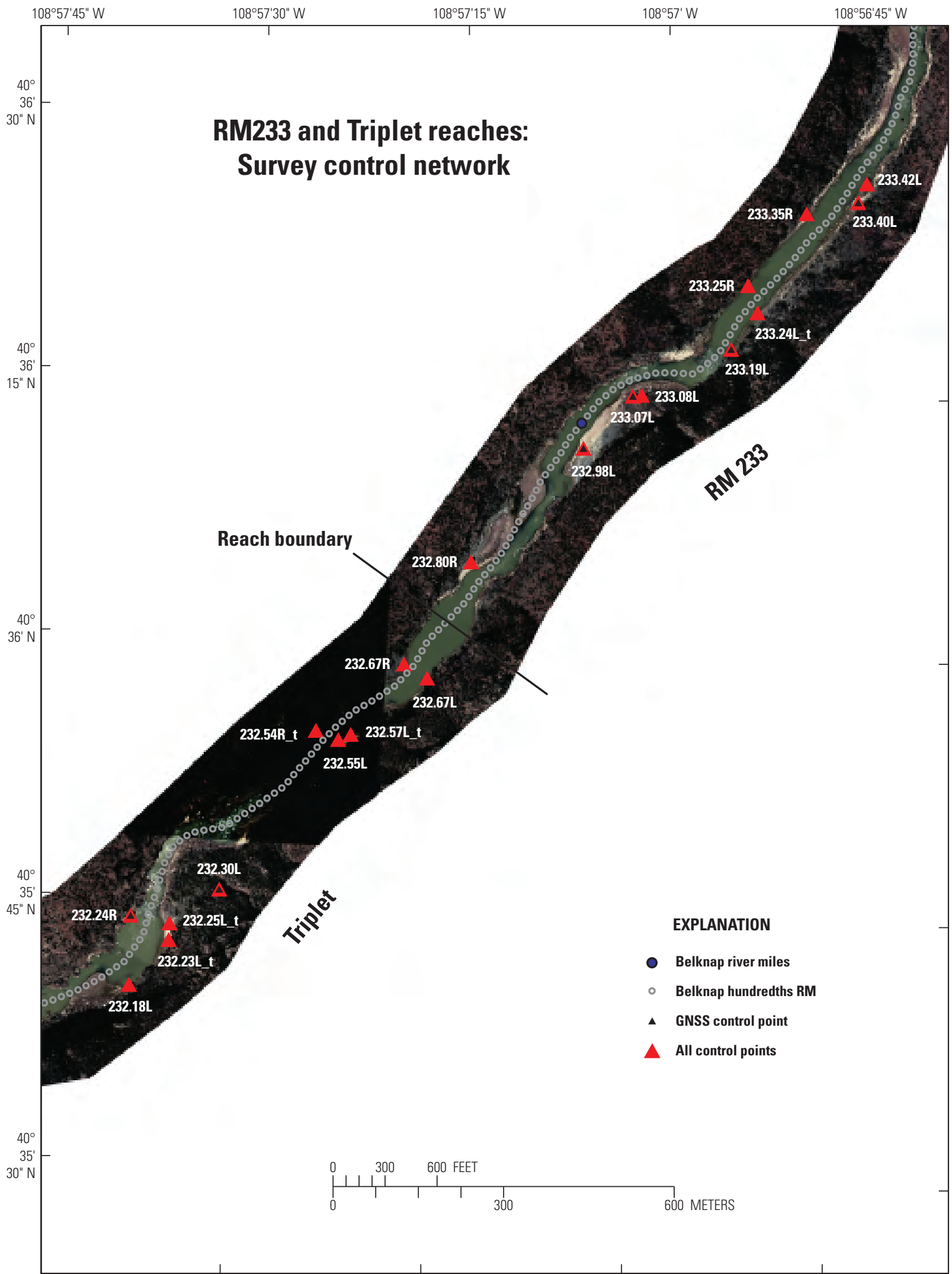

State Plane, Colorado north zone 0501 NAD 1983 (NSRS 2007) Orthophotos acquired 2005

Figure 8. Survey control network for the RM233 and Triplet reaches on the Green River in Canyon of Lodore, Dinosaur National Monument, Colorado and Utah. Coordinates for individual points are given in table 1. Streamflow is from north to south. GNSS, Global Navigation Satellite System; RM, river mile. 


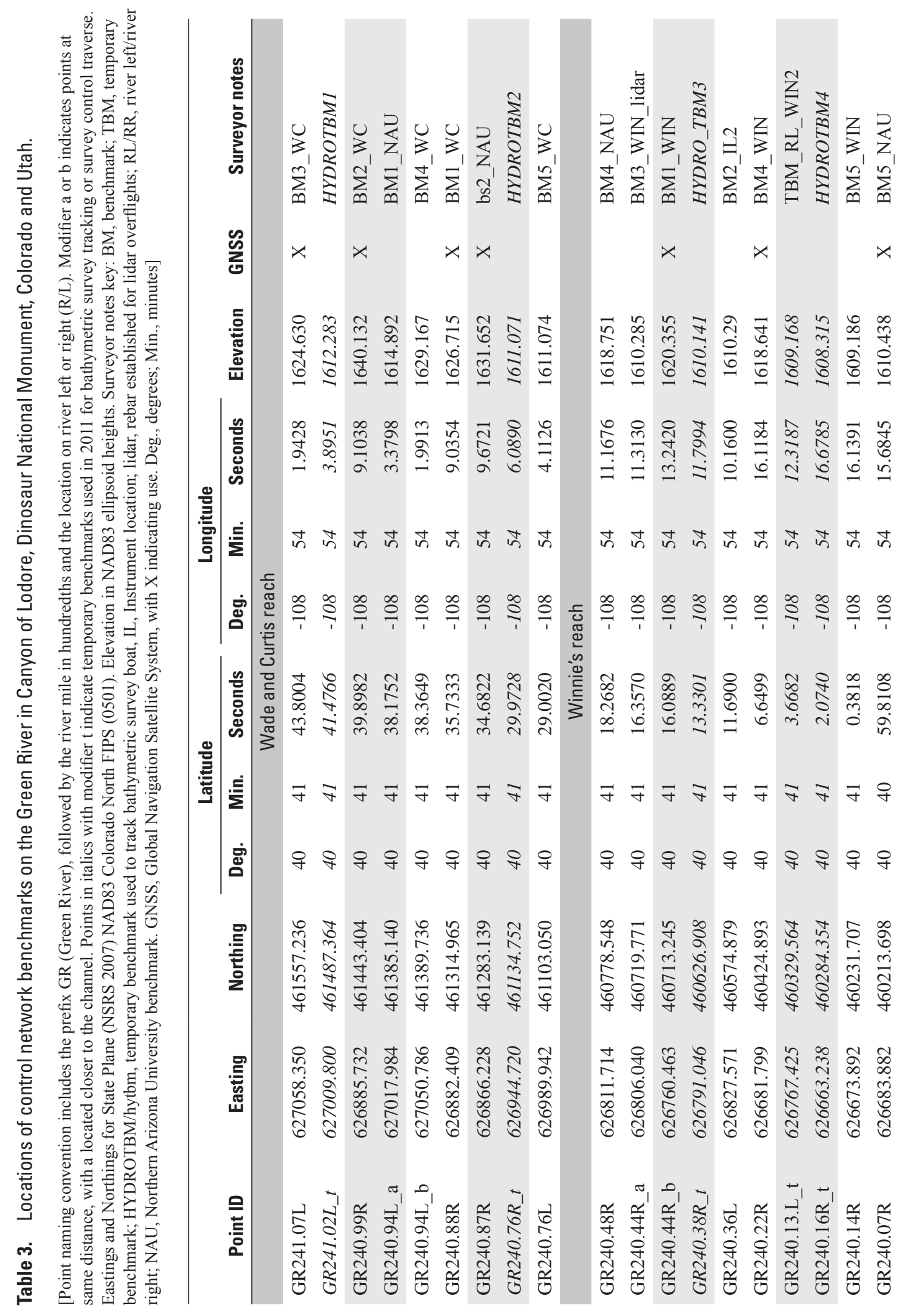




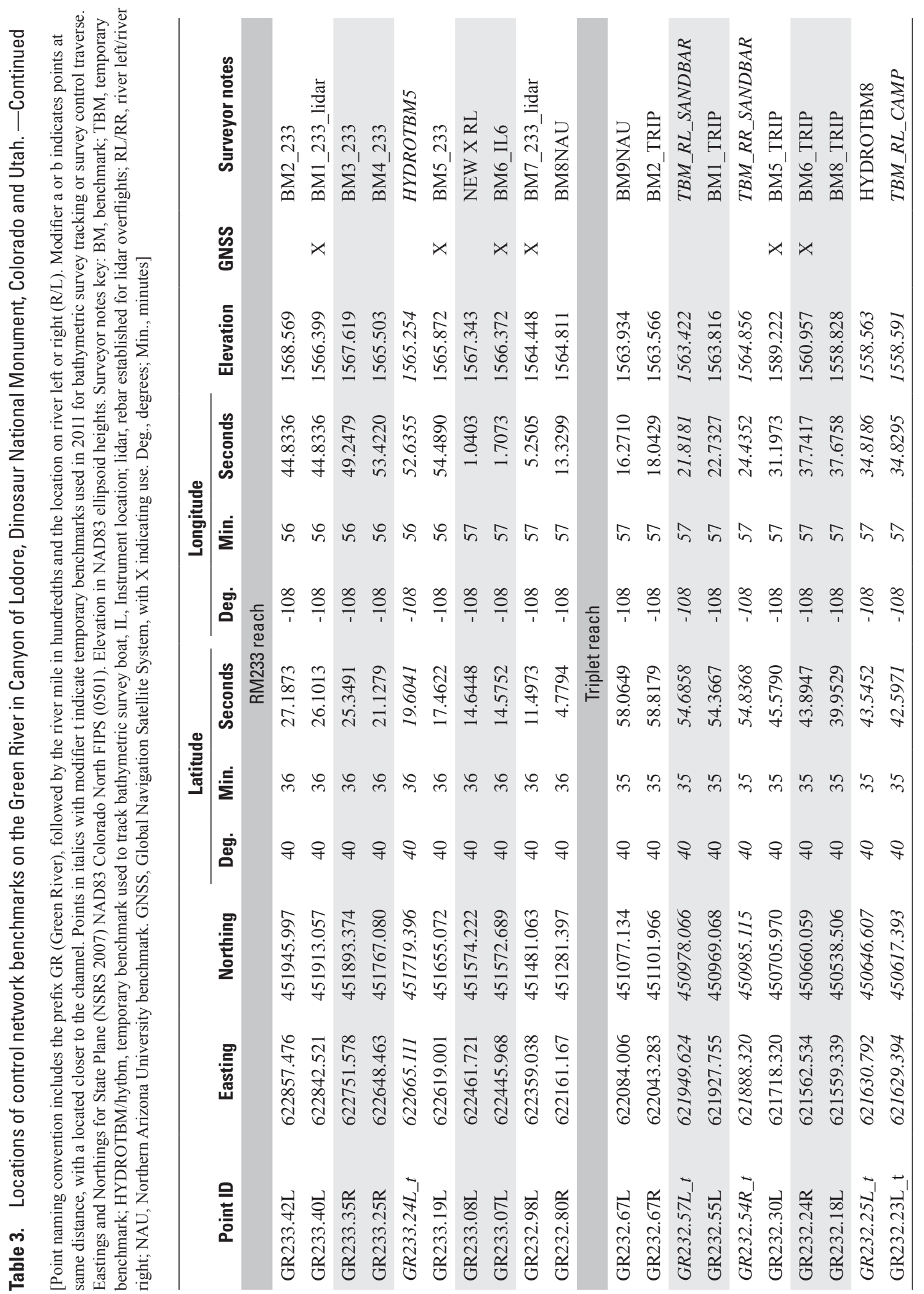




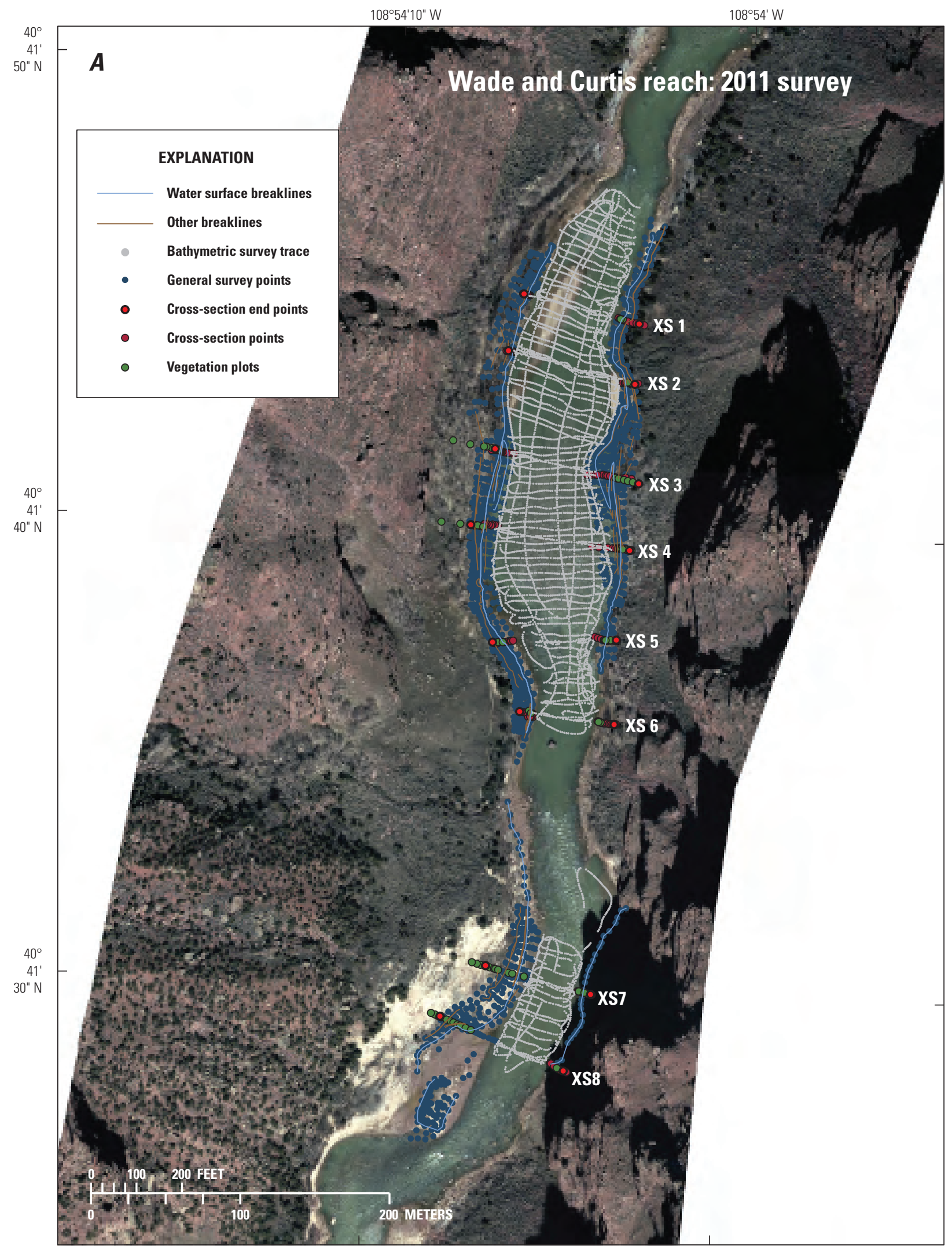

State Plane, Colorado north zone 0501 NAD 1983 (NSRS 2007). Orthophotos acquired 2005.

Figure 9. The Wade and Curtis reach on the Green River in Canyon of Lodore, Dinosaur National Monument, Colorado and Utah. $A$, survey points; $B, 1$-meter digital elevation model (DEM) derived from triangular irregular network (TIN) surface. The letters indicate geomorphic characteristics referred to in the discussion: S, scour pool; EB, eddy bar; GB, gravel bar; XS, cross section. Streamflow is from north to south. 


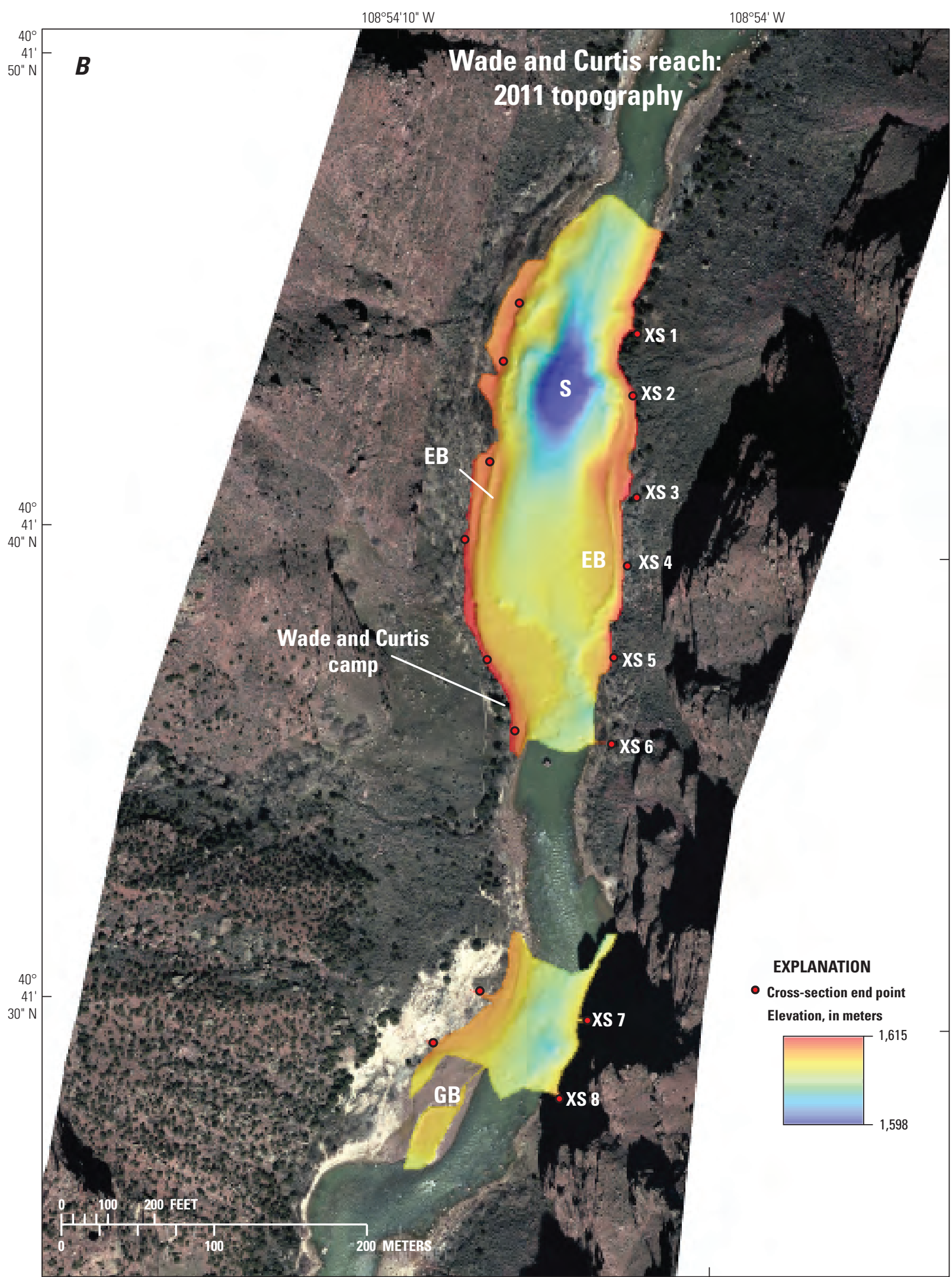

State Plane, Colorado north zone 0501 NAD 1983 (NSRS 2007) Orthophotos acquired 2005

Figure 9. The Wade and Curtis reach on the Green River in Canyon of Lodore, Dinosaur National Monument, Colorado and Utah. $A$, survey points; $B$, 1-meter digital elevation model (DEM) derived from triangular irregular network (TIN) surface. The letters indic ate geomorphic characteristics referred to in the discussion: S, scour pool; EB, eddy bar; GB, gravel bar; XS, cross section. Streamflow is from north to south. - Continued 


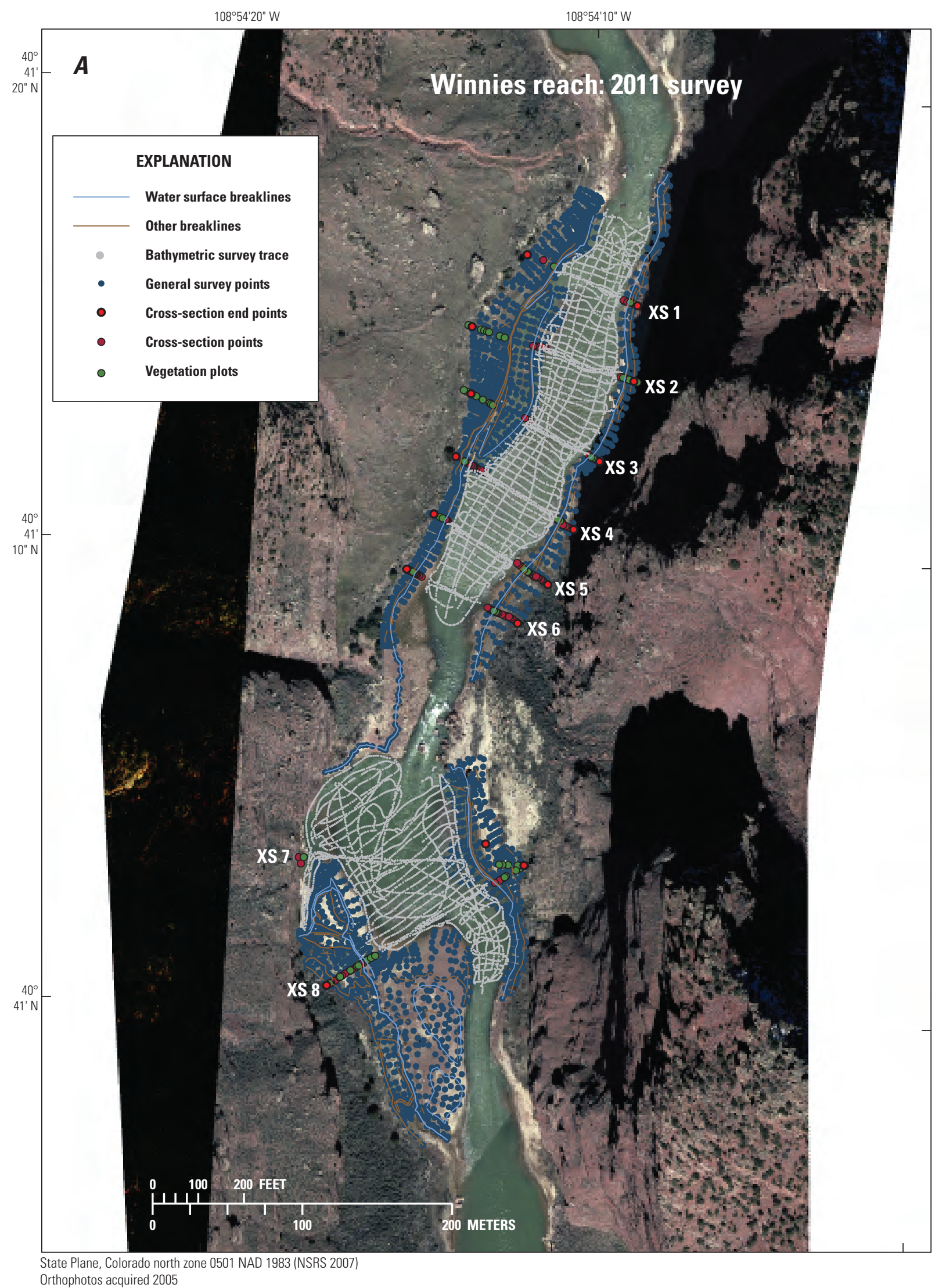

Figure 10. Winnies reach on the Green River in Canyon of Lodore, Dinosaur National Monument, Colorado and Utah. $A$, survey points; $B$, 1-meter digital elevation model (DEM) derived from triangular irregular network (TIN) surface. The letters indicate geomorphic characteristics referred to in the discussion: $\mathrm{S}$, scour pool; EB, eddy bar; GB, gravel bar; XS, cross section. Streamflow is from north to south. 


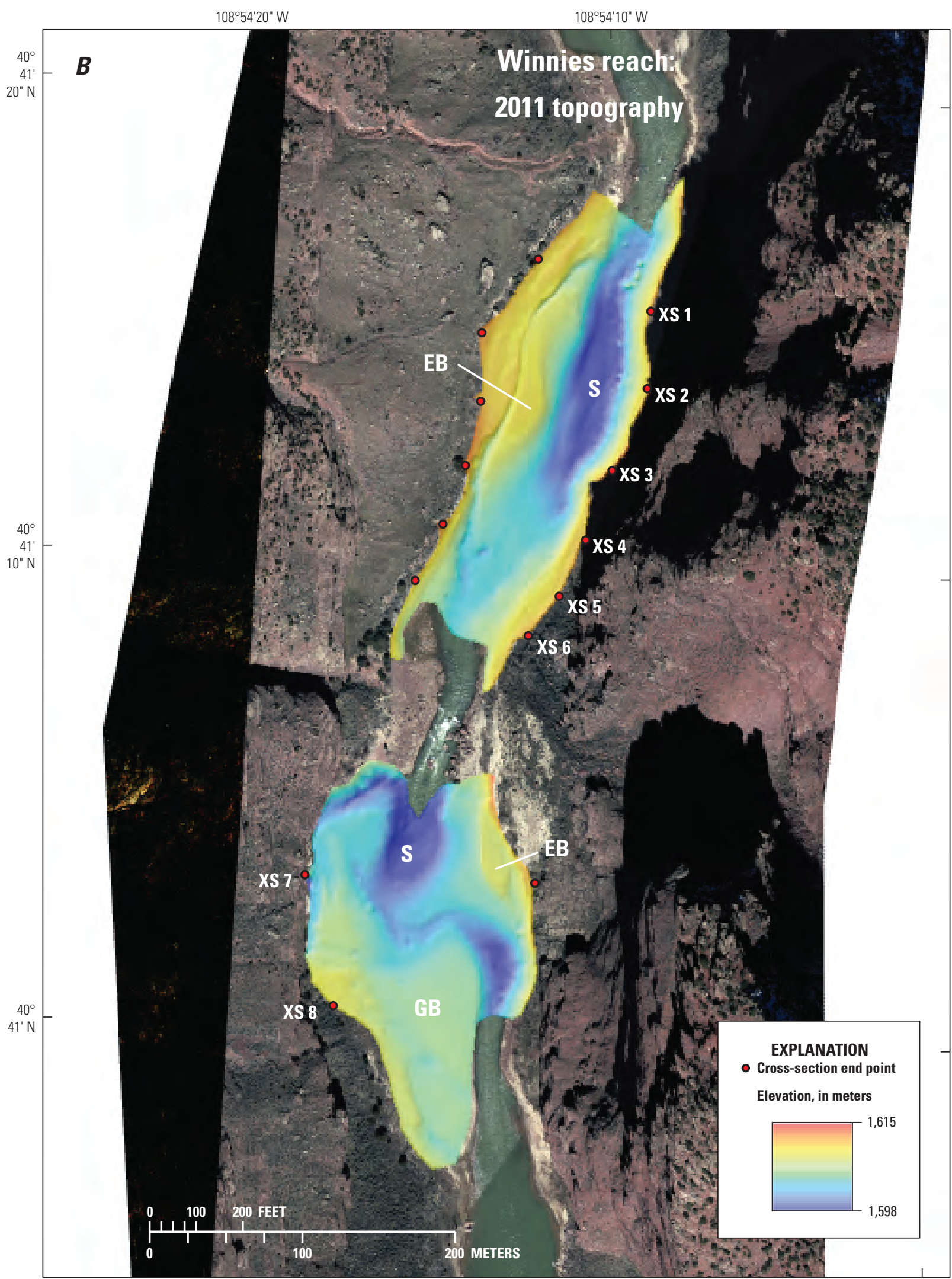

State Plane, Colorado north zone 0501 NAD 1983 (NSRS 2007) Orthophotos acquired 2005

Figure 10. Winnies reach on the Green River in Canyon of Lodore, Dinosaur National Monument, Colorado and Utah. $A$, Survey points; $B$, 1-meter digital elevation model (DEM) derived from triangular irregular network (TIN) surface. The letters indicate geomorphic characteristics referred to in the discussion: $\mathrm{S}$, scour pool; EB, eddy bar; GB, gravel bar; XS, cross section. Streamflow is from north to south. - Continued 


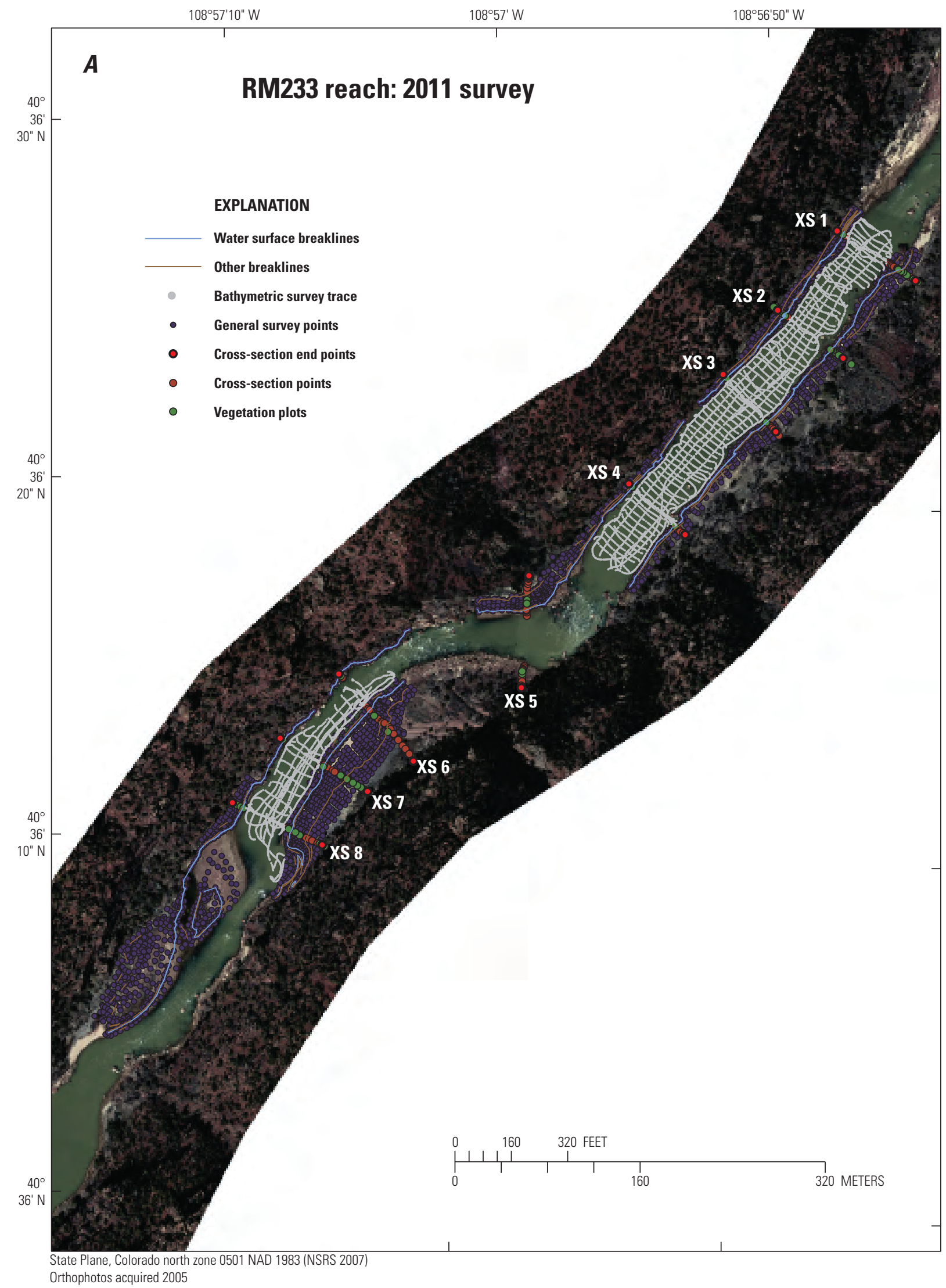

Figure 11. RM233 reach on the Green River in Canyon of Lodore, Dinosaur National Monument, Colorado and Utah. $A$, survey points; $B$, 1-meter digital elevation model (DEM) derived from triangular irregular network (TIN) surface. The letters indicate geomorphic characteristics referred to in the discussion: $\mathrm{S}$, scour pool; EB, eddy bar; CM, channel-margin deposit; GB, gravel bar; XS, cross section. Streamflow is from northeast to southwest. 


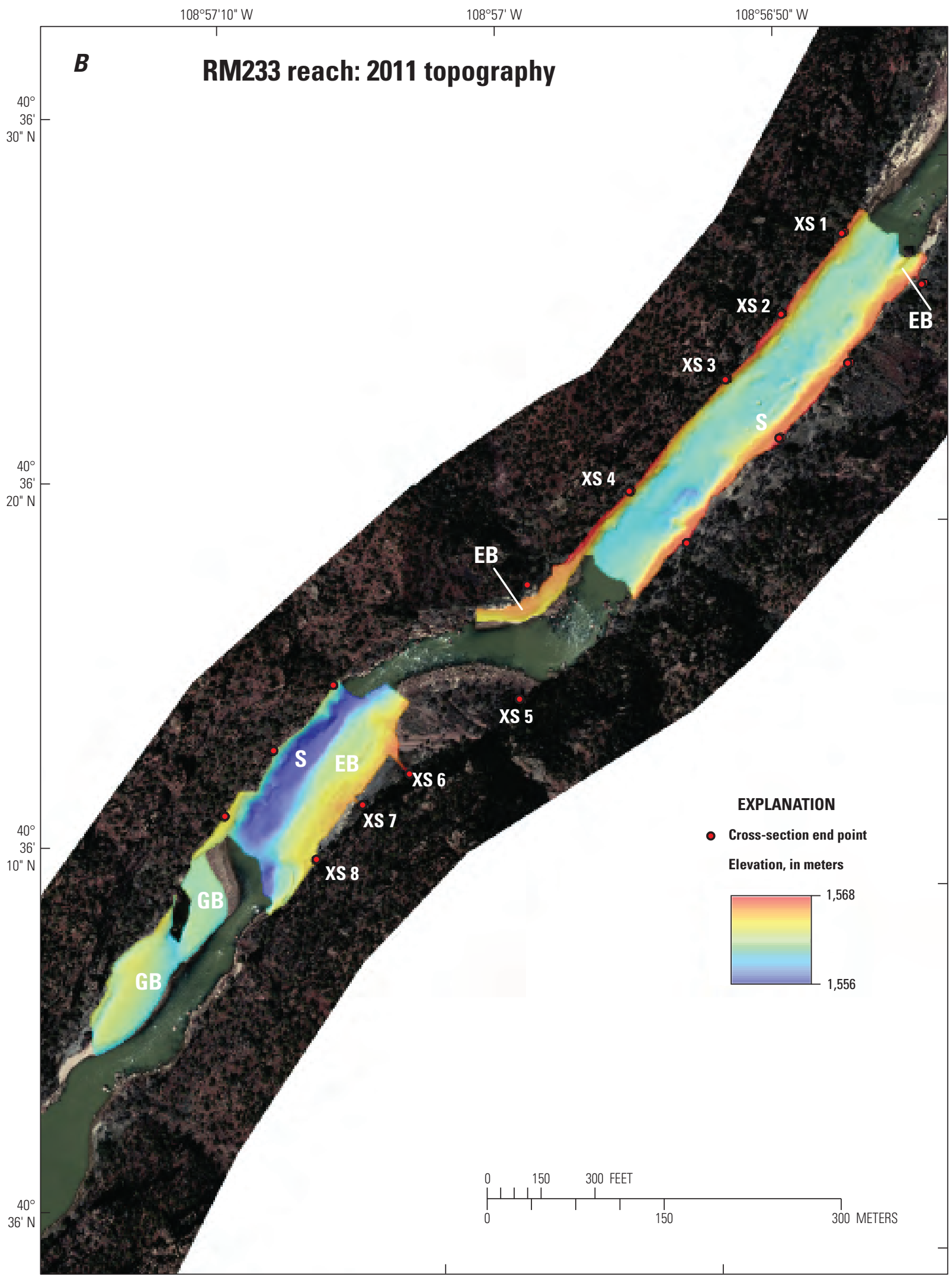

State Plane, Colorado north zone 0501 NAD 1983 (NSRS 2007). Orthophotos acquired 2005

Figure 11. RM233 reach on the Green River in Canyon of Lodore, Dinosaur National Monument, Colorado and Utah. $A$, Survey points; $B$, 1-meter digital elevation model (DEM) derived from triangular irregular network (TIN) surface. The letters indicate geomorphic characteristics referred to in the discussion: $\mathrm{S}$, scour pool; EB, eddy bar; $\mathrm{CM}$, channel-margin deposit; GB, gravel bar; XS, cross section. Streamflow is from northeast to southwest. - Continued 


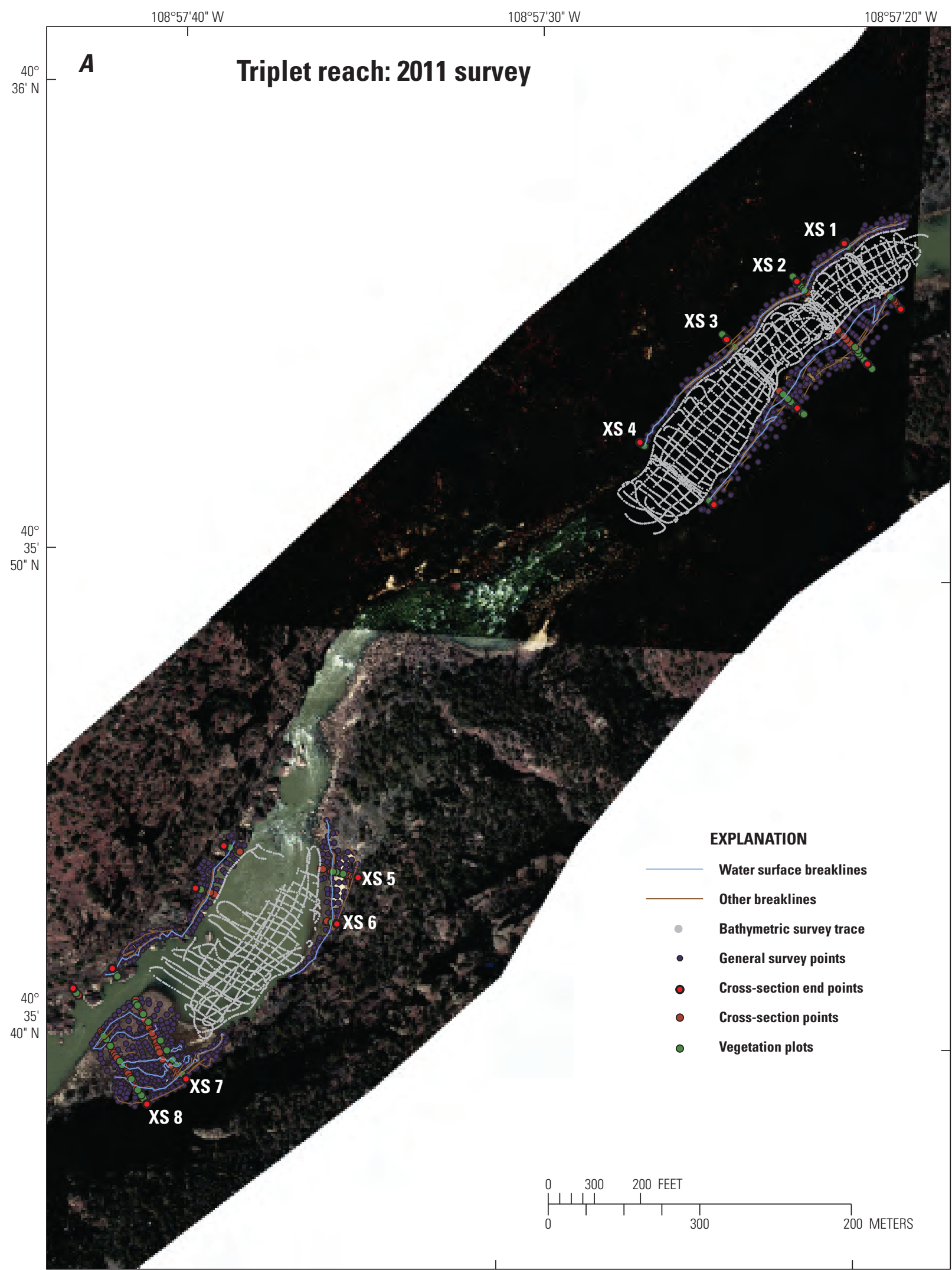

State Plane, Colorado north zone 0501 NAD 1983 (NSRS 2007).

Orthophotos acquired 2005

Figure 12. Triplet reach on the Green River in Canyon of Lodore, Dinosaur National Monument, Colorado and Utah. $A$, survey points; $B$, 1-meter digital elevation model (DEM) derived from triangular irregular network (TIN) surface. The letters indicate geomorphic characteristics referred to in the discussion: S, scour pool; EB, eddy bar; GB, gravel bar; XS, cross section. Streamflow is from northeast to southwest. 


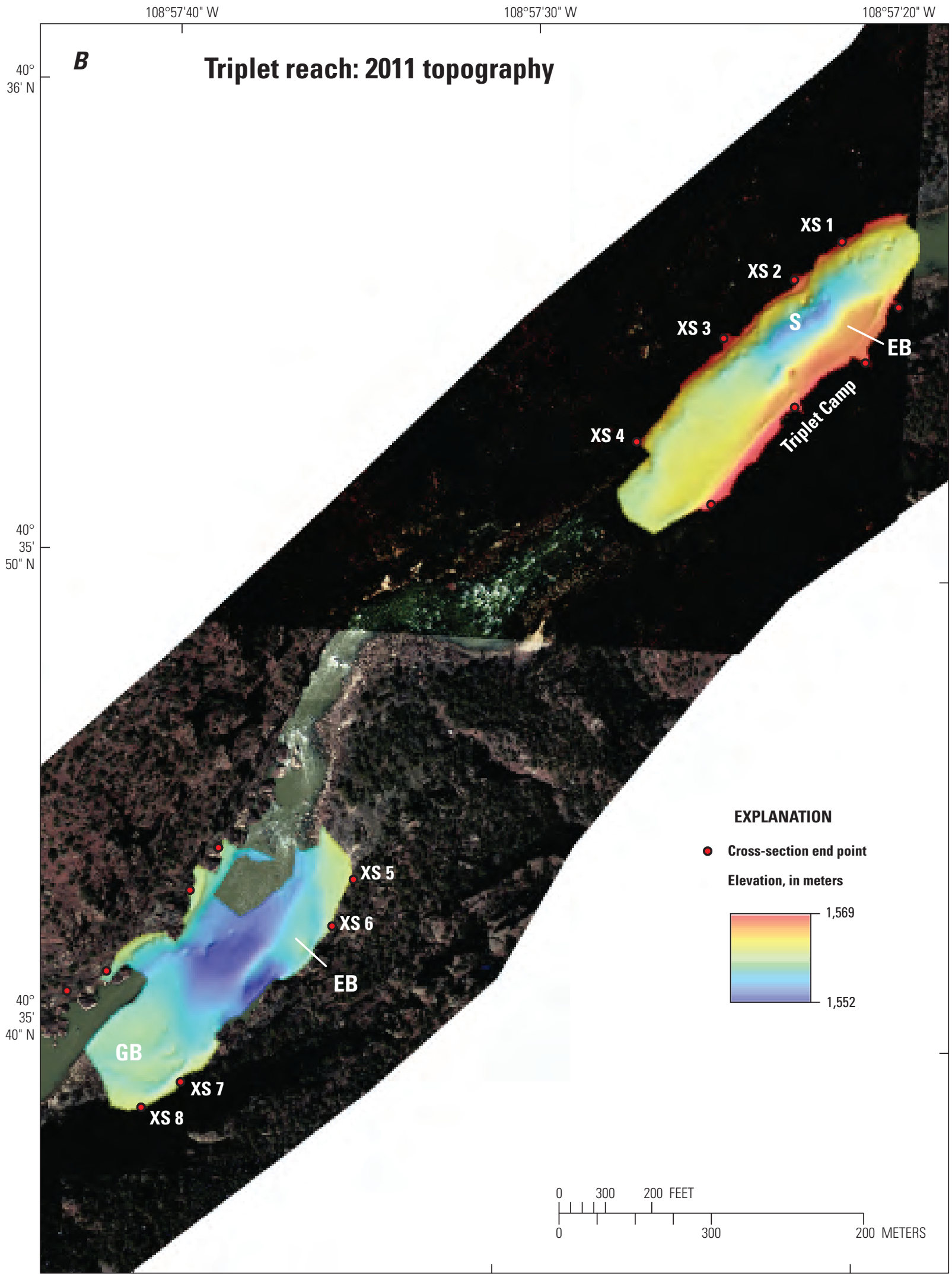

State Plane, Colorado north zone 0501 NAD 1983 (NSRS 2007).

Orthophotos acquired 2005.

Figure 12. Triplet reach on the Green River in Canyon of Lodore, Dinosaur National Monument, Colorado and Utah. A, Survey points; $B, 1$-meter digital elevation model (DEM) derived from triangular irregular network (TIN) surface. The letters indicate geomorphic characteristics referred to in the discussion: $\mathrm{S}$, scour pool; EB, eddy bar; GB, gravel bar; XS, cross section. Streamflow is from northeast to southwest. —Continued 


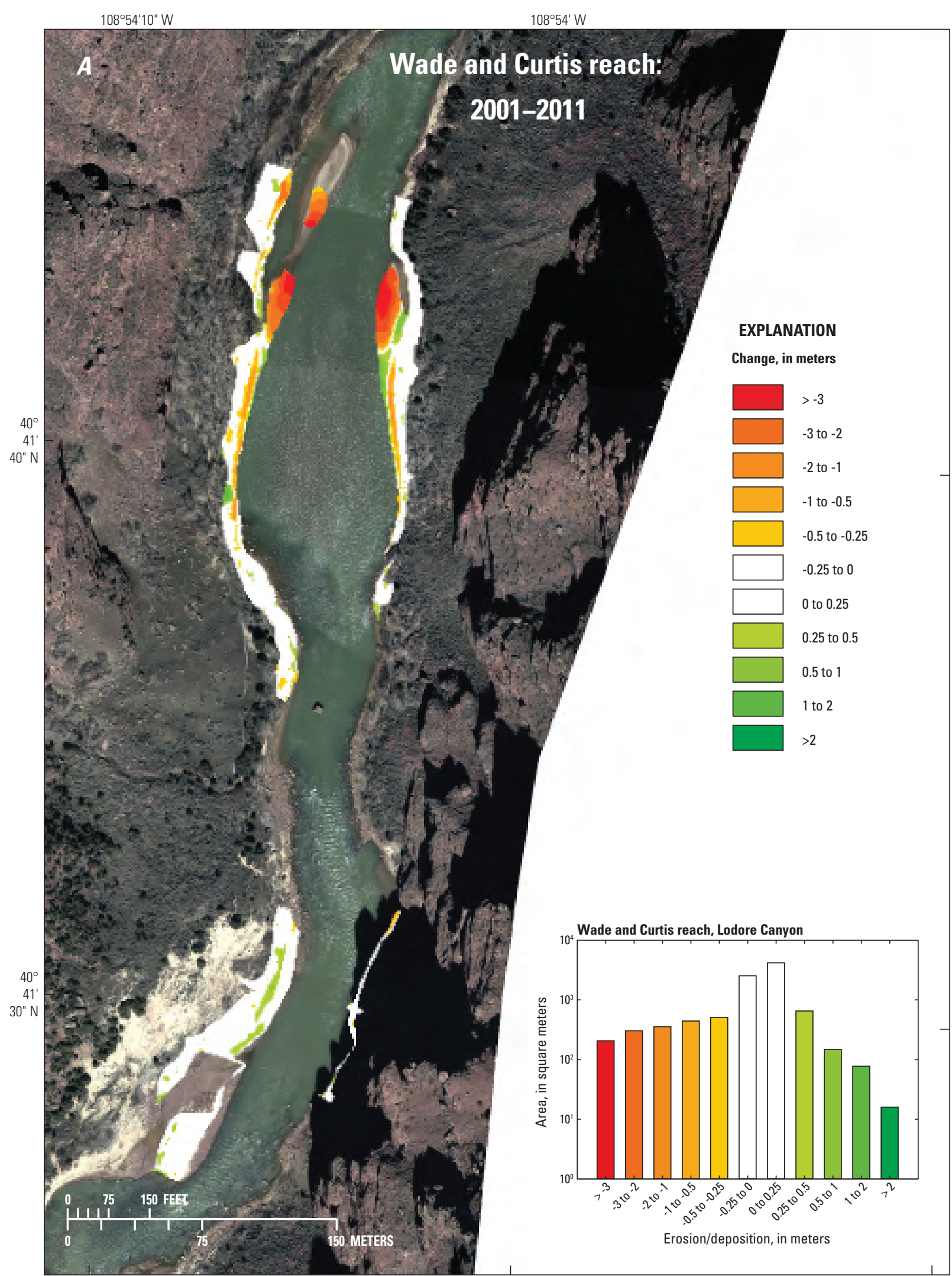

State Plane, Colorado north zone 0501 NAD 1983 (NSRS 2007). Orthophotos acquired 2005.

Figure 13. Geomorphic change between 2001 and 2011 surveys for the $(A)$ Wade and Curtis reach and $(B)$ Winnies reach on the Green River in Canyon of Lodore, Dinosaur National Monument, Colorado and Utah. Inset shows a histogram of area change for different erosion/deposition depths. The significance threshold for change of approximately \pm 0.25 meters is shown in white on the map. Streamflow is from north to south. $>$, greater than. 


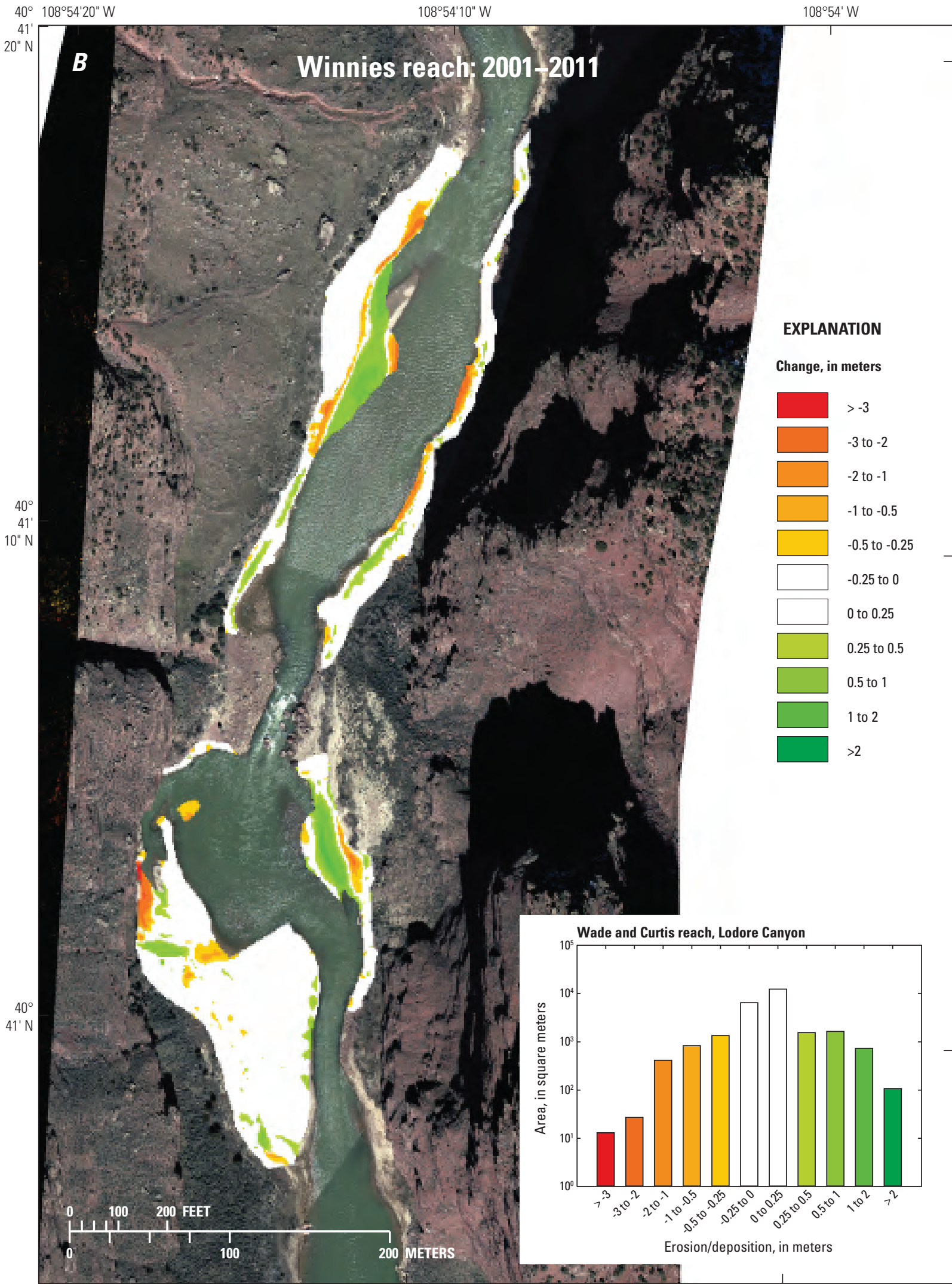

State Plane, Colorado north zone 0501 NAD 1983 (NSRS 2007) Orthophotos acquired 2005.

Figure 13. Geomorphic change between 2001 and 2011 surveys for the $(A)$ Wade and Curtis reach and $(B)$ Winnies reach on the Green River in Canyon of Lodore, Dinosaur National Monument, Colorado and Utah. Inset shows a histogram of area change for different erosion/deposition depths. The significance threshold for change of approximately \pm 0.25 meters is shown in white on the map. Streamflow is from north to south. $>$, greater than. - Continued 


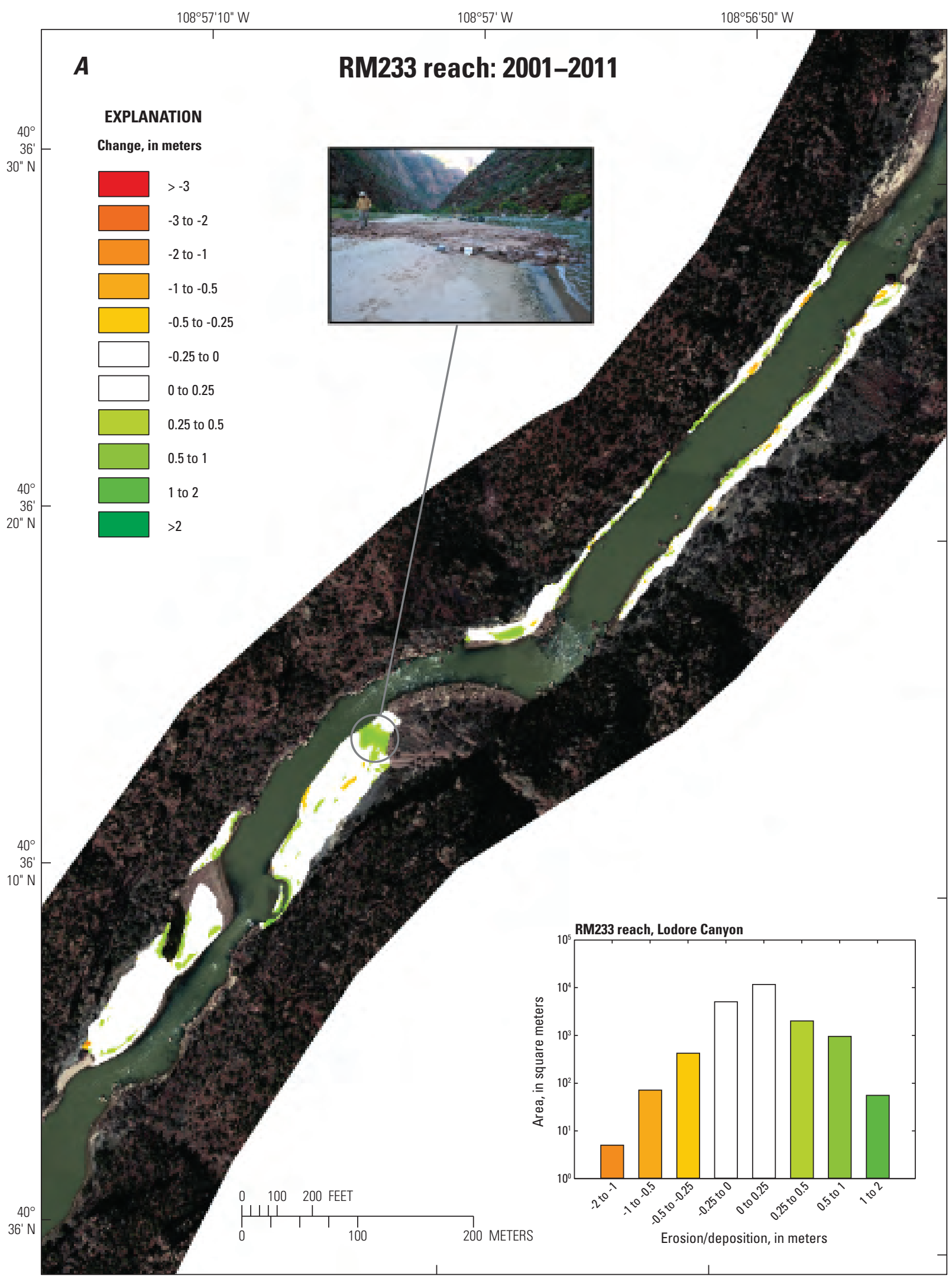

State Plane, Colorado north zone 0501 NAD 1983 (NSRS 2007).

Orthophotos acquired 2005.

Figure 14. Geomorphic change between 2001 and 2011 surveys for the $(A)$ RM233 reach and the $(B)$ Triplet reach on the Green River in Canyon of Lodore, Dinosaur National Monument, Colorado and Utah. Inset shows a histogram of area change for different erosion/deposition depths. The significance threshold for change of approximately \pm 0.25 meters is shown in white on the map. $A$, shows fresh debris flow on sandbar; $B$, shows fresh sand deposits along the channel margin on river right. Streamflow is from northeast to southwest. >, greater than. 


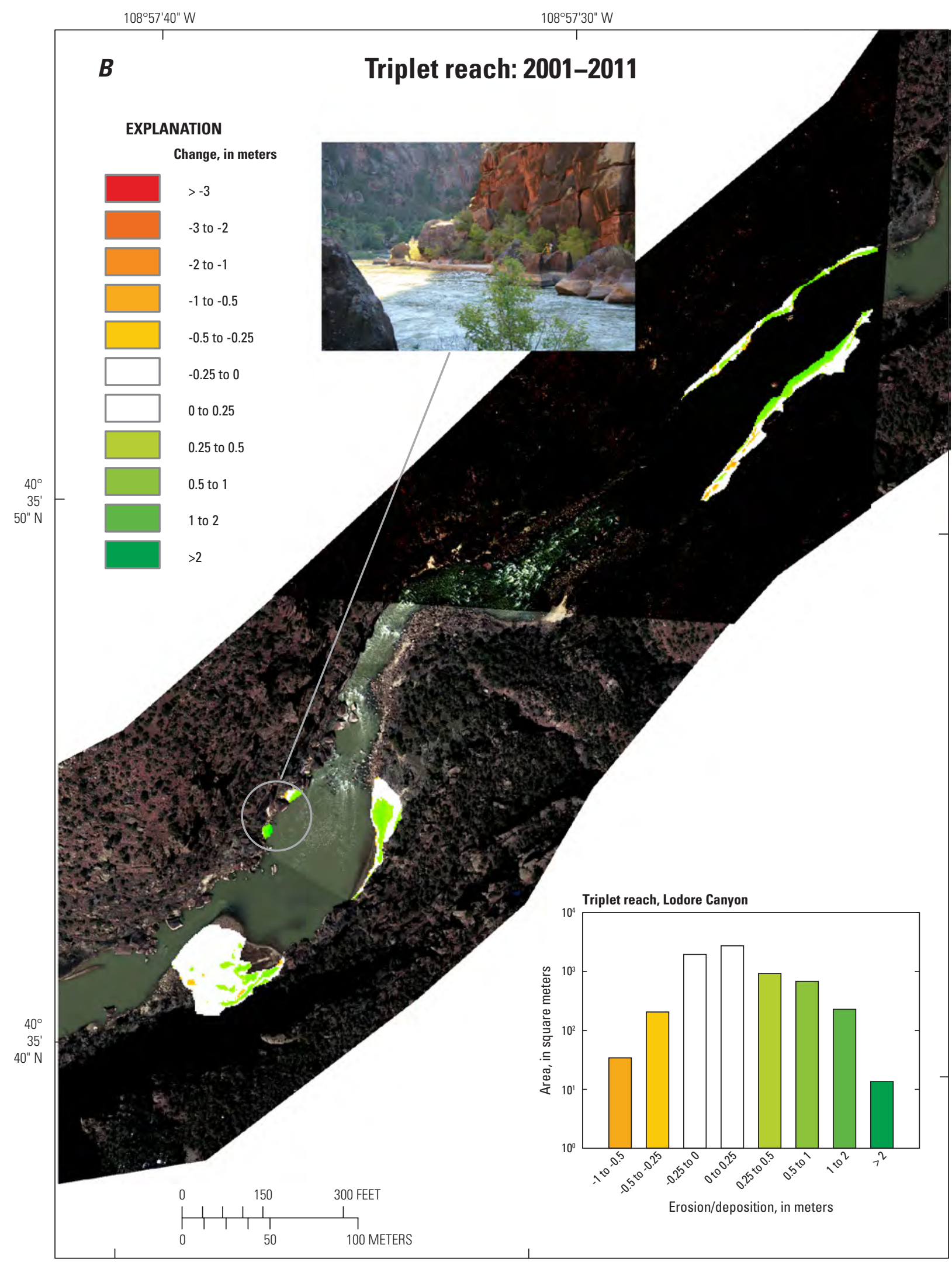

State Plane, Colorado north zone 0501 NAD 1983 (NSRS 2007)

Orthophotos acquired 2005

Figure 14. Geomorphic change between 2001 and 2011 surveys for the $(A)$ RM233 reach and the $(B)$ Triplet reach on the Green River in Canyon of Lodore, Dinosaur National Monument, Colorado and Utah. Inset shows a histogram of area change for different erosion/ deposition depths. The significance threshold for change of approximately \pm 0.25 meters is shown in white on the map. $A$, shows fresh debris flow on sandbar; $B$, shows fresh sand deposits along the channel margin on river right. Streamflow is from northeast to southwest. >, greater than. - Continued 
separate from changes that may be expected due to changing flow levels, which also affect the suspended sand grain size. Fine to medium sand $(0.22-0.5 \mathrm{~mm}$ from image analysis; $0.13-0.28 \mathrm{~mm}$ from sieve analysis) typifies the grain size in all bars with no clear vertical sorting (appendix 2). The grain size from image analysis is generally well correlated with the grain size using traditional sieving, but roughly 50-percent coarser; this technique is particularly sensitive to detecting the size of surface grains and may give results coarser than bulk grab samples due to winnowing of fine sediments by wind or trench excavation (Rubin and others, 2007). These sand grain sizes tend to be consistent with the measured bed load at the coarse end, and with the measured suspended load at the fine end, as sampled by Martin and others (1998) in Browns Park during high flow releases in 1997. In either case, depending on the source and magnitude of sediment inputs, sand grain size is likely to vary considerably from year to year (Topping and others, 2010). Continuous suspended sediment sampling devices currently deployed on the Green-Yampa Rivers centered on Dinosaur National Monument will allow us to match the suspended sediment and alluvial bar characteristics. Considering the ease of collecting hundreds or potentially thousands of samples of surface or trench grain size using the camera technology, it is worth considering a more robust sampling campaign in future studies - especially during flood events - to better document trends in temporal and spatial variability of sand grain size.

The stratigraphy of the 2011 flood deposits was described in one to three trenches in each of the study reaches (fig. 15). In general, ripple-drift cross stratification composed of climbing ripples of fine to medium sand and reflecting sediment transport directions characteristic of recirculating flow were interbedded with cyclic foresets composed of medium sand that are typical of dune migration in deeper or more energetic flow (fig. 16). The photo inset in figure 16 shows a sequence in which cyclic foresets overlay climbing ripples, perhaps reflecting deposition as depth or velocity increased during the flood. Despite the general similarities between sites, there is not a clear pattern in stratigraphy or flood-deposit grain size in the study area (appendix 2). Instead, vertical variation in grain size appears random, with an average particle-size distribution median diameter $\left(\mathrm{D}_{50}\right)$ of $0.33 \mathrm{~mm}$ from the image analysis and $0.20 \mathrm{~mm}$ from the sieve analysis. Because there were two flood peaks separated by nearly a month of lower flows (fig. 2B), each sandbar may not represent continuous bar growth. Nevertheless, the stratigraphy clearly shows aggradation of sandbars from the 2011 flood ranging from $0.2-1 \mathrm{~m}$ at the sampling locations.

\section{Tracer Rock Movement}

We summarize the results from tracer rock recovery in 2011 in table 4, with locations and histograms of the degree of movement shown in figure 15. In the Wade and Curtis reach, high flows covered the study gravel bar on river right (fig. 15A), resulting in moderate to major movement of four gravel patches, and burial or possible removal of four other patches; two locations experienced minor entrainment. At sites where gravel motion was significant, tamarisk were damaged but not removed. Rocks as large as $180 \mathrm{~mm}$ were moved in several locations, but in general the coarsest clasts (greater than $128 \mathrm{~mm}$ ) were stable. Additionally, significant amounts of fresh sand accreted on parts of the gravel bar. At the Winnies gravel bar, most of the painted rocks were relocated, although one location was deeply scoured and not found. Four out of the eight patches at Winnies experienced minor movement, although in some cases sand was scoured from the bed. The other three sites showed moderate to major movement. Even in the cases of major movement, approximately 50 percent of the clasts remained in place, even though coarse grains as large as $128 \mathrm{~mm}$ moved.

For the RM233 gravel bar, painted rocks in general showed moderate to major movement, with only two locations showing minor movement (fig. 15B). Three sites were never found, but individual clasts from these patches were found as much as $15-25 \mathrm{~m}$ downstream, suggesting other clasts were transported further. Significant motion of clasts ranging from $45-90 \mathrm{~mm}$ was evident, as well as movement of one 256-mm particle. Very minor movement was found at all locations at the Triplet gravel bar, with all recovered patches showing 90-95 percent of clasts in place (fig. 15B, table 4). Most motion occurred in the $22-64 \mathrm{~mm}$ range, with some lesser movement of bigger particles as large as $128 \mathrm{~mm}$, although this activity was very limited. Painted rock recovery was very poor at Limestone Island and may indicate significant movement or simply burial by accreted sand (table 4). Zero to minor movement and some sand deflation was evident at the downstream end of the island, which was largely too high to be inundated. The upstream part of the gravel bar was covered in new sand, suggesting that this part of the bar was submerged, and some gravel transport would have been possible in the missing patches. Overall, the combined data from the gravel bars suggest significant movement of coarse particles in many locations, but not wholesale gravel-bar reworking, with major movement isolated to individual gravel bars or localized areas of intense flow. Nevertheless, this coarse particle mobility represents the most significant observed since monitoring began in the early 2000s.

\section{Geomorphic Effects of the 2011 Flood in Lodore Canyon}

Controlled flood releases from Flaming Gorge Dam in 2011 were the third highest peak of the Green River in Lodore Canyon since dam closure. In this section, we describe the geomorphic response to this event using the observations from the September 2011 field campaign, in relation to data from previous cross-sectional surveys (figs. 17-20). We also use the 2001-2011 DoDs as a proxy for changes that occurred in 2011. Although more than a decade of intervening flows occurred, Alexander (2007) reported that significant morphologic change at the majority of these sites only occurs during 
large floods, most notably the 1999 flood (fig. 2A). We thus use the cross-section change record as our primary data source to interpret the effects of the 2011 flood and supplement this with interpretation of the 2011 DEMs and 2001-2011 DoDs.

\section{DEM and Cross-Section Interpretation}

In the Wade and Curtis reach, deep erosion in the pool at the upstream end of the reach was clearly evident, with as much as $5 \mathrm{~m}$ of degradation having occurred since the 2006 survey (figs. 9 and 17). Evidence for this degradation is also shown in the 2001-2011 DEM difference maps (fig. 13A), which depict the erosion of eddy sandbars in the upstream part of the reach. However, the data also show that these sandbars, which formed during relatively modest flows, likely shifted downstream in the high-flow event, as sandbars near both the left and right banks are shown in both the DEM (fig. 9) and in cross section (XS) 4 (fig. 17). Excavations into the 2011 flood deposit in each of these sandbars indicate that the minimum deposit thicknesses were $0.5-0.8 \mathrm{~m}$ (figs. 15 and16). The lower part of this reach was not surveyed in as great of detail; however, the gravel bar on river right was significantly entrained, and there was some damage to tamarisk.

There was also deep erosion (figs. 10 and 18) in the upstream part of the Winnies reach along river left, with corresponding deposition of a large eddy sandbar along river right (fig. 10; fig. 18, cross sections 2 and 4). At least $0.6 \mathrm{~m}$ of deposition occurred on this sandbar (fig. 16, LC4), and the DEM differencing showed as much as $2 \mathrm{~m}$ of deposition relative to 2001 on this bar (fig. 13B). Downstream from Winnies rapid, the channel has been deeply eroded, and the thalweg follows a tortuous path around a large gravel bar on river right (fig. 10). Although this bar has aggraded significantly in the past, the 2011 flood caused minor bed degradation relative to 2006 (fig. 18, cross section 8). A small sandbar with thickness greater than $1 \mathrm{~m}$ (fig. 13B; fig. 16, LC5) was deposited on river left in the eddy downstream from Winnies rapid. The gravel bar showed signs of significant movement in some locations, particularly at the upstream end (table 4). For both the Wade and Curtis and Winnies reaches, channel change was greatest in the upstream pools, with little change at other cross sections, especially near stable features such as debris fans or gravel bars (figs. 17-18). At several of the Wade and Curtis cross sections, the channel is now eroded to its maximum observed depth. For the Winnies reach, the time series dates back further, and there are some cross sections that look quite similar to those observed following the 1999 flood event (fig. 18).

The upstream part of the RM233 reach (figs. 11 and 19) has been the most stable of all of the surveyed reaches and has changed little over time, with minor sand deposition on small eddy sandbars on each side of the channel (fig. 14A; fig. 16, LC6 and LC7). As discussed above, this part of the reach does not have a deep pool nor channel expansions. The downstream part of this reach also shows little topographic change since 2001, with the exception of a recent debris flow covering a part of the eddy sandbar adjoining the primary debris fan (fig. 14A). The channel adjacent to this large eddy bar is deep relative to the rest of the reach (fig. 11) but has not changed markedly over time (fig. 19, cross section 7). Downstream from the sandbar, the channel turns around a large gravel bar, where there has been moderate gravel entrainment (fig. 15B) but little topographic change (fig. 14A). The Triplet reach showed a response that was similar to the upstream reaches, with erosion in the pool at the upstream end of the reach, deposition of an associated eddy sandbar on river left, and grading to a more uniform channel in the backwater of the debris fan creating Triplet rapid (fig. 12; fig. 20, cross sections 2 and 4). Downstream from the debris fan, deposition occurred on the eddy sandbar on river left (fig. 16, LC9), but there was little evidence for motion on the downstream gravel expansion bar (fig. 15B; table 4). Most of the erosion in the reach likely resulted from scour during the 2011 flood, and produced the greatest observed depths in this reach (fig. 20), although data for this reach did not include measurements after the 1999 flood. The cross sections also show that changes in channel morphology were greatest upstream from the debris fan, consistent with observations in the Wade and Curtis and Winnies study reaches.

\section{Time-Series of Bed and Sandbar Elevation}

Changes in mean bed and sandbar elevation are shown for individual reaches in figure 21 and averaged over the entire study area in figure 22; each figure has three panels showing the flood, fluctuating flow, and channel bed zones as shown schematically in figure 6 and delineated in the cross-section time series shown in figures 17-20. In each figure, we plot changes in bed elevation at the same scale for the different zones, and we include the mean daily flow hydrograph for the period of observation for comparison. Elevation changes in the flood zone have been modest during the study period, although some minor (approximately $100 \mathrm{~mm}$ ) aggradation did occur in both 1999 and 2011. The 1997 flood did not show this signal, but only RM233 was monitored during this event, and this reach has been relatively insensitive to change compared to the other monitoring sites. Data from 1994 at Wade and Curtis is based on a single cross section, and may not be representative of the longer reach. Changes in sandbar elevation for the fluctuating flow zone are more variable than in the flood zone. For example, sandbars in the Winnies reach aggraded by more than $0.5 \mathrm{~m}$ during the 1999 event (fig. 21). Subsequently, the sandbars eroded in the early 2000s, then were partially rebuilt during bypass floods in 2005, 2006, and 2011. The 2011 flood increased sandbar elevations in the fluctuating flow zone by hundreds of millimeters in most reaches, although data from Winnies reach suggest the 1999 floods were more effective. These changes in sandbar elevation are subtle overall, and this is partially due to the relatively narrow elevation range of the flood (approximately $0.1-1 \mathrm{~m}$ ) and fluctuating flow (approximately 1-2 m) zones as shown in figure 6 . As shown in the DEMs of difference (figs. 13 and 14) and cross-section time series (figs. 17-20), localized erosion and deposition has been commonly more than $2 \mathrm{~m}$. 


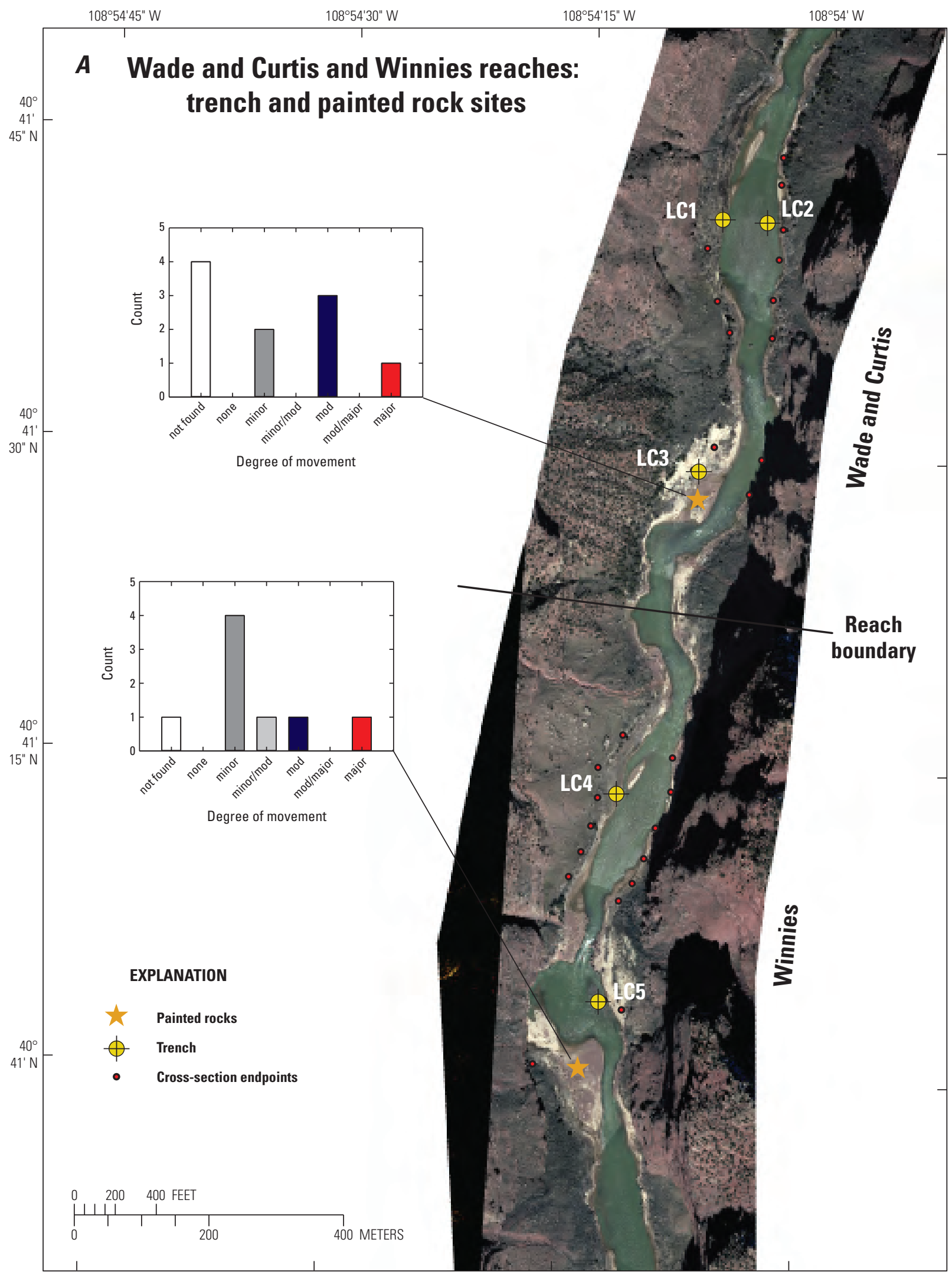

State Plane, Colorado north zone 0501 NAD 1983 (NSRS 2007) Orthophotos acquired 2005.

Figure 15. Locations of trenches and painted tracer rock sites for $(A)$ the Wade and Curtis and Winnies reaches and for $(B)$ the RM233 and Triplet reaches on the Green River in Canyon of Lodore, Dinosaur National Monument, Colorado and Utah. Cross-section end points for reference. Inset bar graphs show degree of painted rock movement as described in table 4. Streamflow is from north to south in $A$ and northeast to southwest in $B$. mod, moderate. 


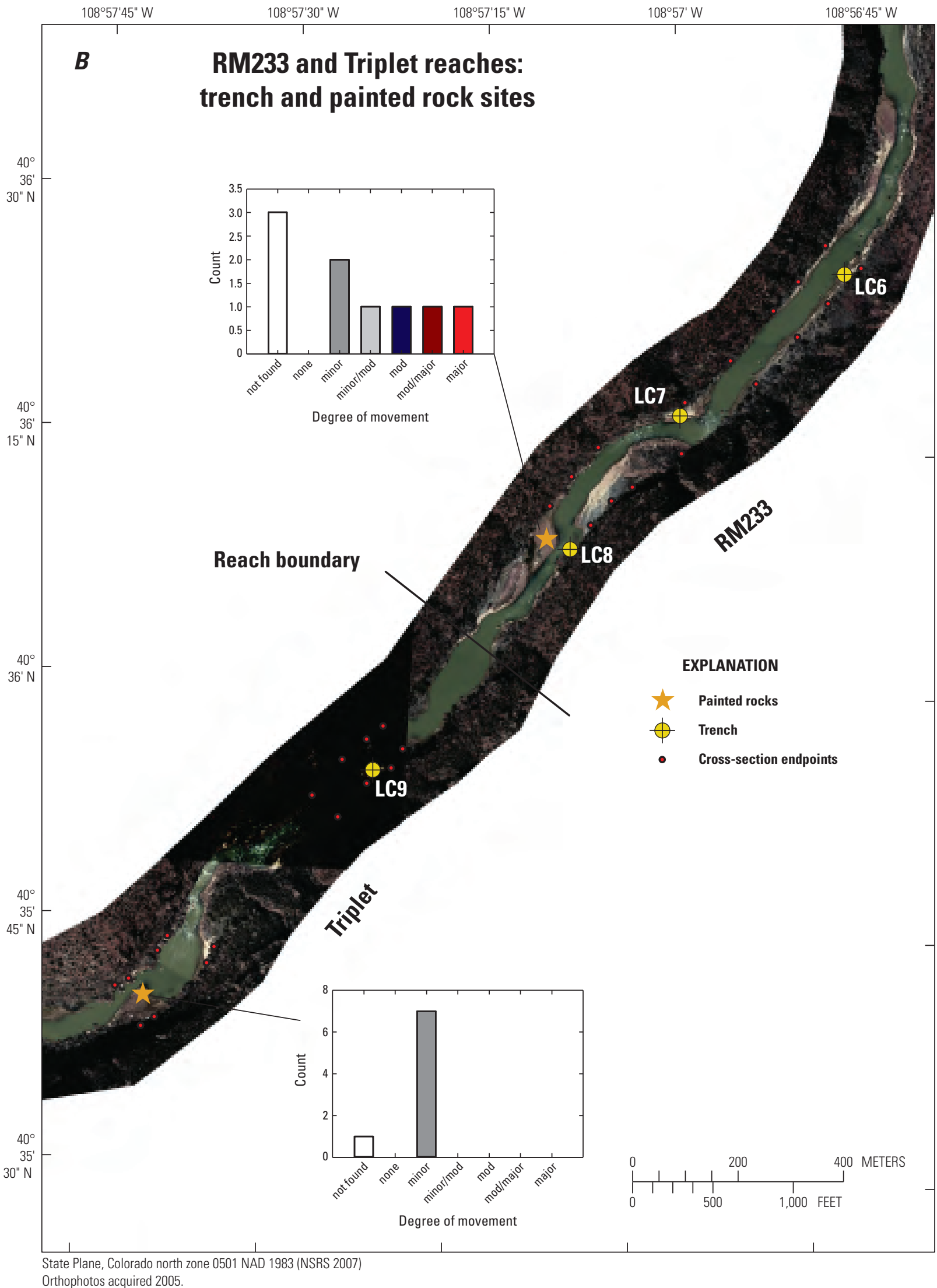

Figure 15. Locations of trenches and painted tracer rock sites for $(A)$ the Wade and Curtis and Winnies reaches and for $(B)$ the RM233 and Triplet reaches on the Green River in Canyon of Lodore, Dinosaur National Monument, Colorado and Utah. Cross-section end points for reference. Inset bar graphs show degree of painted rock movement as described in table 4. Streamflow is from north to south in $A$ and northeast to southwest in $B$. mod, moderate. - Continued 

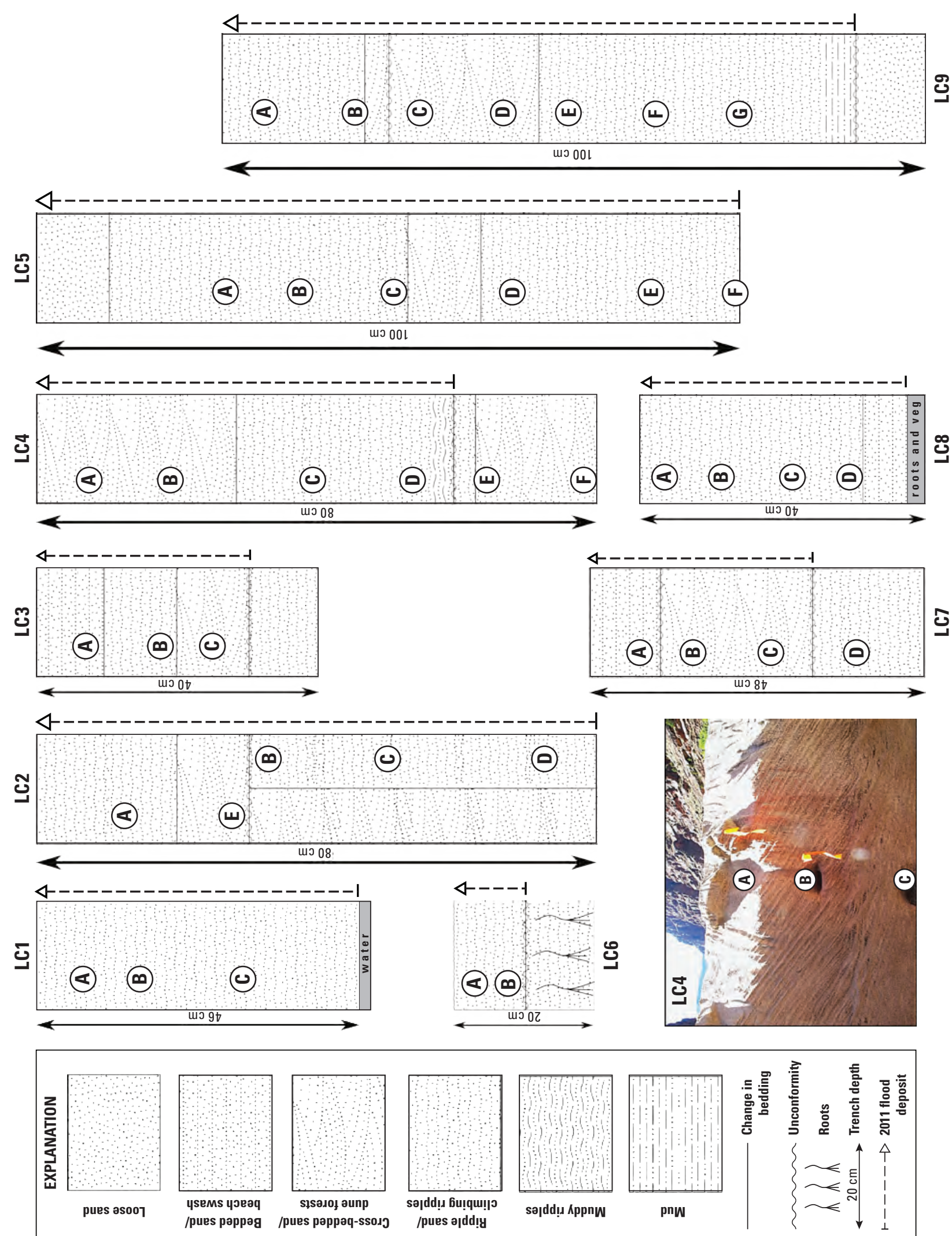

奇 올

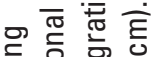

을

定空

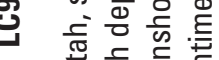

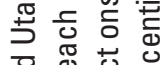

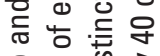

응

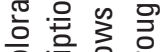

응

式糙 웅

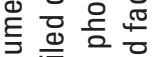

言 要

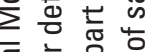

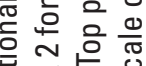

동

ट

要

क人

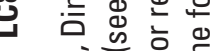

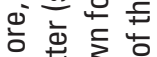

要

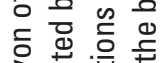

월을

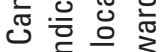

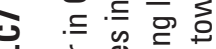

离

政

के

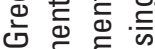

o

co

층

흥ㅎㅁ

잉

象 등

든 든

楁㖣

要

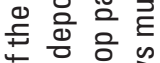

응

등은 方 음

坖云穴

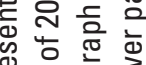

凹 는

흥동응 으

능등 엉

曾 宁

흐음

跣

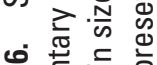

๒

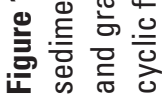




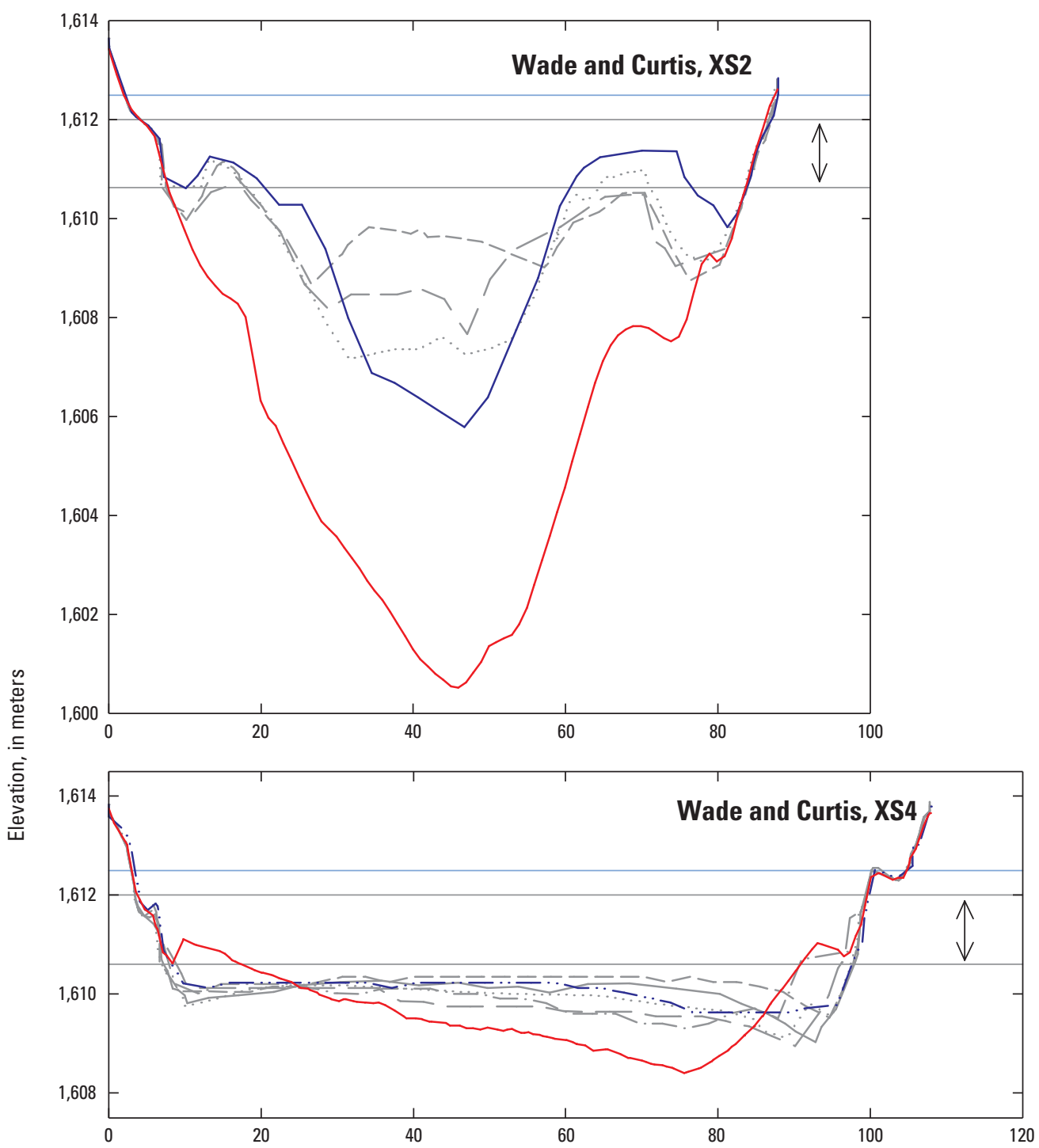

EXPLANATION
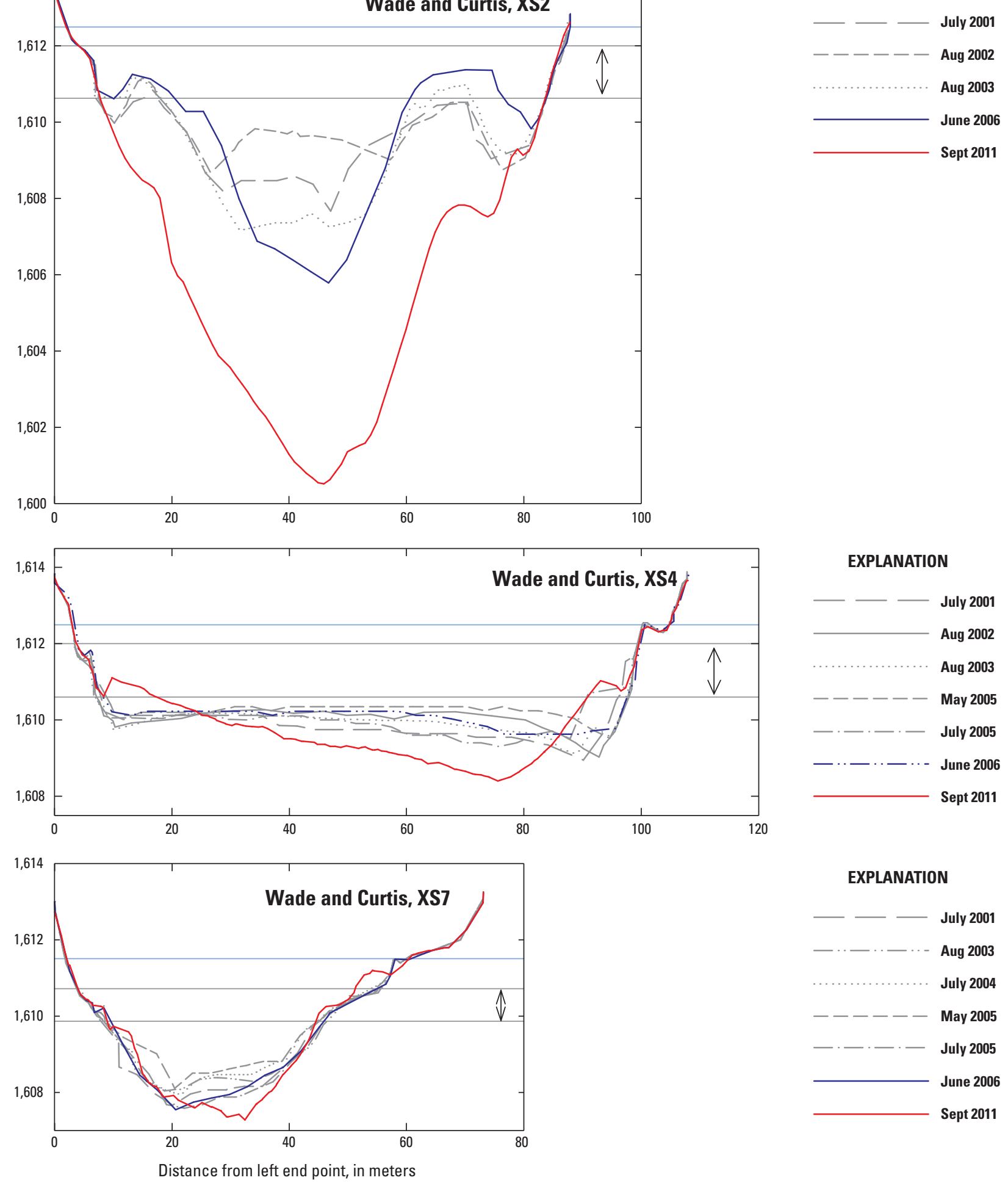

EXPLANATION

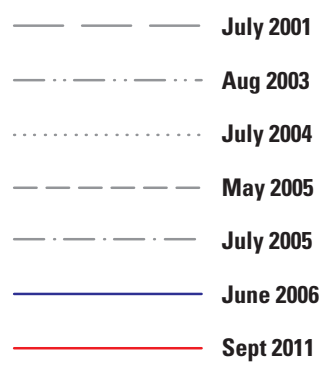

Figure 17. Channel change at select cross sections for the Wade and Curtis reach on the Green River in Canyon of Lodore, Dinosaur National Monument, Colorado and Utah. Upper light blue line indicates the 2011 flood elevation; lower gray lines delineate the fluctuating flow zone. Vertical double arrows indicate typical range in normal dam operational flows. XS, cross section. 


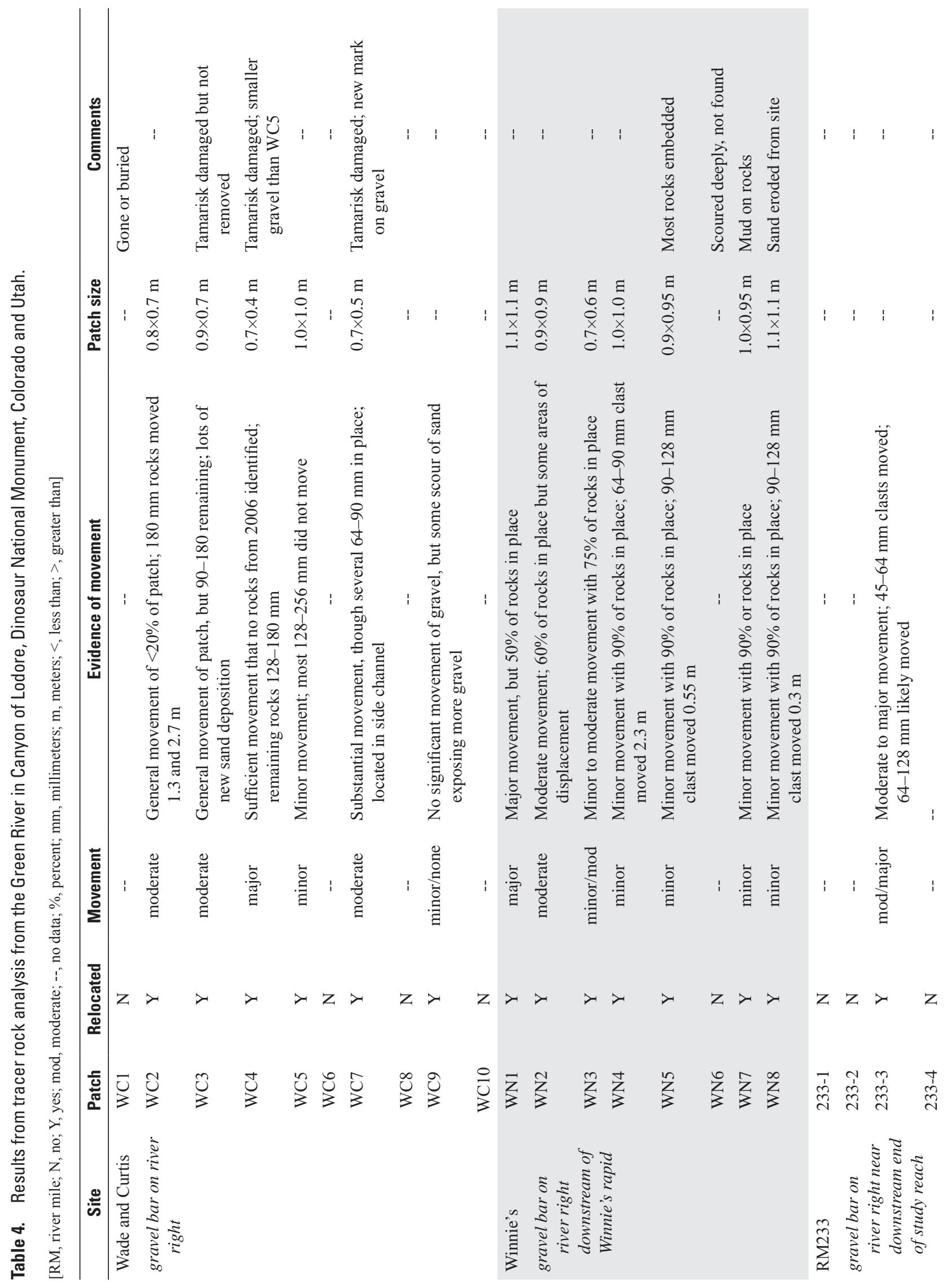




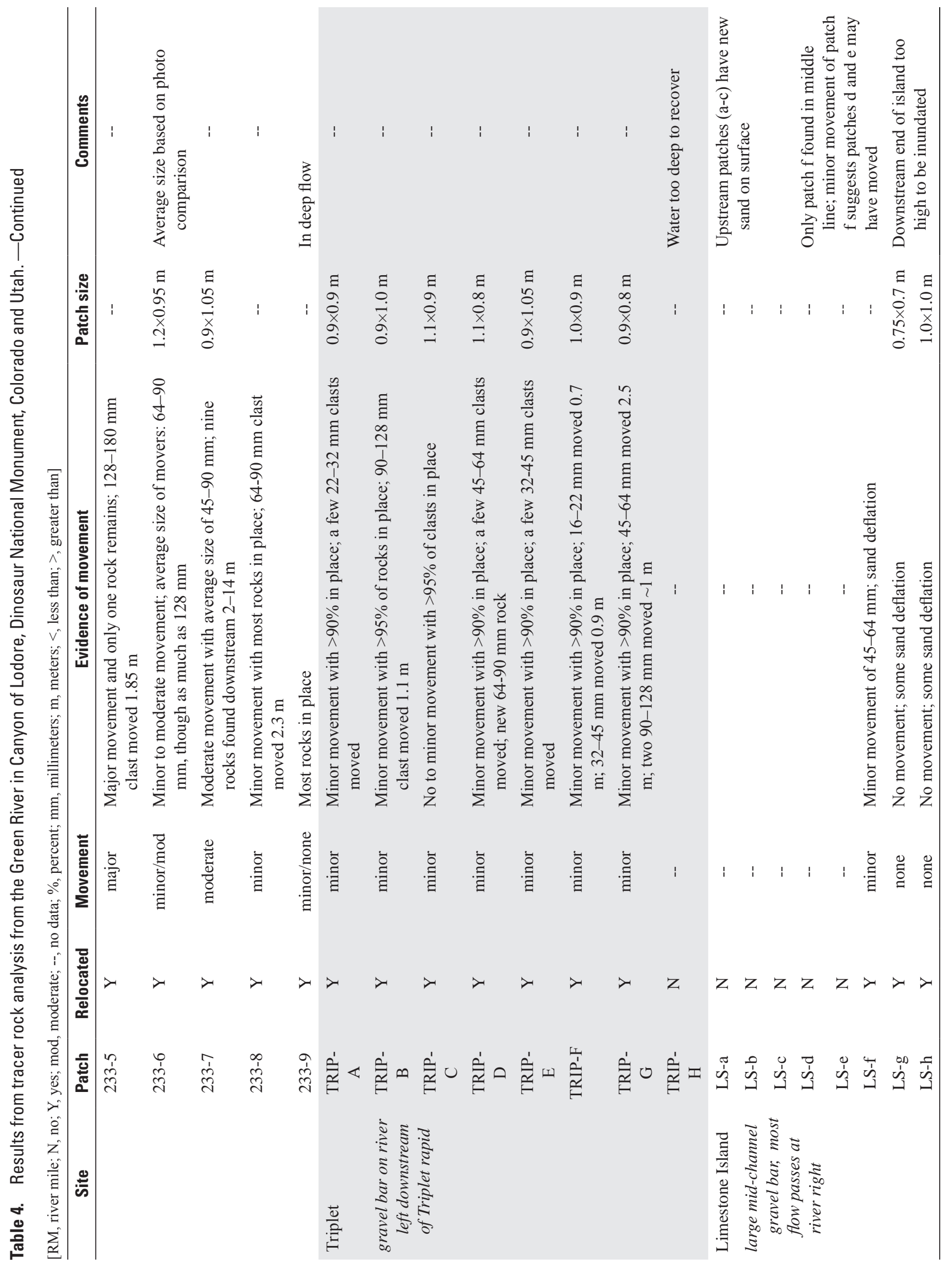




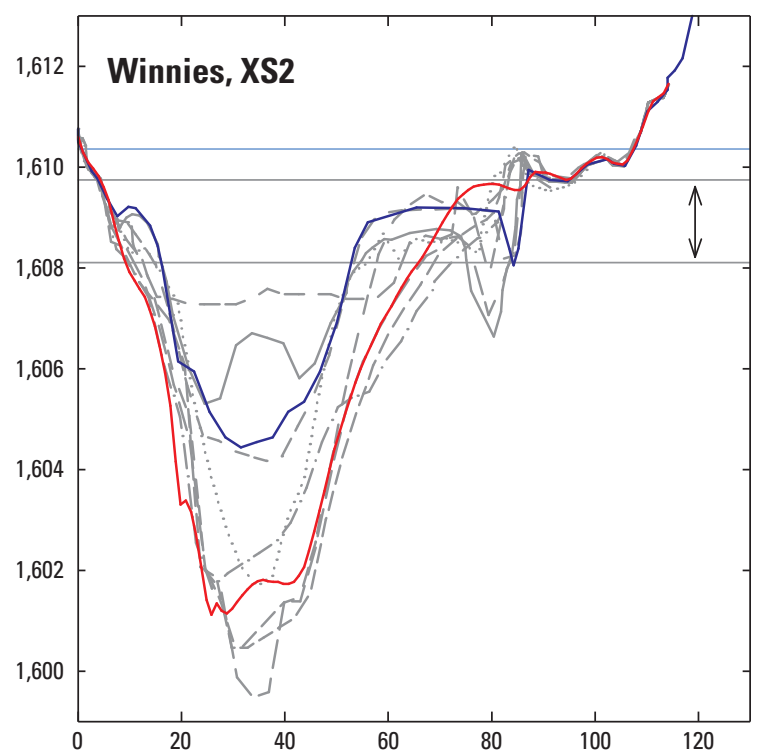

EXPLANATION
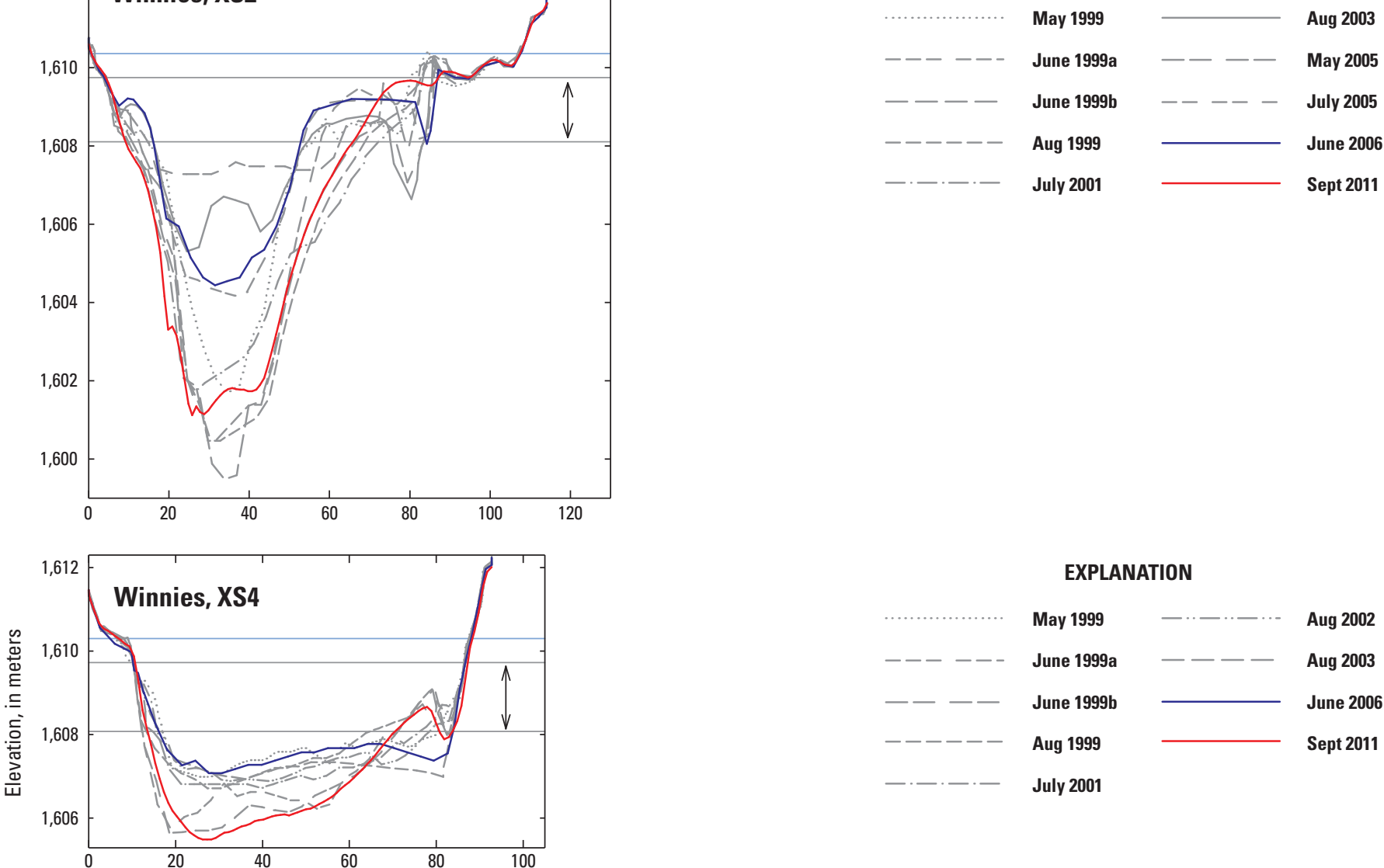

EXPLANATION

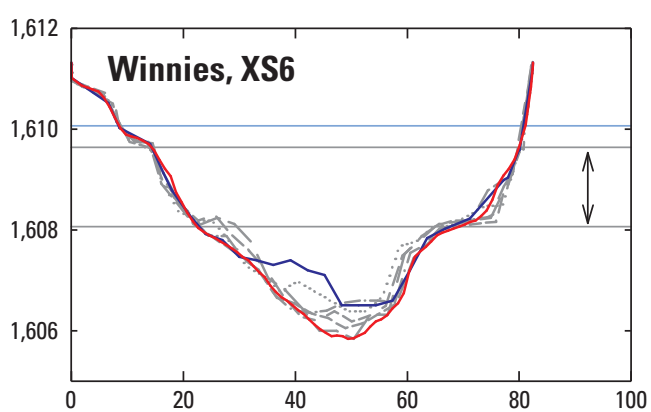

\section{EXPLANATION}
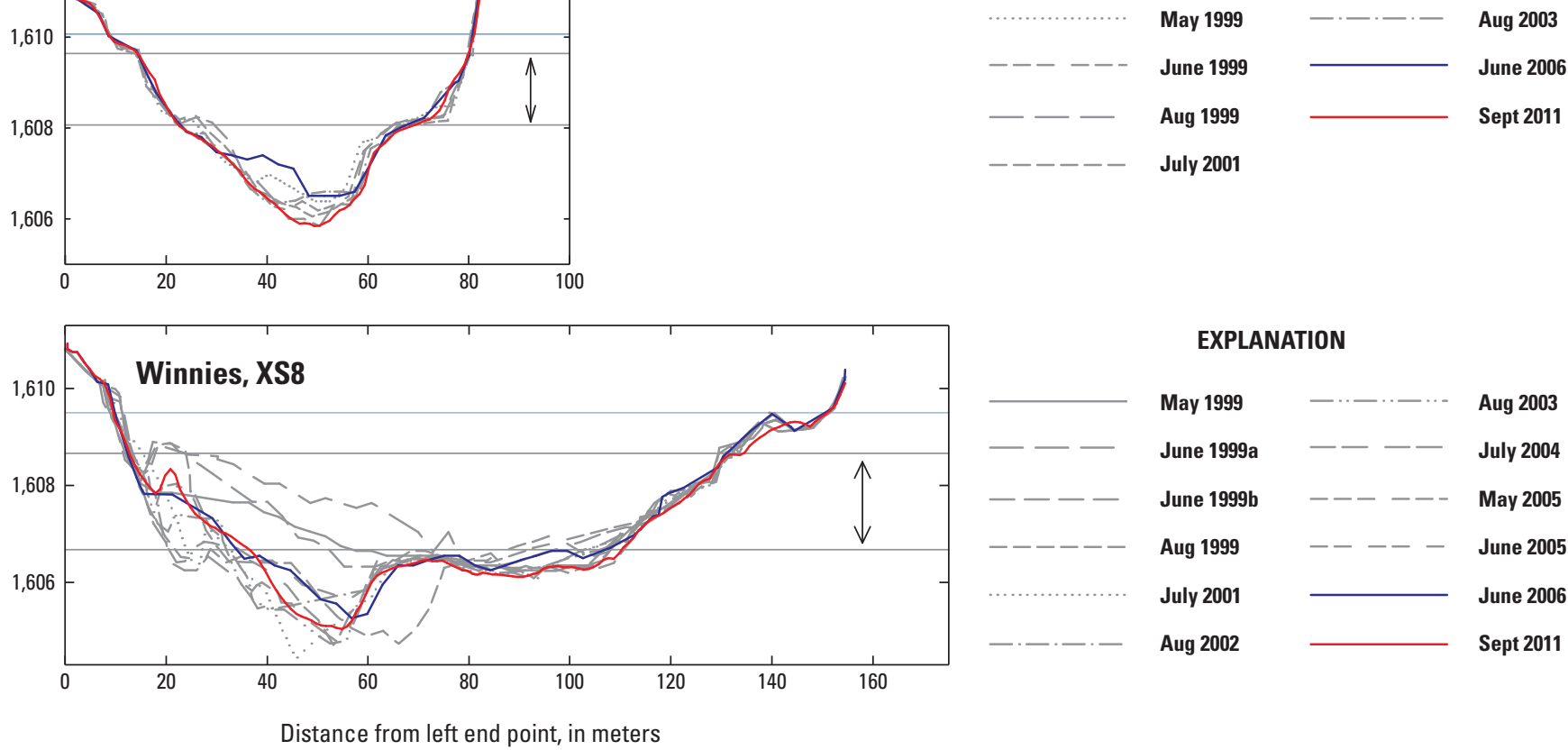

EXPLANATION

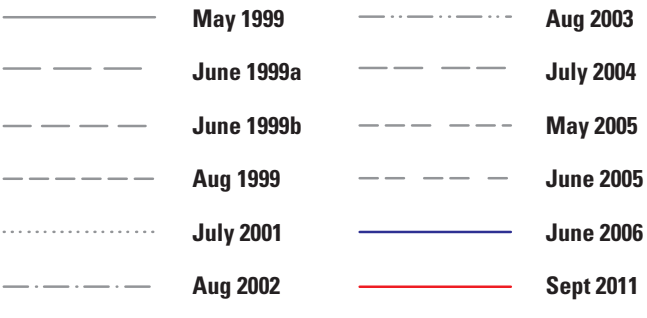

Figure 18. Channel change at select cross sections for Winnies reach on the Green River in Canyon of Lodore, Dinosaur National Monument, Colorado and Utah. Upper light blue line indicates the 2011 flood elevation; lower gray lines delineate the fluctuating flow zone. Vertical double arrows indicate typical range in normal dam operational flows. XS, cross section. 


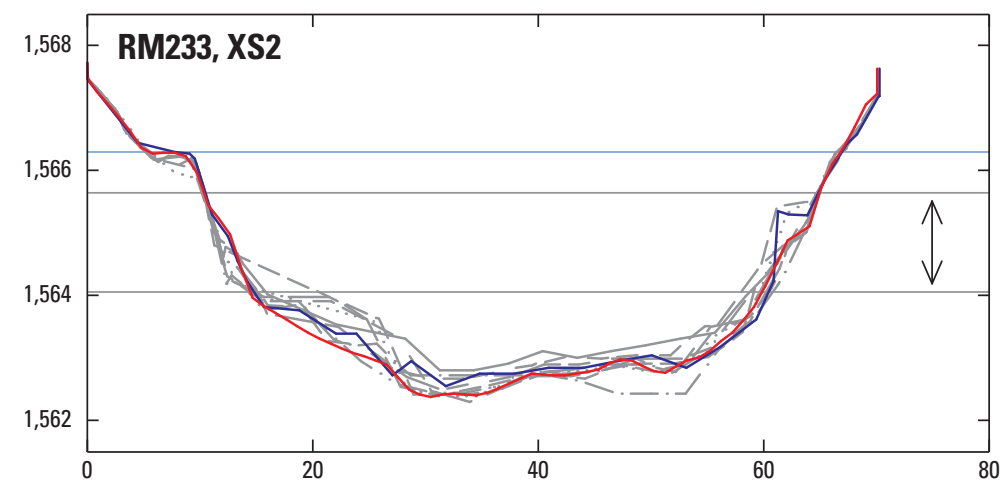

\section{EXPLANATION}
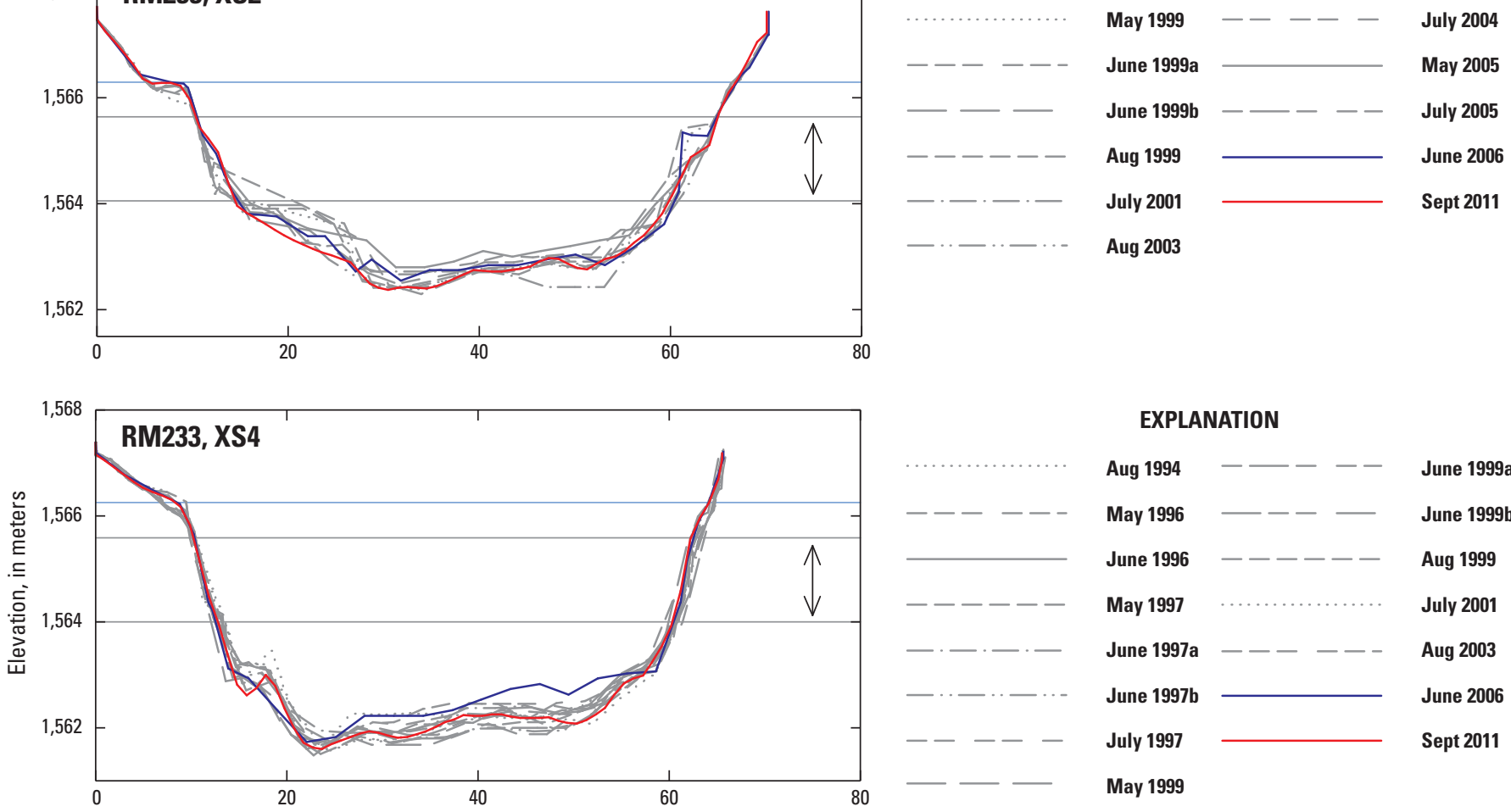

\section{EXPLANATION}
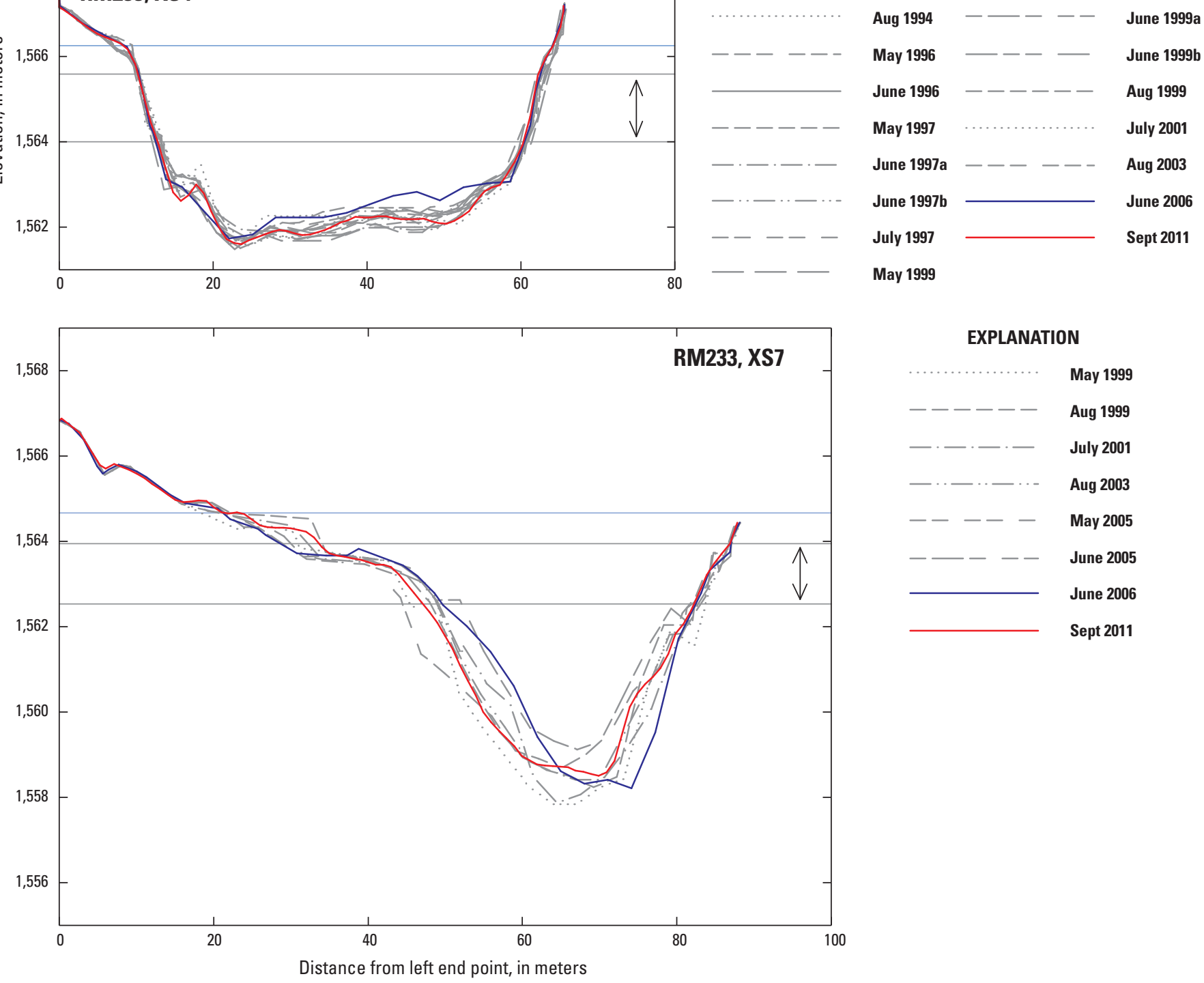

EXPLANATION

May 1999

Aug 1999

July 2001

Aug 2003

May 2005

June 2005

June 2006

Sept 2011

Figure 19. Channel change at select cross sections for the RM233 reach on the Green River in Canyon of Lodore, Dinosaur National Monument, Colorado and Utah. Upper light blue line indicates the 2011 flood elevation; lower gray lines delineate the fluctuating flow zone. Vertical double arrows indicate typical range in normal dam operational flows. XS, cross section. 


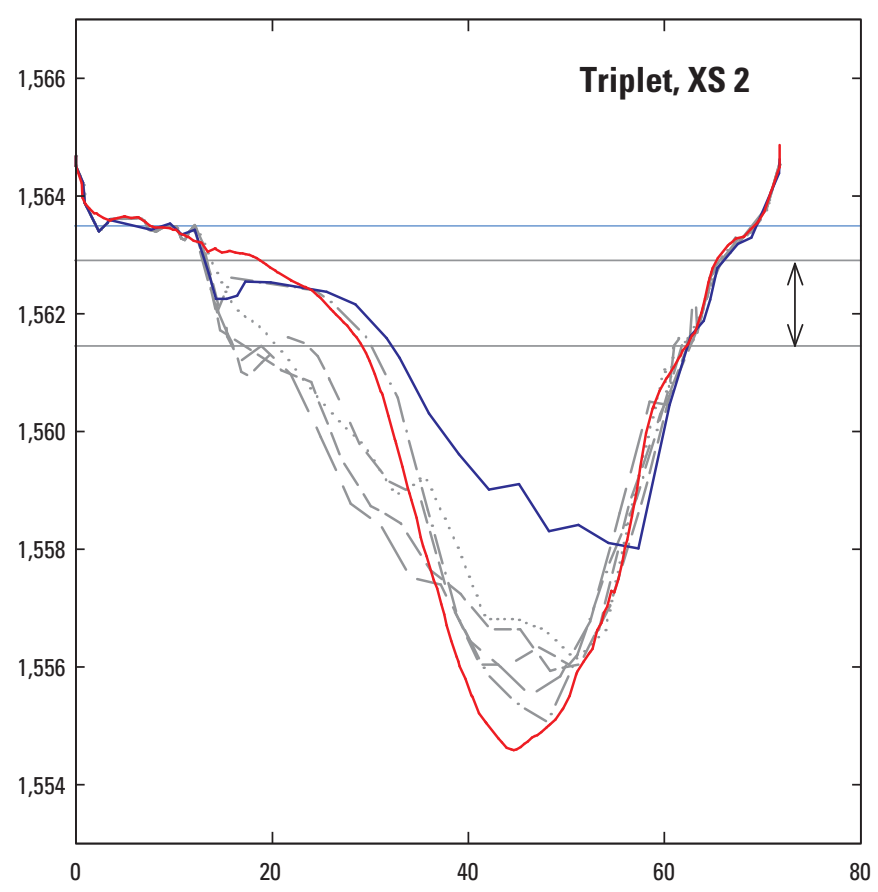

EXPLANATION
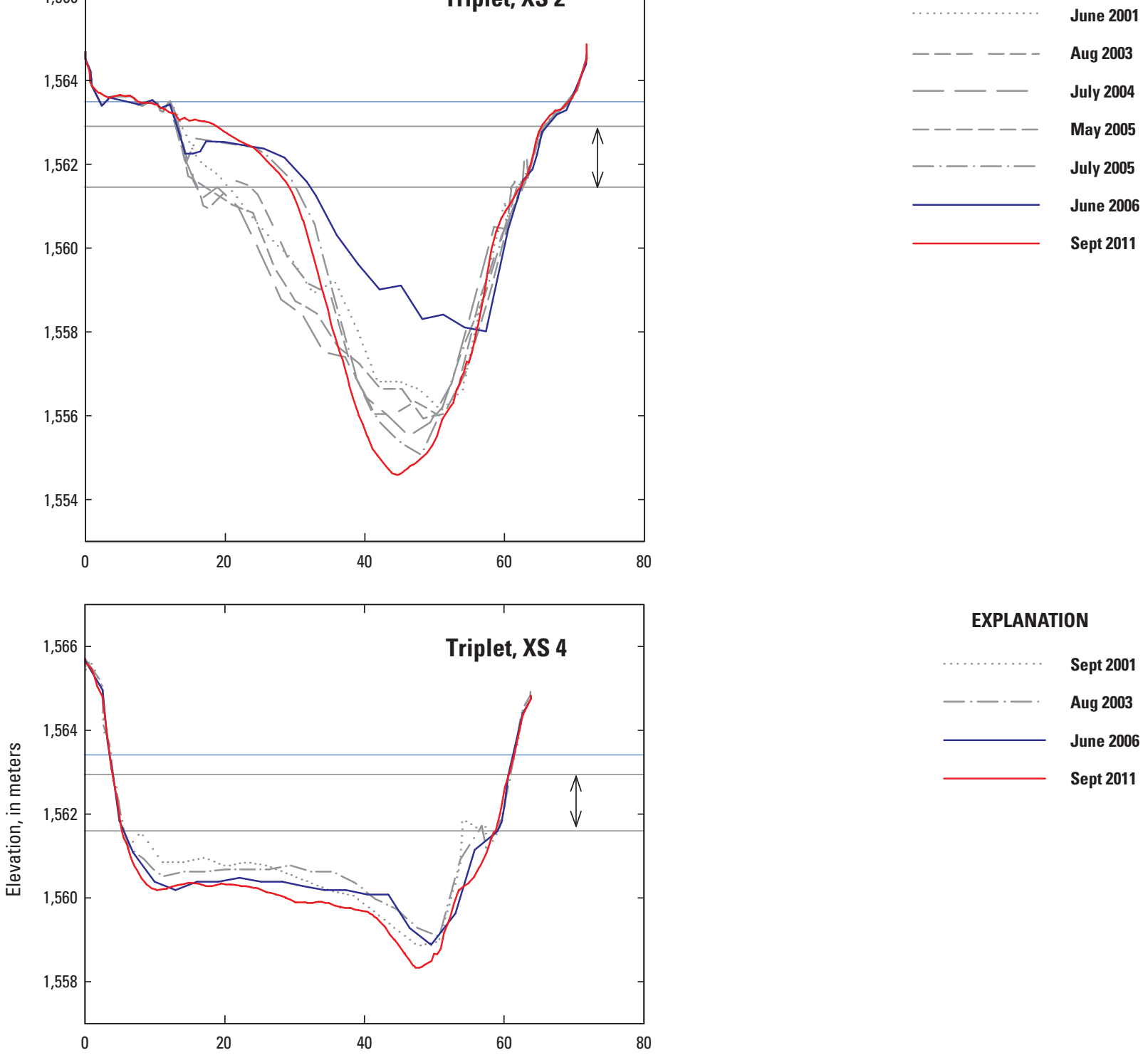

EXPLANATION

2001
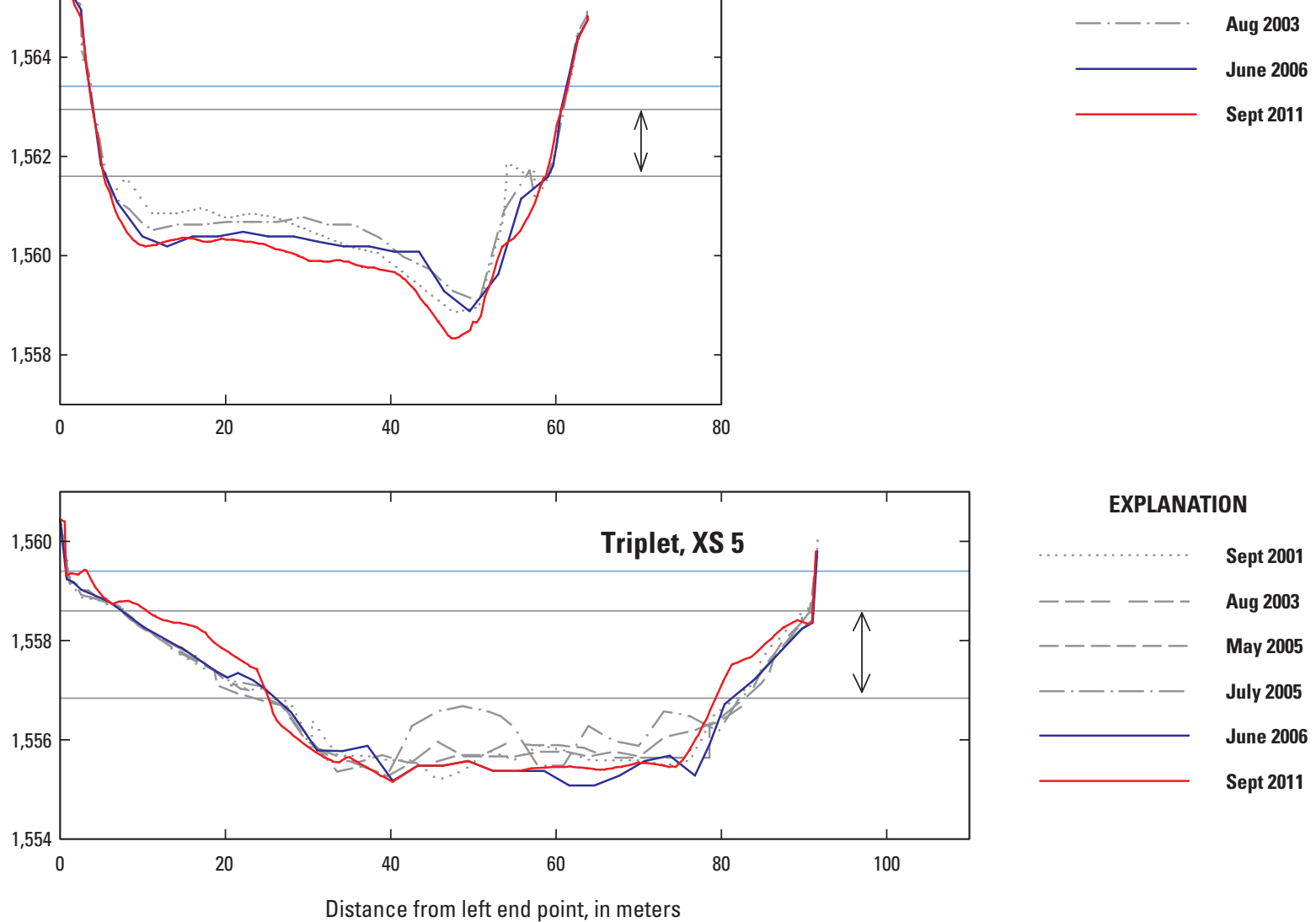

EXPLANATION

Sept 2001

Aug 2003

May 2005

July 2005

June 2006

Sept 2011

Figure 20. Channel change at select cross sections for the Triplet reach on the Green River in Canyon of Lodore, Dinosaur National Monument, Colorado and Utah. Upper light blue line indicates the 2011 flood elevation; lower gray lines delineate the fluctuating flow zone. Vertical double arrows indicate typical range in normal dam operational flows. XS, cross section. 


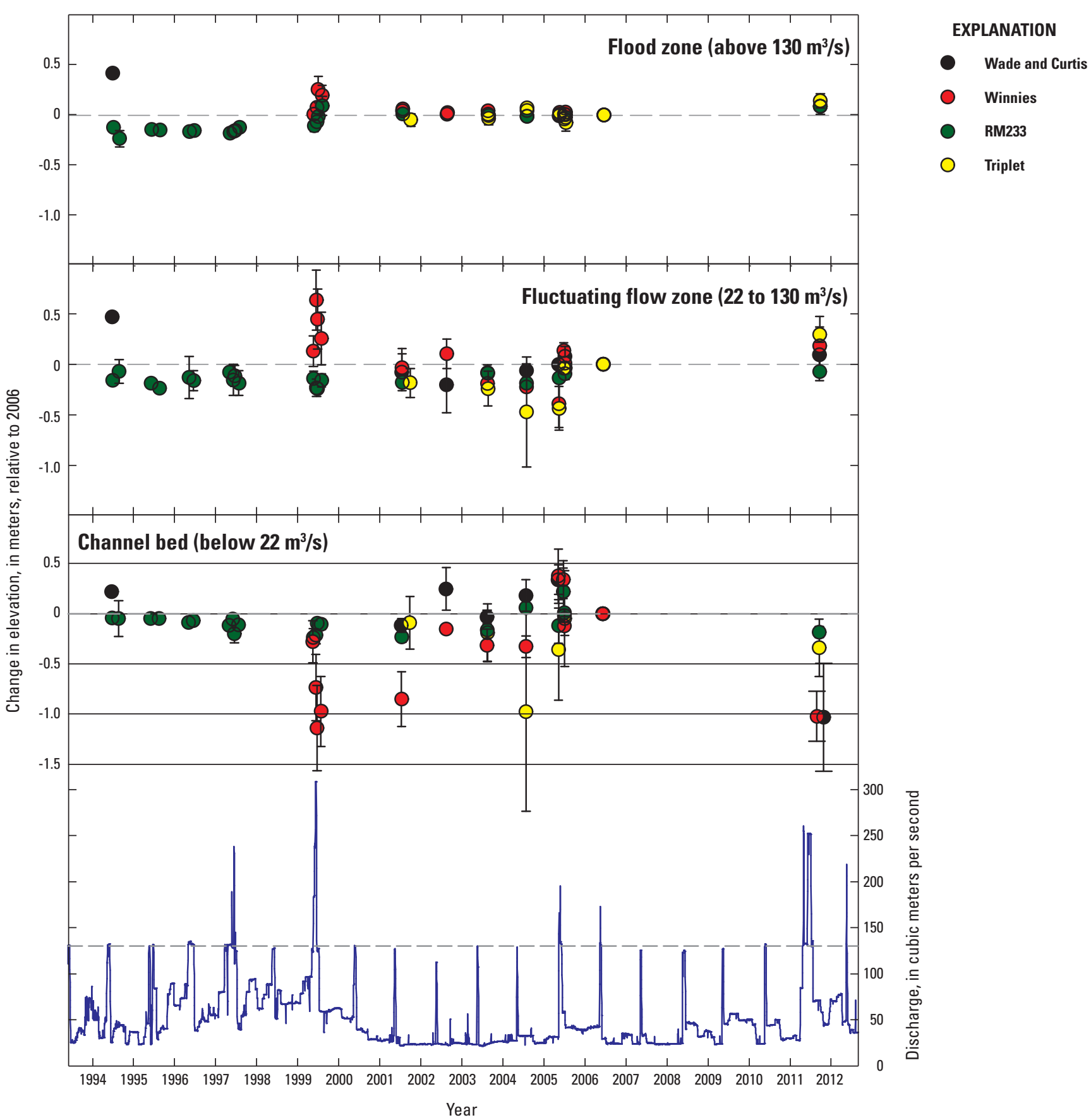

Figure 21. Change in average elevation for sandbars in the flood zone (top), fluctuating flow zone (middle), and main channel bed (bottom) of the Green River in Canyon of Lodore, Dinosaur National Monument, Colorado and Utah. Points indicate mean for all cross sections in a reach and error bars indicate the standard error of the mean. All plots are at the same scale. The mean daily hydrograph is shown for reference. $\mathrm{m}^{3} / \mathrm{s}$, cubic meters per second. 


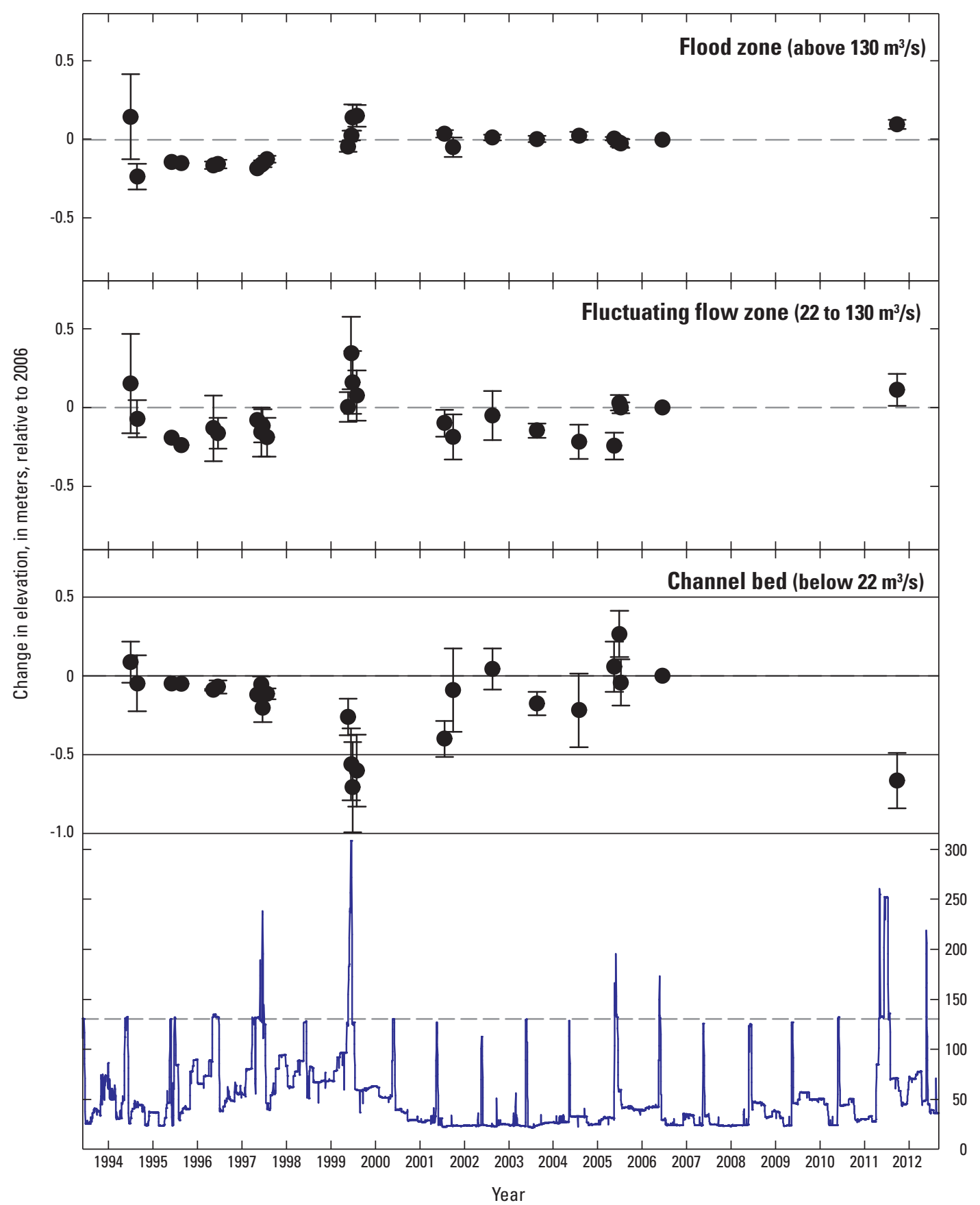

Figure 22. Change in average elevation for sandbars in the flood zone (top), fluctuating flow zone (middle), and main channel bed (bottom) of the Green River in Canyon of Lodore, Dinosaur National Monument, Colorado and Utah. Points indicate mean for all cross sections in the study area and error bars indicate the standard error of the mean. All plots are at the same scale. The mean daily hydrograph is shown for reference. $\mathrm{m}^{3} / \mathrm{s}$, cubic meters per second. 
Changes in bed elevation within the channel were both greater in magnitude and more variable than changes in the fluctuating flow and flood zones, particularly in pools. These data indicate that as much as a meter of bed scour was caused by the 1999 flood, and that the pools primarily aggraded thereafter until 2005; the 2011 flood caused significant erosion comparable to what had occurred in 1999 (figs. 21 and 22). The Wade and Curtis and Winnies reaches were the most degraded in 2011, an average of $1 \mathrm{~m}$ of bed lowering relative to 2006, and most of this erosion occurred in the upstream pools. Thus, these two sites in the upstream part of Lodore Canyon were most sensitive to flood flows. In both cases, the upstream pools in these reaches aggrade with fine sediment during typical dam operations (figs. 17 and 18). During high flows, such as in 2011, flow constrictions by debris fans just upstream from these pools concentrate flow and cause deep bed scour. Bed scour during floods appears less pronounced in downstream pools in these reaches, and may be related to coarser, less erodible substrate adjacent to gravel bars in these pools. In contrast, bed degradation in the RM233 and Triplet reaches was relatively subtle - only $0.1-0.2 \mathrm{~m}$ for an average cross section. At RM233 in particular, the upstream part of the reach is essentially flat with little bank variation and channel form has changed very little in more than a decade of monitoring.

\section{Summary of Channel Response to the 2011 Flood}

Here we summarize the channel response of the Green River in Lodore Canyon to the 2011 floods in terms of channel change and fine and coarse sediment dynamics:

- Scour of the bed occurred in the upstream pools of most reaches, but changes in bed elevation were less pronounced near stable channel controls such as debris fans and rapids and in pools adjacent to gravel bars in the downstream parts of the study reaches. The study reaches in the upstream part of Lodore Canyon (Wade and Curtis and Winnies reaches) have been more dynamic in terms of changes in fine-sediment storage than have sites in the middle part of Lodore Canyon. This may be a function of their proximity to sand sources in Browns Park (fig. 1) or to local hydraulics and geomorphic controls.

- Eddy sandbars in flow recirculation zones increased in size and height, with the biggest gains in the fluctuating flow zone, and in several cases sandbar deposition reached within 100 to $200 \mathrm{~mm}$ of the 2011 high water level in the flood zone. Nevertheless, based on time series of individual cross sections measured more frequently and for longer time periods, bed-elevation changes in the flood zone were relatively minor in comparison to changes in the fluctuating flow zone or channel bed. Sand accretion was also common on gravel bars and along channel margins based on the DoDs and stratigraphic interpretation of trenches. Despite overall sandbar growth, there was likely a net export of sand from the study reaches due to bed degradation in the main channel.
- Minor bank erosion of vegetated floodplains is evident in the DoDs between 2001 and 2011, again primarily occurring in the upstream study reaches, but these patterns are not obvious in the cross-section time series. Gravel bars showed varying degrees of mobility, but in almost all cases only partial transport of the coarse bed material occurred. Although tamarisk plants in some locations were damaged, wholesale bed motion likely necessary to fully clear these surface was not evident. Grams and Schmidt (1999) show that these bars would have likely been mobile during a pre-dam 25 -year flood (with a flow rate of approximately $530 \mathrm{~m}^{3} / \mathrm{s}$ ). The results from this study suggest that bars were near the threshold for motion during the 2011 event, and although local scour or bank erosion may erode coarse sediment or remove vegetation, full mobilization of gravel bars did not occur. Two-dimensional flow modeling using the surveyed bathymetry may help clarify flow magnitudes necessary to completely mobilize these deposits.

- Trench stratigraphy reveals sand grain sizes ranging from $0.2-0.5 \mathrm{~mm}$ deposited during the 2011 flood. There is no discernible trend in vertical sorting of grain size at most locations. This may relate to continued sand supply throughout the course of the flood event or, alternatively, that sand grain size is most strongly coupled to changes in flow rather than sand concentration in Lodore Canyon. Nevertheless, changes in sand grain size can be a bellwether for supply limitation, particularly if high-flow releases become more common.

\section{Discussion}

The geomorphic response to floods portrayed by these data fits with general expectations for the behavior of rivers in debris-flow dominated canyons. Focusing on the data compilation from all reaches in figure 22, high flow events in 1999 and 2011 tend to scour the channel bed $0.5 \mathrm{~m}$ or more, with scour primarily focused on pools, whereas sand deposition in nearshore and eddy zones increases sandbar heights. Between significant floods, such as occurred between 2000 and 2005, sandbars erode and a concurrent infilling of the channel bed occurs. Small, short duration controlled floods in 2005 and 2006 had relatively little effect on the bulk geomorphic character of the system. Analyzing the data in terms of changes in cross-sectional area - a measure of reach-scale mass balance-roughly 2 square meters $\left(\mathrm{m}^{2}\right)$ of area were added to an average cross section in the flood and fluctuating flow zones combined, whereas an average of $35 \mathrm{~m}^{2}$ of sediment was eroded from the bed of a typical cross section (fig. 23). Thus, floods comparable to the 1999 and 2011 events may result in the expansion and building of sandbars, but such floods also export a considerable quantity of sand from the system. This response may have been exacerbated by the very long duration (more than 30 days) of these events, which could cause supply-limited conditions to develop during a flood. 
Although the Colorado River downstream from Glen Canyon Dam is dominantly in a sediment deficit (Grams and others, 2007), the response of Lodore Canyon to Flaming Gorge Dam has been less indicative of sediment deficit conditions as the channel bed has aggraded or remained relatively stable over time. It is likely that tributary inputs from Red and Vermillion Creeks, coupled with supply from the sand-bedded part of the channel through Browns Park (fig. 1), play a large role in buffering the effects of Flaming Gorge Dam. Given that sand storage in pools is replenished during relatively low releases in years between high flows, high antecedent bed sand was likely available in Lodore Canyon in 2011, but this condition may not persist, in particular immediately following a high-flow year. As a result, definitive conclusions of long-term channel response and sediment mass balance are limited by the fact that the 2011 flood is the only time all four study reaches were surveyed following a flow event comparable to 1999. Further, if management decisions drive the system toward more frequent controlled floods, this will increase sediment transport capacity and alter the long-term sediment mass balance.

Although this study provides a good illustration of the processes of channel response in fan-eddy complexes to post-dam floods, it does not necessarily provide a measure of the average response throughout Lodore Canyon. The four reaches included in this study cover about 10 to 15 percent of the channel length of the Green River between Gates of Lodore and Echo Park, and the magnitude of response within

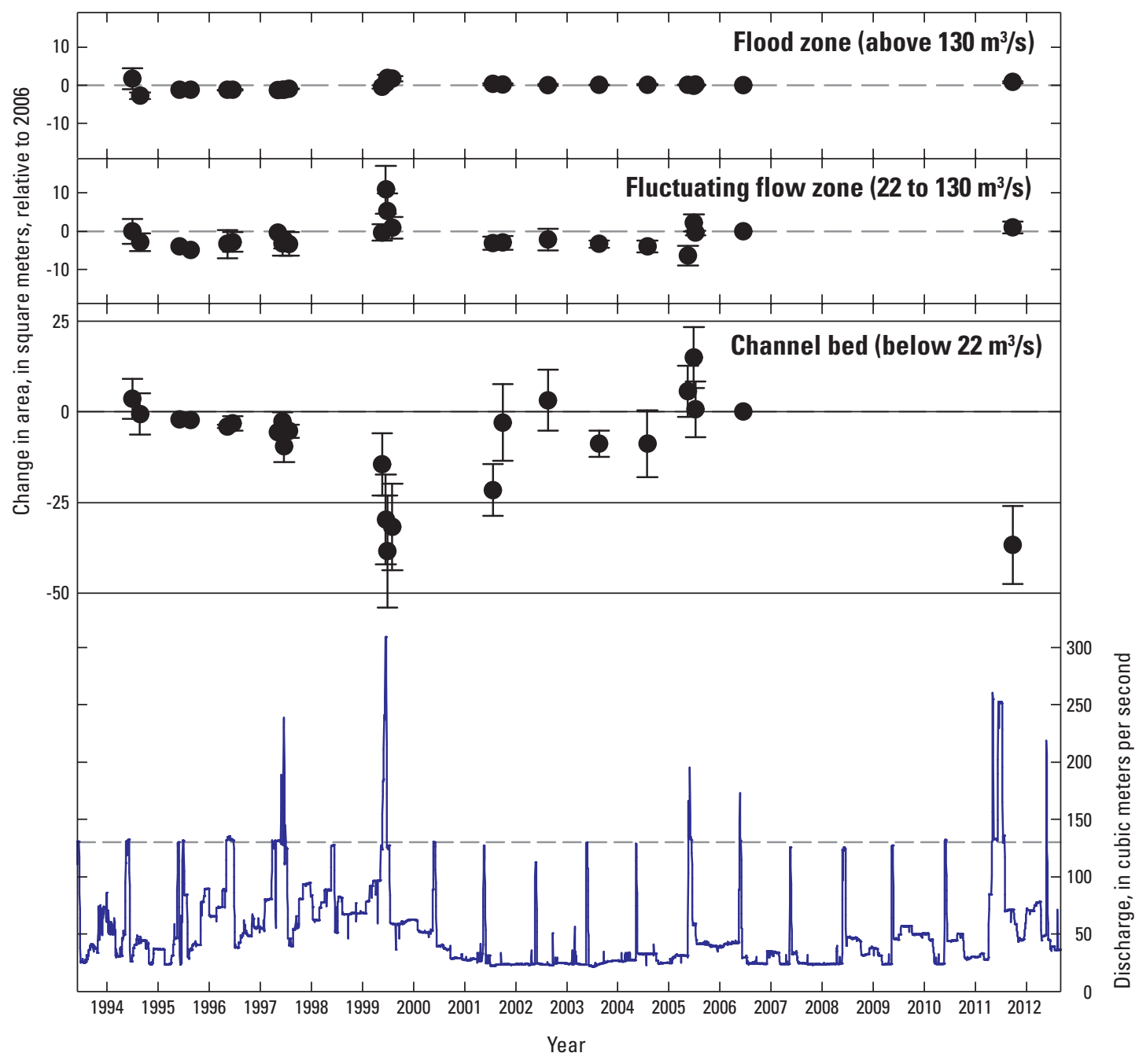

Figure 23. Change in average area for sandbars in the flood zone (top), fluctuating flow zone (middle), and main channel bed (bottom) of the Green River in Canyon of Lodore, Dinosaur National Monument, Colorado and Utah. Points indicate mean for all cross sections in the study area and error bars indicate the standard error of the mean. All plots are at the same scale. The mean daily hydrograph is shown for reference in each figure. $\mathrm{m}^{3} / \mathrm{s}$, cubic meters per second. 
and between study reaches varied considerably. Grams and others (2013) demonstrated that variability in the magnitude of response among fan-eddy complexes downstream from Glen Canyon Dam precluded the use of samples representing of 20 percent or less of the channel to determine trends in reachaverage sediment storage. Thus, although the results of this study do not suggest long-term changes in sediment storage in Lodore Canyon, it is important to recognize that there is large uncertainty, because our sample size is small.

To reduce uncertainty in the sediment budget, multifrequency acoustic-Doppler profilers (ADPs) and Teledyne ISCO automatic pump samplers (Griffiths and others, 2012) have been installed on the Green River at the Gates of Lodore to continuously monitor suspended sediment flux. Combined with similar measurement stations along the Yampa River and the middle Green River just downstream from the monument boundary will allow us to quantify more accurately the fine sediment budget for Lodore Canyon, and for other reaches in Dinosaur National Monument. In future studies, we will be able to link changes in the morphologic sediment budget (that is, changes in storage) directly to changes in the measured sediment mass balance (that is, sediment inputs minus sediment outputs). Thus, sediment-flux measurements used in conjunction with continued monitoring of downstream channel-morphology and sediment-storage changes at the reach scale will contribute to better understanding of the influence of long-term changes in flow and sediment transport on channel and floodplain geomorphology.

\section{Summary}

A controlled flood released from Flaming Gorge Dam in 2011 was the third highest since closure of the dam in 1963. The associated channel changes provided an opportunity to monitor the effects of high flow releases on channel morphology of the Green River. As part of the surveying effort, GNSS and conventional surveying techniques were used to establish a monumented control network and thereby georeference past and future monitoring efforts to a common, high-accuracy datum-NAD83 (NSRS2007). In addition, we collected high-resolution ground-based and bathymetric survey data and established a reach-scale monitoring protocol for geomorphic change detection at four long-term study sites. Study reach topography indicates significant scour of the bed in deep pools downstream from channel constrictions, with new sand deposition on sandbars and channel margins to within $0.2 \mathrm{~m}$ of the stage reached by the 2011 flood. Partial mobility of gravel bars occurred, but entrainment was not sufficient to completely rework the bed surface or remove established tamarisk. Although nearly two decades of research in Lodore Canyon do not indicate a long-term sediment deficit, the data analyzed in this study do indicate that individual floods, such as those that occurred in 1999 and 2011, evacuate fine sediment that accumulates during years without floods; eddy sandbar aggradation occurs during these same floods. Following the 1999 flood, local depletions in sand storage were replenished within 2 to 6 years. Given the uncertainty in the long-term sediment mass balance in Lodore Canyon, continued monitoring of bed, sandbar, and gravel-bar conditions should assess the persistence of flood effects; this is particularly important if controlled floods become more common as a management tool.

\section{Acknowledgments}

The authors would like to thank the National Park Service (NPS) for supporting this study, in particular Tamara Naumann and Mark Wondzell; this work was funded by NPS Interagency Agreement No.: F 1400-11-000. Dave Dean helped in the field and provided important data from Utah State University. Other help in the field was provided by Laura Kennedy, Phaedra Budy and Meagan Polino of Utah State University, Chris Dach and Pete Williams of the NPS, and Ted Kennedy and Ted Melis of the USGS. Rob Ross and Tom Gushue of the USGS provided GIS support in the development of the updated river mile system. Bob Tusso of the USGS compiled much of the documentation data for this report that is available on the GCMRC Web site. Thoughtful reviews by Chuck Podolak and Jim O'Connor helped improve the clarity and content of this report.

\section{References Cited}

Alexander, J., 2007, The timing and magnitude of channel adjustments in the upper Green River below Flaming Gorge Dam in Browns Park and Lodore Canyon, Colorado: An analysis of the pre- and post-dam river using high-resolution dendrogeomorphology and repeat topographic surveys: Logan, Utah, Utah State University, unpublished M.S. thesis, $362 \mathrm{p}$.

Allred, T.M., and Schmidt, J.C., 1999, Channel narrowing by vertical accretion along the Green River near Green River, Utah: Geological Society of America Bulletin, v. 111, no. 12 , p. 1757-1772.

Andrews, E.D., 1986, Downstream effects of Flaming Gorge Dam on the Green River, Colorado and Utah: Geological Society of America Bulletin, v. 97, no. 8, p. 1012-1023.

Belknap, B., and Evans, L.B., 1993, Belknap's Revised Waterproof Dinosaur River Guide: Evergreen, Colo., Westwater Books, 64 p.

Bennion, D., 2009, Statistical and spatial analysis of bathymetric data for the St. Clair River, 1971-2007: U.S. Geological Survey Scientific Investigations Report 2009-5044, 58 p., available at http://pubs.usgs.gov/sir/2009/5044/. 
Birken, A.S., and Cooper, D.J., 2006, Processes of Tamarix invasion and floodplain development along the lower Green River, Utah: Ecological Applications, v. 16, p. 1103-1120.

Buscombe, D., 2013, Transferable wavelet method for grainsize distribution from images of sediment surfaces and thin sections, and other natural granular patterns: Sedimentology, v. 60, no. 7, p. 1709-1732.

Buscombe, D., Rubin, D.M., and Warrick, J.A., 2010, Universal approximation of grain size from images of noncohesive sediment: Journal of Geophysical Research, v. 115, no. F02015, doi:10.1029/2009JF001477.

Cooper, D.J., and Andersen, D.C., 2012, Novel plant communities limit the effects of a managed flood to restore riparian forests along a large regulated river: River Research and Applications, v. 28, no. 2, p. 204-215.

Cooper, D.J., Andersen, D.C., and Chimner, R.A., 2003, Multiple pathways for woody plant establishment on floodplains at local to regional scales: Journal of Ecology, v. 91, p. 182-196.

Dean, D. J., and Schmidt, J. C., 2011, The role of feedback mechanisms in historic channel changes of the lower Rio Grande in the Big Bend region: Geomorphology, v. 126, no. 3, p. 333-349.

DeWine, J.M., and Cooper, D.J., 2007, Effects of river regulation on riparian box elder (Acer negundo) forests in canyons of the upper Colorado River basin, USA: Wetlands, v. 27, no. 2, p. 278-289.

Elliot, C.M., 2002, Relationships between tributary catchments, valley-bottom width, debris-fan area, and mainstem gradient on the Colorado Plateau-A case study in Desolation and Gray Canyons on the Green River: Logan, Utah, Utah State University, unpublished M.S. thesis, 120 p.

Elliot, J.G., and Anders, S.P., 2005, Summary of sediment data from the Yampa River and upper Green River basins, Colorado and Utah, 1993-2002: U.S. Geological Survey Scientific Investigations Report 2004-5242, 40 p., available at http://pubs.usgs.gov/sir/2004/5242/.

Erwin, S.O., Schmidt, J.C., Wheaton, J.M., and Wilcock, P.R., 2012, Closing a sediment budget for a reconfigured reach of the Provo River, Utah, United States: Water Resources Research, v. 48, no. 10, W10512.

Graf, W.L., 1978, Fluvial adjustments to the spread of tamarisk in the Colorado Plateau region: Geological Society of America Bulletin, v. 89, p. 1491-1501.

Graf, W.L., 1980, The effect of dam closure on downstream rapids: Water Resources Research, v. 16, no. 1, p. 129-136.
Grams, P.E., Topping, D.J., Schmidt, J.C., Hazel, J.E., and Kaplinski, M., 2013, Linking morphodynamic response with sediment mass balance on the Colorado River in Marble Canyon-Issues of scale, geomorphic setting, and sampling design: Journal of Geophysical Research-Earth Surface, doi: 10.1002/jgrf.20050.

Grams, P.E. and Schmidt, J.C., 1999, Geomorphology of the Green River in the eastern Uinta Mountains, Dinosaur National Monument, Colorado and Utah, in Miller, A.J., Gupta, A., eds., Varieties of Fluvial Form: Chichester, John Wiley and Sons, Ltd., p. 81-111.

Grams, P.E., and Schmidt, J.C., 2002, Streamflow regulation and multilevel floodplain formation-Channel narrowing on the aggrading Green River in the eastern Uinta Mountains, Colorado and Utah: Geomorphology, v. 44, p. 337- 360.

Grams, P.E., 1997, Geomorphology of the Green River in Dinosaur National Monument: Logan, Utah, Utah State University, unpublished M.S. thesis, $140 \mathrm{p}$.

Grams, P.E., and Schmidt, J.C., 2005, Equilibrium or indeterminate? Where sediment budgets fail-Sediment mass balance and adjustment of channel form, Green River downstream from Flaming Gorge Dam, Utah and Colorado: Geomorphology, v. 71, p. 156-181, doi:10.1016/j. geomorph.2004.10.012.

Grams, P.E., Schmidt, J.C., and Topping, D.J., 2007, The rate and pattern of bed incision and bank adjustment on the Colorado River in Glen Canyon downstream from Glen Canyon Dam, 1956-2000: Geological Society of America Bulletin, v. 119, no. 5-6, p. 556-575, doi:10.1130/ B25969.1.

Grant, G.E., Schmidt, J.C., and Lewis, S.L., 2003, A geological framework for interpreting the downstream effects of dams on rivers, in O'Connor, J.E., and Grant, G.E., eds., A peculiar river-Geology, geomorphology, and hydrology of the Deschutes River, Oregon: Washington, D.C., American Geophysical Union, Water Science Applications, v. 7, p. 203-219.

Griffiths, R.E., Topping, D.J., Andrews, T., Bennett, G.E., Sabol T.A., and Melis, T.S., 2012, Design and maintenance of a network for collecting high-resolution suspendedsediment data at remote locations on rivers, with examples from the Colorado River: U.S. Geological Survey Techniques and Methods, book 8, chapter $\mathrm{C} 2,44$ p., available at http://pubs.usgs.gov/tm/tm8c2/.

Hansen, W.R., 1986, Neogene tectonics and geomorphology of the Eastern Uinta Mountains in Utah, Colorado, and Wyoming: U.S. Geological Survey Professional Paper 1356, $78 \mathrm{p}$. 
Hansen, W.R., Rowley, P.D., and Carrara, P.E., 1983, Geologic map of Dinosaur National Monument and vicinity, Utah and Colorado: U.S. Geological Survey Miscellaneous Investigations Map I-1407, scale 1:50,000.

Hazel, J.E., Jr., Grams, P.E., Schmidt, J.C., and Kaplinski, Matt, 2010, Sandbar response in Marble and Grand Canyons, Arizona, following the 2008 high-flow experiment on the Colorado River: U.S. Geological Survey Scientific Investigations Report 2010-5015, 52 p., available at http://pubs.usgs.gov/sir/2010/5015/.

Hazel, J.E., Jr., Kaplinski, M., Parnell, R.A., Kohl, K., and Schmidt, J.C., 2008, Monitoring fine-grained sediment in the Colorado River ecosystem, Arizona-Control network and conventional survey techniques: U.S. Geological Survey Open-File Report 2008-1276, 15 p., available at http://pubs.usgs.gov/of/2008/1276/.

Howard, A., and Dolan, R., 1981, Geomorphology of the Colorado River in the Grand Canyon: The Journal of Geology, v. 89, no. 3, p. 269-298.

Kaplinski, M., Hazel, J.E., Jr., Parnell, R., Breedlove, M., Kohl, K., and Gonzales, M., 2009, Monitoring finesediment volume in the Colorado River ecosystem, Arizona-Bathymetric survey techniques: U.S. Geological Survey Open-File Report 2009-1207, 33 p., available at http://pubs.usgs.gov/of/2009/1207/.

Larsen, I.J., and Schmidt, J.C., 2003, Geomorphic change at tamarisk removal and control study reaches in the Canyon of Lodore, Green River, Dinosaur National Monument: Bureau of Reclamation and National Park Service, draft report, 25 p.

Larsen, I.J., 2003, From the rim to the river: the geomorphology of debris flows in the Green River canyons: Logan, Utah, Utah State University, unpublished M.S. thesis, 195 p.

Larsen, I.J., Schmidt, J.C., and Martin, J.A., 2003, Debris-fan reworking during low-magnitude floods in the Green River canyons of the eastern Uinta Mountains, Colorado and Utah: Geology, v. 32, no. 4, p. 309-312.

Larson, G.P., 2004, Tamarisk and fluvial geomorphic form in Dinosaur National Monument, Colorado and Utah: Logan, Utah, Utah State University, unpublished M.S. thesis, 129 p.

Leopold, L.B., 1969, The rapids and the pools - Grand Canyon, in the Colorado River Region and John Wesley Powell, U.S. Geological Survey Professional Paper 669, 131 p.

Leopold, L.B., Emmett, W.W., and Myrick, R.M., 1966, Channel and hillslope processes in a semiarid area New Mexico: U.S. Geological Survey Professional Paper 352-G, p. 193-253.
Lyons, J.K., Pucherelli, M.J., and Clark, R.C., 1992, Sediment transport and channel characteristics of a sand-bed portion of the Green River below Flaming Gorge Dam, Utah: Regulated Rivers - Research and Management, v. 7, p. 219-232.

Magirl, C.S., Breedlove, M.J., Webb, R.H., Griffiths, P.G., 2008, Modeling water-surface elevations and virtual shorelines for the Colorado River in Grand Canyon, Arizona: U.S. Geological Survey Scientific Investigations Report 2008-5075, 32 p., available at http://pubs.usgs.gov/sir/2008/5075/.

Manners, R.B., Schmidt, J.C., Scott, M.L., Scott, J.A., and Neale, C.M.U., 2011, Investigate floodplain processes and riparian ecosystem linkages on the Yampa River and on the middle Green River in Dinosaur National Monument, Moffat County, Colorado, and Uintah County ,Utah: Final Report to the Colorado Plateau Cooperative Ecosystem Studies Unit and Dinosaur National Monument, 25 p.

Martin, J.A., 2000, Debris-flow activity in Canyon of Lodore, Colorado-Implications for debris-fan formation and evolution: Logan, Utah, Utah State University, unpublished M.S. thesis, $142 \mathrm{p}$.

Martin, J.A., Grams, P.E., Kammerer, M.T., and Schmidt, J.C., 1998, Sediment transport and channel response of the Green River in the Canyon of Lodore between 1995-1997, including measurements during high flows, Dinosaur National Monument, Colorado: Bureau of Reclamation and National Park Service, draft final report, 190 p.

McCullagh, M.J., 1988, Terrain and surface modeling systems: theory and practice: Photogrammetric Record, v. 12, p. 747-779.

Melis, T.S., 1997, Geomorphology of debris flows and alluvial fans in Grand Canyon National Park and their influence on the Colorado River below Glen Canyon Dam, Arizona: Tucson, Arizona, University of Arizona, Ph.D. dissertation, 490 p.

Melis, T.S., ed., 2011, Effects of three high-flow experiments on the Colorado River ecosystem downstream from Glen Canyon Dam, Arizona: U.S. Geological Survey Circular 1366, 147 p., available at http://pubs.usgs.gov/circ/1366/.

Merritt, D.M., and Cooper, D.J., 2000, Riparian vegetation and channel change in response to river regulation-A comparative study of regulated and unregulated streams in the Green River Basin, USA: Regulated Rivers_-Research and Management, v. 16, p. 543-564.

Muth, R.T., Crist, L.W., LaGory, K.E., Hayse, J.W., Bestgen, K.R., Ryan, T.P., Lyons, J.K., and Valdez, R.A., 2000, Flow and Temperature Recommendations for Endangered Fishes in the Green River Downstream of Flaming Gorge Dam: Upper Colorado River Endangered Fish Recovery Program Project FG-53, final report, 343 p. 
Pitlick, J., 2006, Channel monitoring to evaluate geomorphic changes on the main stem of the Colorado River: Recovery Program Project Number 85A, U.S. Fish and Wildlife Service, final report, $54 \mathrm{p}$.

Rubin, D.M., 2004, A simple autocorrelation algorithm for determining grain size from digital images of sediment: Journal of Sedimentary Research, v. 74, p. 160-165.

Rubin, D.M., and Topping, D.J., 2001, Quantifying the relative importance of flow regulation and grain size regulation of suspended-sediment transport $\alpha$ and tracking changes in grain size of bed sediment $\beta$ : Water Resources Research, v. 37 , no. 1 , p. 133-146.

Rubin, D.M., Chezar, H., Harney, J.N., Topping, D.J., Melis, T.S., and Sherwood, C.R., 2007, Underwater microscope for measuring spatial and temporal changes in bedsediment grain size, in Hartmann, D., and Flemming, B.W., eds., From Particle Size to Sediment Dynamics: Sedimentary Geology, v. 202, p. 402-408.

Rubin, D.M., Nelson, J.M., and Topping, D.J., 1998, Relation of inversely graded deposits to suspended-sediment grainsize evolution during the 1996 flood experiment in Grand Canyon: Geology, v. 26, no. 2, p. 99-102.

Rubin, D.M., Schmidt, J.C., and Moore, J.N., 1990, Origin, structure, and evolution of a reattachment bar, Colorado River, Grand Canyon, Arizona: Journal of Sedimentary Petrology, v. 60, no. 6, p. 982-991.

Schmidt, J.C., and Grams, P.E., 2011, The high flowsPhysical science results, chapter 3 of Melis, T.S., ed., Effects of three high-flow experiments on the Colorado River ecosystem downstream from Glen Canyon Dam, Arizona: U.S. Geological Survey Circular 1366, 147 p., available at http://pubs.usgs.gov/circ/1366/.

Schmidt, J.C., 1990, Recirculating flow and sedimentation in the Colorado River in Grand Canyon, Arizona: The Journal of Geology, v. 98, no. 5, p. 709-724.

Schmidt, J.C., and Rubin, D.M., 1995, Regulated streamflow, fine-grained deposits, and effective discharge in canyons with abundant debris fans, in Costa, J.E., Miller, A.J., Potter, K.W., and Wilcock, P.R., eds., Natural and anthropogenic influences in fluvial geomorphology: Washington, D.C., American Geophysical Union, Geophysical Monograph Series, v. 89, p. 177-194.

Schmidt, J.C., and Wilcock, P.R., 2008, Metrics for assessing the downstream effects of dams: Water Resources Research, v. 44, no. W04404, p. 1-19, doi:10.1029/2006WR005092.

Schmidt, J.C., Grams, P.E., and Webb, R.H., 1995, Comparison of the magnitude of erosion along two large regulated rivers: Water Resources Bulletin, v. 31, p. 617-631.
Schmidt, J.C., Topping, D.J., Grams, P.E., and Hazel, J.E., 2004, System-wide changes in the distribution of fine sediment in the Colorado River corridor between Glen Canyon Dam and Bright Angel Creek, Arizona_-Final report: Logan, Utah, Utah State University, submitted to U.S. Geological Survey, Grand Canyon Monitoring and Research Center, cooperative agreement no. 1425-98-FC-40-22640, 107 p.

Sibson, R., 1981, A brief description of natural neighbor interpolation, chapter 2 of Barnet, V., ed., Interpolating multivariate data: New York, John Wiley \& Sons, p. 21-36.

Topping, D.J., Rubin, D.M., and Melis, T.S., 2007, Coupled changes in sand grain size and sand transport driven by changes in the upstream supply of sand in the Colorado River; relative importance of changes in bed-sand grain size and bed-sand area: Sedimentary Geology, v. 202, p. 538-561, doi: 10.1016/j.sedgeo.2007.03.016.

Topping, D.J., Rubin, D.M., and Schmidt, J.C., 2005, Regulation of sand transport in the Colorado River by changes in the surface grain size of eddy sandbars over multi-year timescales: Sedimentology, v. 52, p. 1133-1153.

Topping, D.J., Rubin, D.M., Grams, P.E., Griffiths, R.E., Sabol, T.A., Voichick, Nicholas, Tusso, R.B., Vanaman, K.M., and McDonald, R.R., 2010, Sediment transport during three controlled-flood experiments on the Colorado River downstream from Glen Canyon Dam, with implications for eddy-sandbar deposition in Grand Canyon National Park: U.S. Geological Survey Open-File Report 2010-1128, 111 p., available at http://pubs.usgs.gov/of/2010/1128/.

Vincent, K.R., and Andrews, E.D., 2008, Depositional settings of sand beaches along whitewater rivers: River Research and Applications, v. 24, p. 771-788.

Wheaton, J.M., Brasington, J., Darby, S.E., and Sear, D., 2010, Accounting for uncertainty in DEMs from repeat topographic surveys - Improved sediment budgets: Earth Surface Processes and Landforms, v. 35, no. 2, p. 136-156, doi: 10.1002/esp.1886.

Wheaton, J.M., Garrard, C., Volk, C., Whitehead, K., and Bouwes, N., 2012, A simple, interactive GIS tool for transforming assumed total station surveys to real world coordinates - The CHaMP Transformation Tool: Computers and Geosciences, v. 42, p. 28-36, doi: 10.1016/j. cageo.2012.02.003.

Williams, G.P., and Wolman, M.G., 1984, Downstream effects of dams on alluvial rivers: U.S. Geological Survey Professional Paper 1286, 83 p.

Wright, S.A., and Kaplinski, M., 2011, Flow structures and sandbar dynamics in a canyon river during a controlled flood, Colorado River, Arizona: Journal of Geophysical Research, v. 116, no. F1, F01019, doi: 10.1029/2009JF001442. 


\section{Appendixes}




\section{Appendix 1. Surficial Geology and Geomorphic Surfaces Mapped for the Study Reaches}

Appendix 1 discusses surficial geology and geomorphic surfaces mapped for the study reaches in the Canyon of Lodore, Dinosaur National Monument, Colorado and Utah.

\section{Methods}

The surficial geologic maps were interpreted from 1:5,000 aerial photographs taken in 1993 at a discharge of roughly $33 \mathrm{~m}^{3} / \mathrm{s}$ and digitized into GIS by Grams (1997). The photo-interpreted maps were field checked and transferred to a 1:12,000 scale topographic base map. Grams (1997) estimated the error in the final map products as $\pm 5 \mathrm{~m}$ based on mapping stable areas (for example, Quaternary alluvium) unlikely to have changed over the past 100 years using a comparison of 1938 and 1993 air photos. These maps include information on the depositional environment, grain size, and geomorphic surface levels described below. We translated the unrectified GIS layers from a local coordinate system to the NAD83 Colorado State Plane (NSRS 2007) north zone 0501 grid using the CHaMP transformation tool (Wheaton and others, 2012). More details on the mapping techniques and units can be found in Grams (1997) and Grams and Schmidt (2002).

\section{Map Unit Descriptions}

Below is a summary of the map units in the Canyon of Lodore originally mapped by Grams (1997).

\section{Primary Depositional Environments}

These descriptions refer to the sedimentary depositional environment of the mapped deposits in the Canyon of Lodore. See figures 1-1 through 1-4 for maps of primary depositional environments.

\section{Talus}

Talus is an accumulation of broken rock fragments at the base of a cliff derived from mass-wasting processes, such as rock fall, and forming a slope near the angle of repose. Talus deposits are poorly sorted but typically include large matrix forming boulders. These deposits differ from debris fans in that they are not associated with tributary channels, but are generally found in association with cliffs or over-steepened hillslopes.

\section{Debris Fan}

Debris fans are accumulations of poorly-sorted sediment, ranging from clay to boulders, deposited from one or many debris flows at the mouths of tributary drainages. Debris fan morphology is a function of tributary basin size, local geology, debris flow frequency, and reworking by the mainstem river. Debris fans tend to restrict the main river channel, often resulting in the formation of rapids and upstream ponded backwaters, and form the centerpiece of fan-eddy complexes that dominate the geomorphology of many canyon-bound river systems (Schmidt and Rubin, 1995).

\section{Channel Margin}

Channel margin deposits are narrow (1-5 m) strips of alluvium as much as several channel widths long that usually occur in relatively straight reaches with uniform flow; although they can also occur along banks near debris fans or adjacent to point bars where the main channel turns abruptly (Grams and Schmidt, 1999). Channel-margin deposits are typically fine-grained, but can include gravel, and represent areas of the river system that are currently, or were historically, inundated by periodic high flows or associated with local channel migration.

\section{Gravel Bar}

Gravel bars are alluvial sediment deposits characterized by gravel and cobbles but can include both finer and coarser material. In debris-fan dominated canyon settings, gravel bars are often found in the flow expansion zones downstream of debris fans and typically contain clasts locally derived from these fans (Grams and Schmidt, 1999). Gravel bars commonly form attached to one bank adjacent to higher elevation channel margin deposits and, in the post-dam environment, can be capped by more recent fine sediment deposition. Gravel bars may also form as point bars or mid-channel bars and are not always associated with debris fans, instead reflecting local hydraulic conditions often in association with wider alluvial reaches.

\section{Eddy Bar}

Eddy sandbars form below flow constrictions in zones of recirculation and represent the dominant zone of fine sediment deposition in fan-eddy complexes. Debris fans are the main cause of channel constriction, but talus, bedrock, or gravel bars may also constrict flow and cause the formation of eddy bars (Grams and Schmidt, 1999). Eddy bars form as a result of flow expansion and recirculation downstream of channel constrictions, such that suspended sediment contained in the high velocity zone is drawn toward lower velocity zones near the channel banks where it falls from suspension. Eddy bars are dominated by sand and show the stratigraphic signature of flow stagnation, wave-swash, and rotary flow indicated by planar deposits, climbing ripples, and migrating dunes (Schmidt and Rubin, 1995). In some cases, eddy bars are partially separated from the bank by a return channel of higher velocity upstream directed flow in the flow recirculation zone. 


\section{Separation Bar}

Separation bars are a subtype of eddy sandbars. Separation bars form near the flow separation point and mantle the debris fan (Schmidt and Rubin, 1995). Separation bars are not always distinguishable from reattachment bars (see below), and are typically associated with a secondary eddy and finer grained sediment than reattachment bars (Schmidt, 1990). Along the Green River in Lodore Canyon, separation bars and reattachment bars often merge to form undifferentiated eddy bars (Grams and Schmidt, 1999).

\section{Reattachment Bar}

Reattachment bars are a sub-type of eddy sandbars. Reattachment bars form near the center of the primary eddy in flow recirculation zones, often projecting upstream in the form of a spit (Schmidt, 1990). Reattachment bars form downstream from separation bars and are disconnected from them due to secondary, upstream directed flow in the recirculation zone. In some cases, they may be connected to and indistinguishable from separation bars; in these scenarios they are simply labeled as eddy bars. The size, shape, and location of reattachment bars varies as a function of discharge and sediment concentration and often exhibit a fining upward sequence as flow becomes restricted over the bar crest (Rubin and others, 1990).

\section{Geomorphic Surface Levels}

These descriptions refer to the geomorphic surface levels that are discriminated by elevation and vegetation type in the Canyon of Lodore. See figures 1-1 through 1-4 for maps of geomorphic surface levels.

\section{Cottonwood-Box Elder Terrace}

The cottonwood-box elder terrace is named for the Fremont cottonwood (Populus fremontii) and box elder (Acer negundo) trees that are abundant on its surface, although other trees may occupy this surface as well (Martin and others, 1998). The majority of box elder on this surface are mature or senescent and as much as 80-100 years old with no evidence of recruitment under the post-dam flow hydrology (DeWine and Cooper, 2007). This surface represents the highest elevation alluvial surface mapped for this study, likely represents deposits from pre-dam floods with recurrence intervals of approximately 25 years, and was last inundated in 1957 (Grams and Schmidt, 2002). Stratigraphic analyses of this terrace shows distinct horizontal bedding $2-3 \mathrm{~m}$ thick composed of fine to medium sand (Grams and Schmidt, 2002). In Lodore Canyon, the terrace surface is approximately $3 \mathrm{~m}$ above the baseflow water level (Martin and others, 1998) and is no longer inundated by flows characteristic of the post-dam hydrology.

\section{Intermediate Bench}

The intermediate bench occurs inset into and at a lower elevation than the cottonwood-box elder terrace, and is dominated by tamarisk (Tamarix ramosissima) with lesser willow (Salix sp.), box-elder, and cottonwood. (Grams and Schmidt, 2002). Thickness of this deposit ranges from $0.5-1.5 \mathrm{~m}$ and overlies units of the cottonwood-box elder terrace (Martin and others, 1998). This bench lies roughly 1 meter above the baseflow level in Lodore Canyon and is composed of fine to medium sand with thin surface organic layers (Martin and others, 1998; Grams and Schmidt, 2002). This surface was likely inundated by typical 1-to-2 year flood discharges prior to dam construction but is only inundated during relative rare dam bypass flow releases under the current hydrologic regime (Grams and Schmidt, 2002). The intermediate bench has aggraded during the post-dam period associated with these high flow releases, which has had the effect of decreasing its connectivity to more typical flows of the Green River in Lodore Canyon (Alexander, 2007).

\section{Floodplain}

Floodplain here refers to the post-dam floodplain, a level that is inundated annually by flow releases from Flaming Gorge Reservoir. The surface is less than a meter above baseflow elevation and is dominated by young woody vegetation such as tamarisk, willow, and cottonwood (Martin and others, 1998). The post-dam floodplain consists of fine to medium sand, is inset into the intermediate bench along channel margins and eddies, and overlies mid-channel gravel bars. On gravel bars that are rarely mobilized, the post-dam floodplain is characterized by a veneer of fine-grained sediment with some immature vegetation establishment (Grams, 1997).

\section{Active Channel}

Active channel deposits are alluvial deposits that are mobilized frequently enough to prevent the establishment of perennial vegetation, consisting of bare sand, gravel, or debris; these deposits may include side channels lacking vegetation (Grams, 1997). 


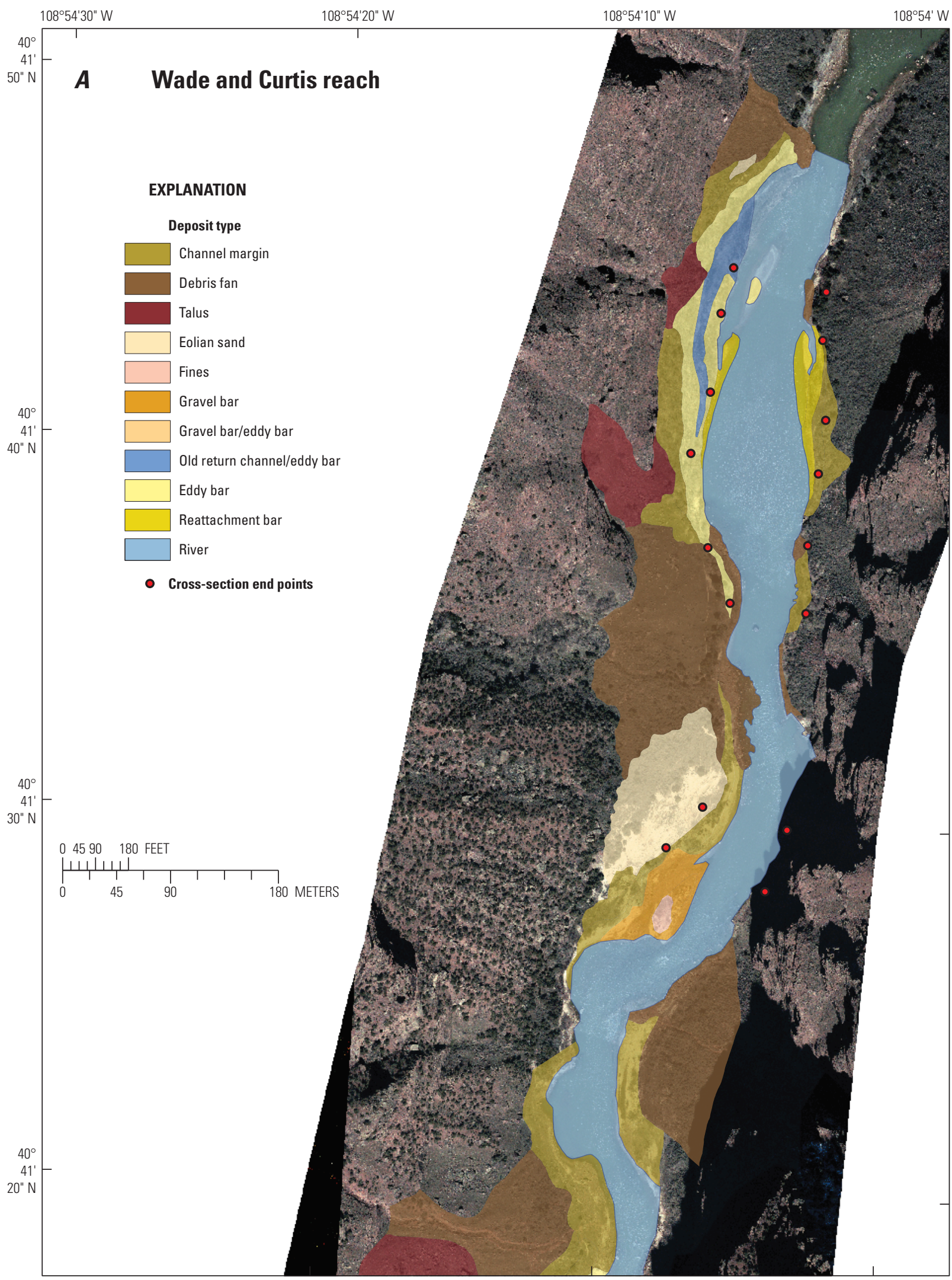

Figure 1-1. Primary depositional environments $(A)$ and geomorphic surface levels $(B)$ for the Wade and Curtis reach, Canyon of Lodore, Dinosaur National Monument, Colorado and Utah. 


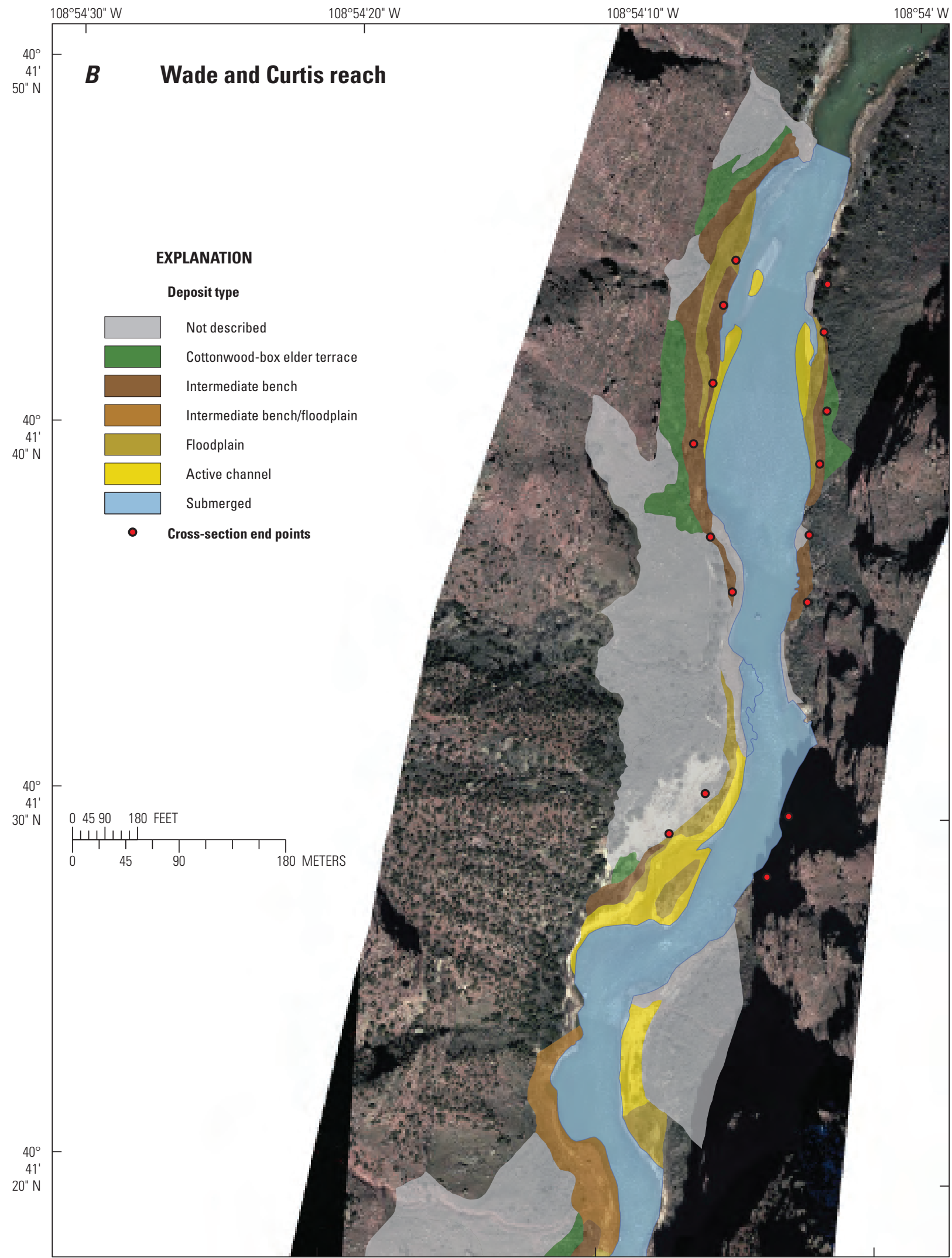

Figure 1-1. Primary depositional environments $(A)$ and geomorphic surface levels $(B)$ for the Wade and Curtis reach, Canyon of Lodore, Dinosaur National Monument, Colorado and Utah. — Continued 


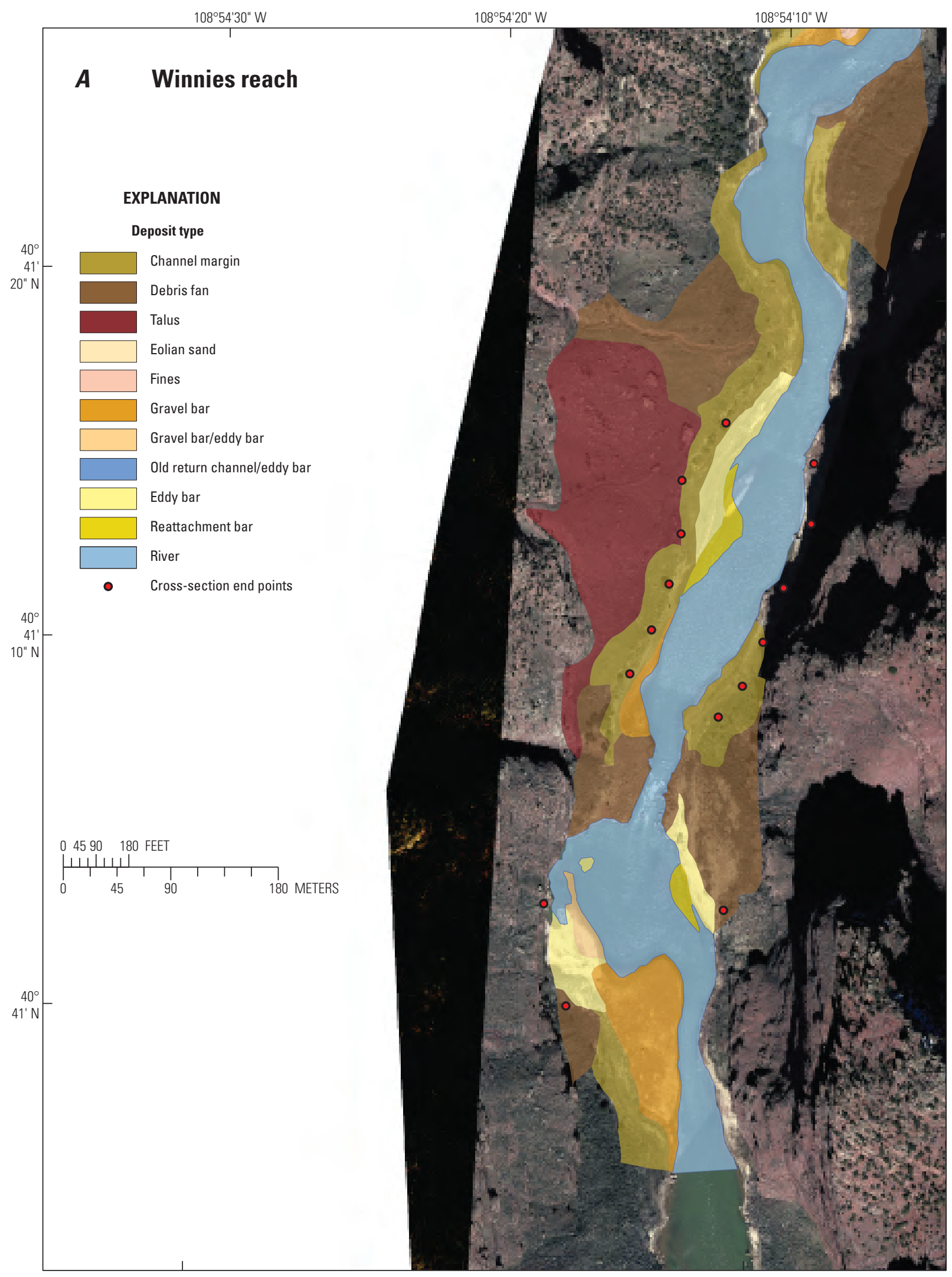

Figure 1-2. Primary depositional environments $(A)$ and geomorphic surface levels $(B)$ for the Winnies reach, Canyon of Lodore, Dinosaur National Monument, Colorado and Utah. 


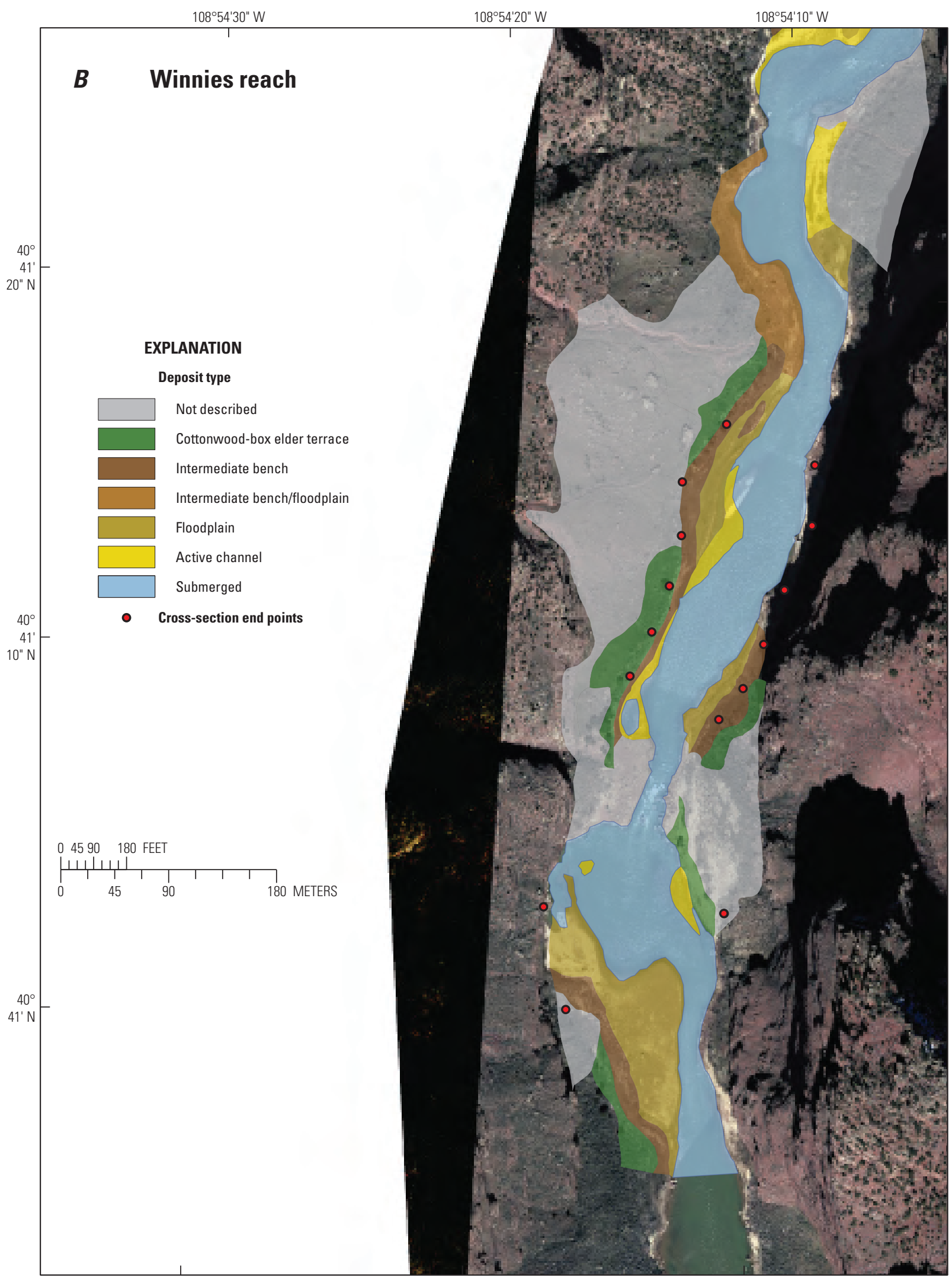

Figure 1-2. Primary depositional environments $(A)$ and geomorphic surface levels $(B)$ for the Winnies reach, Canyon of Lodore, Dinosaur National Monument, Colorado and Utah. —Continued 


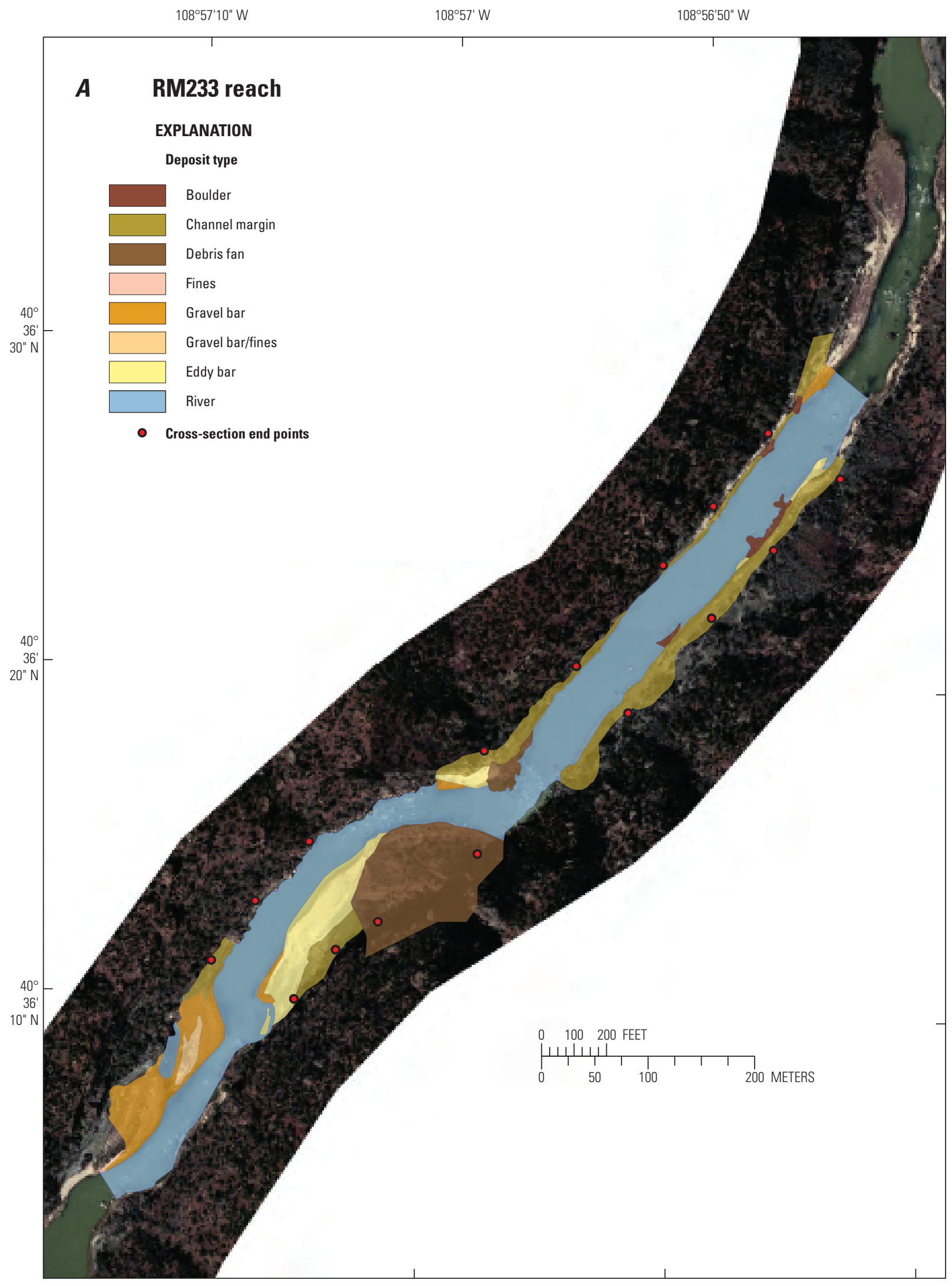

Figure 1-3. Primary depositional environments $(A)$ and geomorphic surface levels $(B)$ for the RM233 reach, Canyon of Lodore, Dinosaur National Monument, Colorado and Utah. 


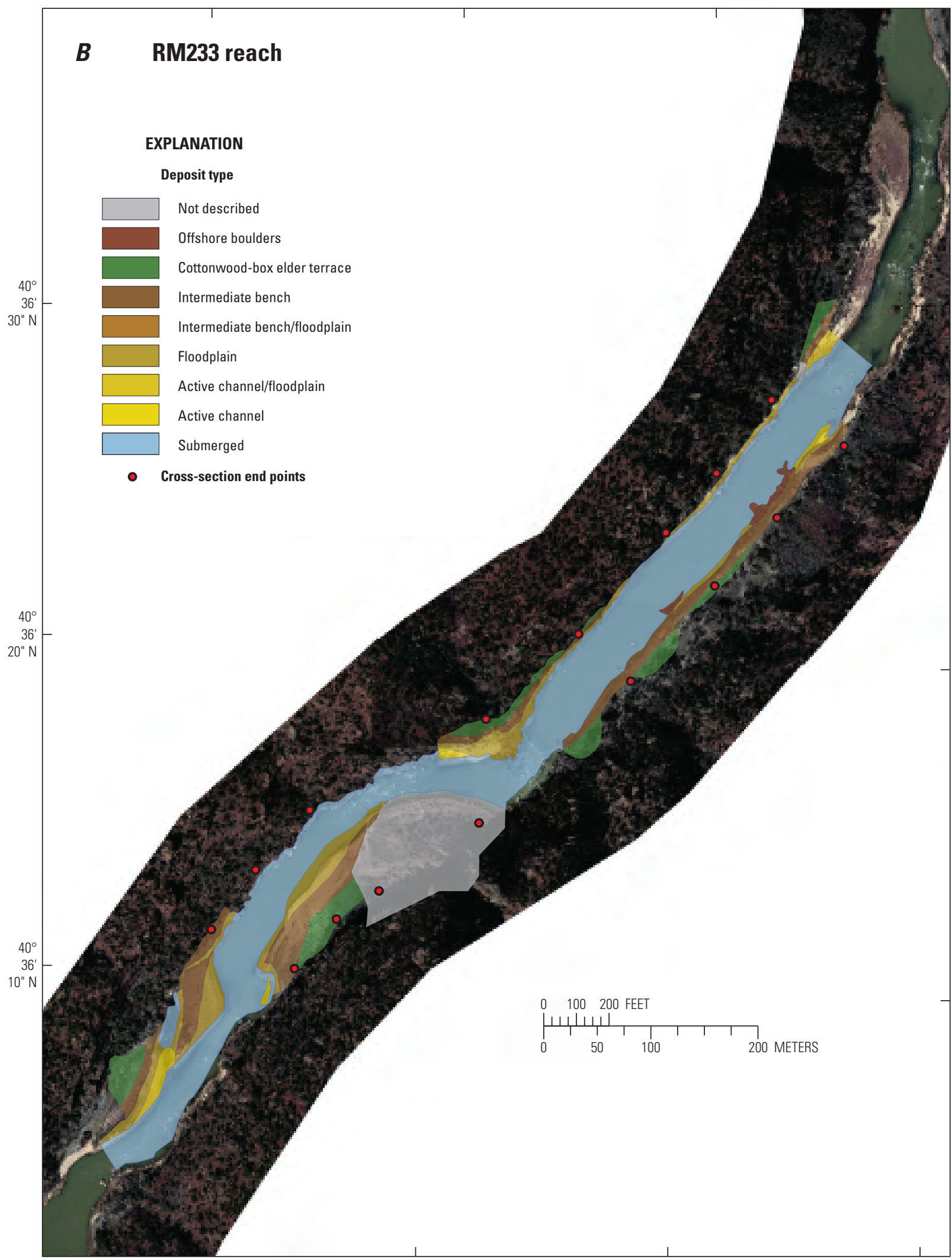

Figure 1-3. Primary depositional environments $(A)$ and geomorphic surface levels $(B)$ for the RM233 reach, Canyon of Lodore, Dinosaur National Monument, Colorado and Utah. —Continued 


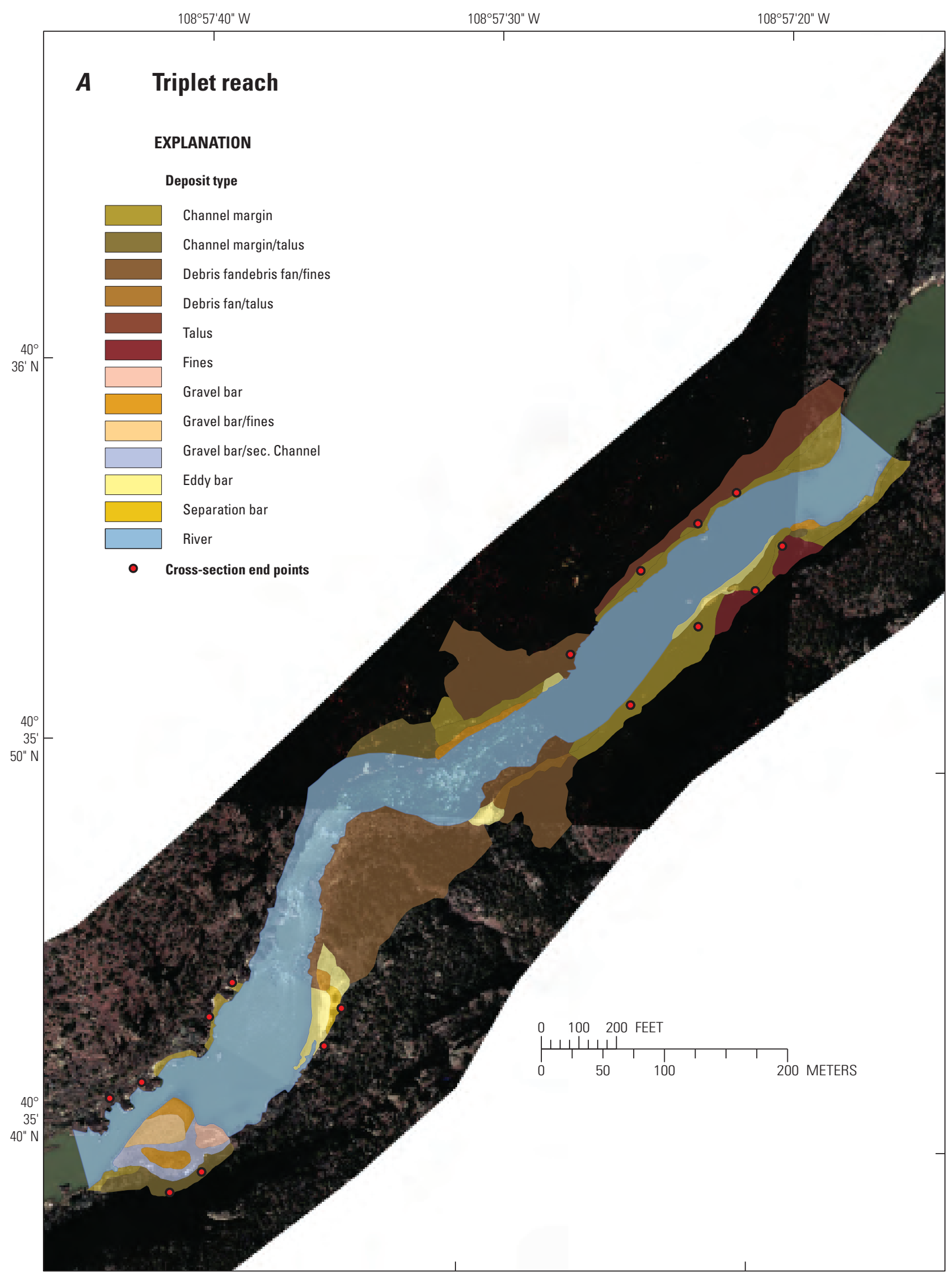

Figure 1-4. Primary depositional environments $(A)$ and geomorphic surface levels $(B)$ for the Triplet reach, Canyon of Lodore, Dinosaur National Monument, Colorado and Utah. 


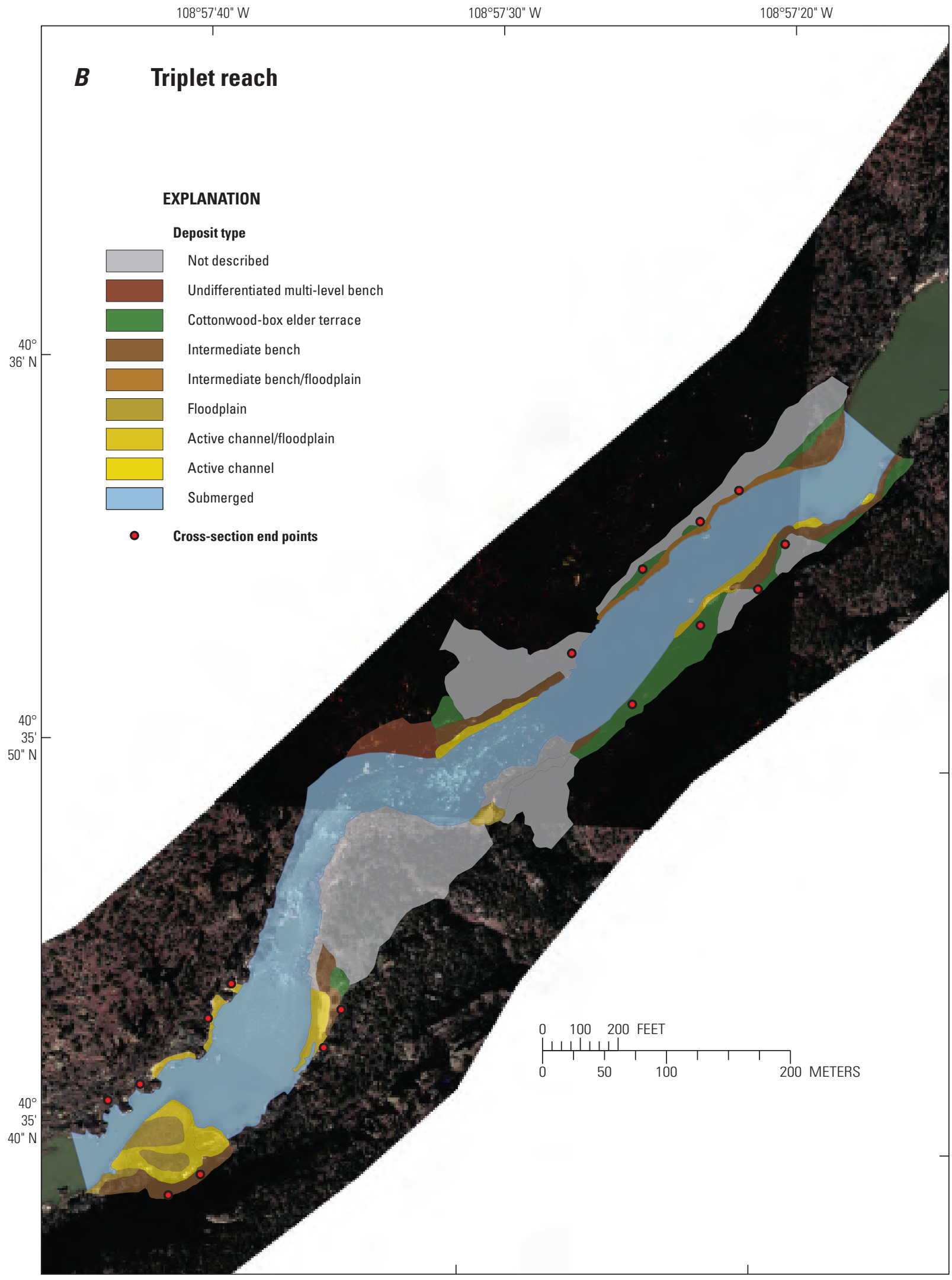

Figure 1-4. Primary depositional environments $(A)$ and geomorphic surface levels $(B)$ for the Triplet reach, Canyon of Lodore, Dinosaur National Monument, Colorado and Utah. 


\section{Appendix 2. Trench Stratigraphy Data}

This appendix is a .xlsx table and includes the site description, location coordinates, grain size, and sedimentology of the stratigraphic trenches described in the text for Canyon of Lodore, Dinosaur National Monument, Colorado and Utah. It is only available online at http://pubs.usgs.gov/sir/2014/5022/.

\section{Appendix 3. 2011 Cross-Section Plots}

Appendix 3 consists of four long-term monitoring cross-sections extracted from the 2011 digital terrain models (DTMs) for the Wade and Curtis, Winnies, RM233, and Triplet reaches, Canyon of Lodore, Dinosaur National Monument, Colorado and Utah (figs. 3-1 through 3-4). 

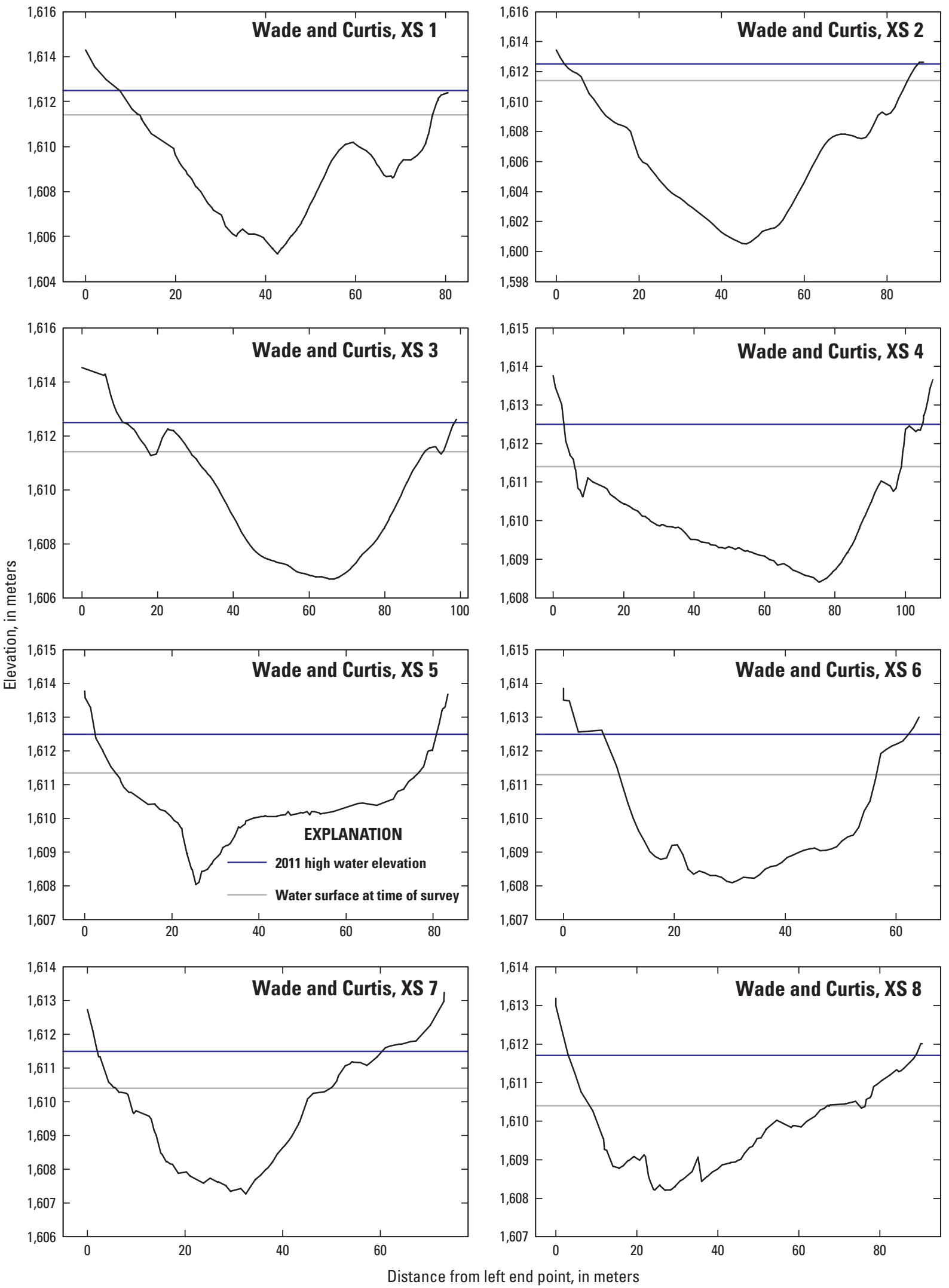

Figure 3-1 Long-term monitoring cross-sections extracted from the 2011 digital terrain models (DTMs) for the Wade and Curtis reach, Canyon of Lodore, Dinosaur National Monument, Colorado and Utah. 

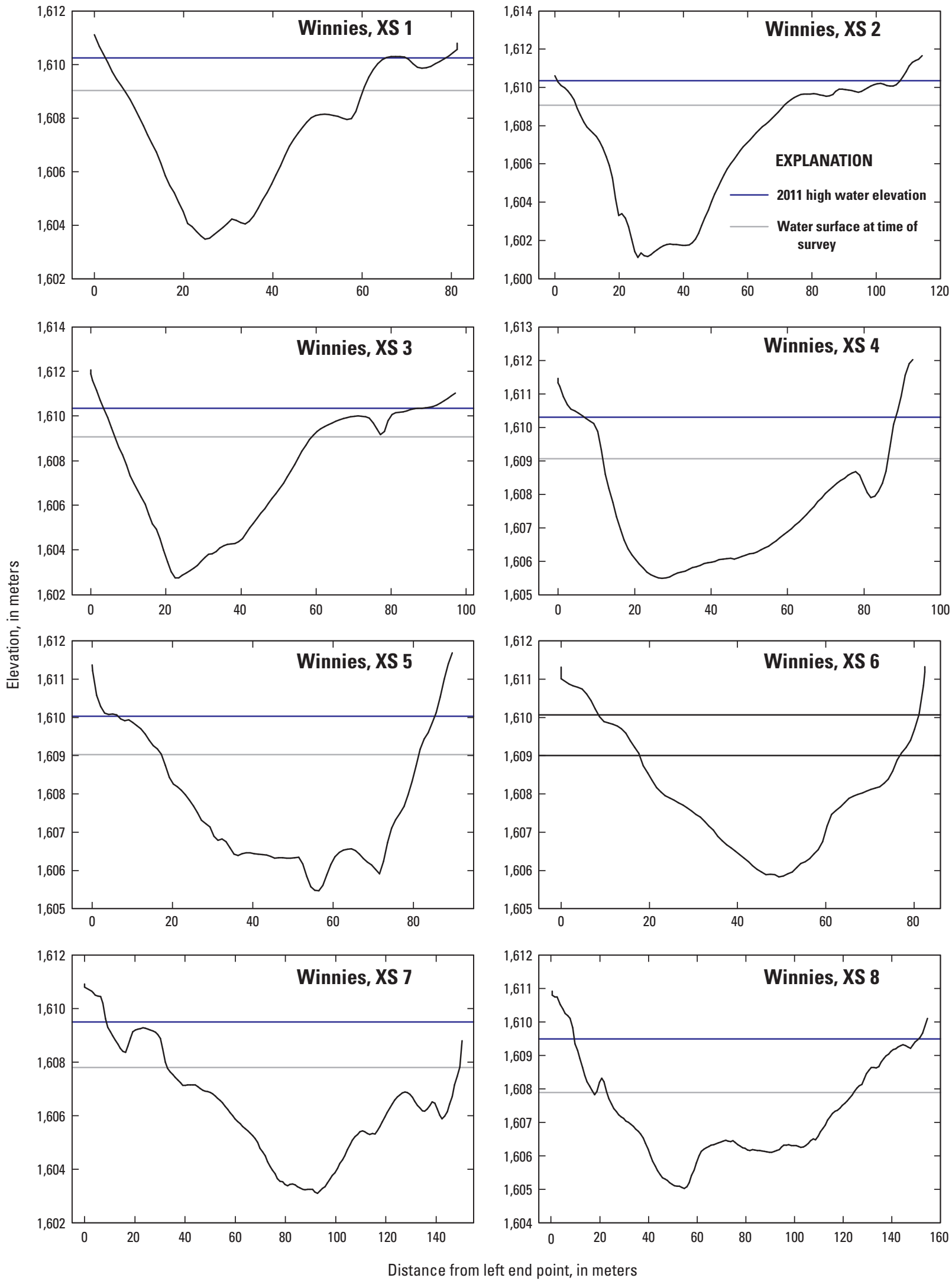

Figure 3-2 Long-term monitoring cross-sections extracted from the 2011 digital terrain models (DTMs) for the Winnies reach, Canyon of Lodore, Dinosaur National Monument, Colorado and Utah. 

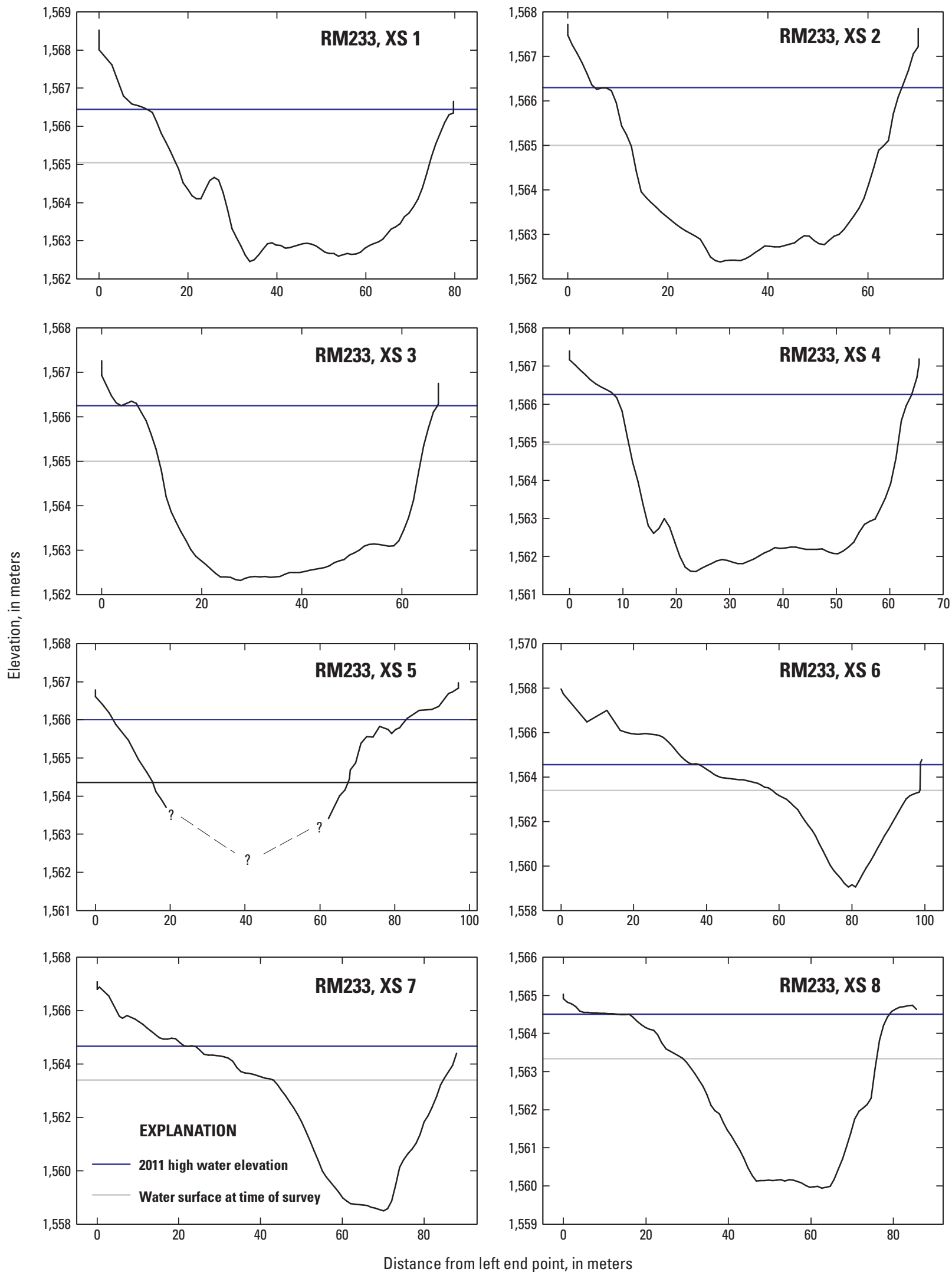

Figure 3-3 Long-term monitoring cross-sections extracted from the 2011 digital terrain models (DTMs) for the RM233 reach, Canyon of Lodore, Dinosaur National Monument, Colorado and Utah. 

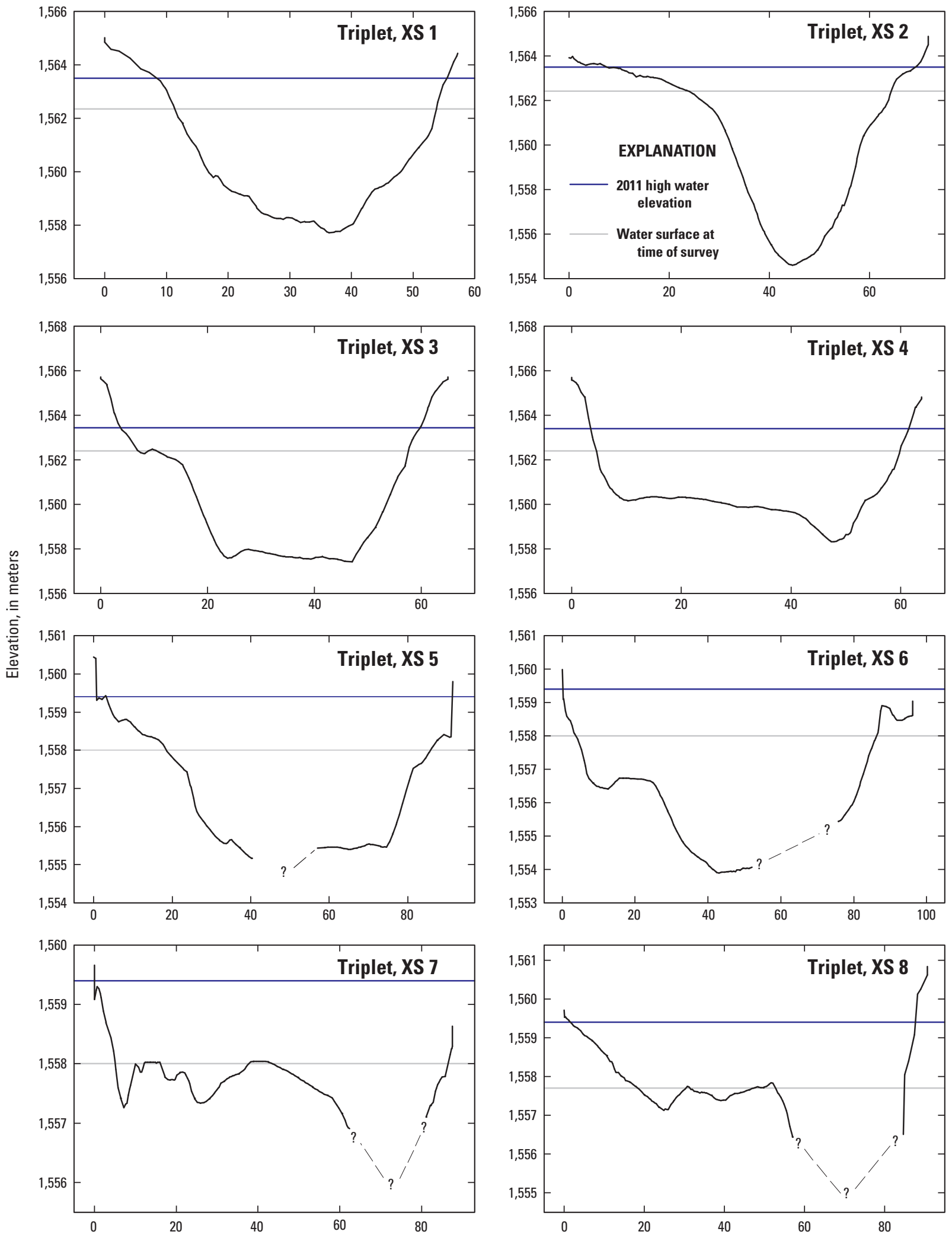

Distance from left end point, in meters

Figure 3-4 Long-term monitoring cross-sections extracted from the 2011 digital terrain models (DTMs) for the Triplet reach, Canyon of Lodore, Dinosaur National Monument, Colorado and Utah. 
Menlo Park Publishing Service Center, California

Manuscript approved for publication January 28, 2014

Edited by James W. Hendley II

Layout and design by Ronald S. Spencer 
